1990

\title{
Haven or Hell? Inside Lorton Central Prison: Experiences of Punishment Justified
}

Robert Blecker

New York Law School, robert.blecker@nyls.edu

Follow this and additional works at: http://digitalcommons.nyls.edu/fac_articles_chapters

Part of the Criminal Law Commons, and the Law Enforcement and Corrections Commons

\section{Recommended Citation}

Stanford Law Review, Vol. 42, Issue 5 (May 1990), pp. 1149-1250

This Article is brought to you for free and open access by the Faculty Scholarship at DigitalCommons@NYLS. It has been accepted for inclusion in Articles \& Chapters by an authorized administrator of DigitalCommons@NYLS. 


\title{
Haven or Hell? Inside Lorton Central Prison: Experiences of Punishment Justified
}

\author{
Robert Blecker*
}

\section{INTRODUCTION}

The great challenge of crime and its punishment has produced solutions through the ages, ranging from furiously torturing the body of the evil wrongdoer, to compassionately ministering to the soul of the poor wretch. Moved by the gravity of the problem, anguished reformers have given the grand pendulum momentum to swing back and forth over familiar paths, successively claimed as new wisdom but anchored always by a fixed point: the abject failure of the institution of punishment.

By 1984 , having long since concluded that its own system of punishment was not working, Congress had rejected rehabilitation as an outmoded philosophy, abolished parole, and established the United States Sentencing Commission to fix sentences for a vast array of federal crimes, based largely on a philosophy of giving each criminal his just deserts. ${ }^{1}$ On January 18, 1989, rejecting separation-of-powers objections, the United States Supreme Court sustained the Legislature's right to implement its new penal philosophy by delegating power to the Commission. ${ }^{2}$ In the next forty-eight hours, a half-dozen people fell victim to homicide within five miles of the Supreme Court building. ${ }^{3}$ On January 20, 1989, while hotel ballroom parties celebrated the inauguration of a new Administration which proclaimed a "kinder gentler

* 1990 by Robert Blecker. Professor of Law, New York Law School; J.D., Harvard Law School; B.A., Tufts University; Harvard Fellow in Law and Humanities.

This study was made possible by Professor Philip Heymann who initiated it, Director Walter Ridley who authorized it, Administrator David Roach and the prison staff who cooperated thoroughly, and most importantly the prisoners of Lorton Central, many quoted herein by name, whose honesty is this article's core. Professor Lloy'd Weinreb critiqued an early draft, and my colleagues Professors B. James George, Randolph Jonakait, and Dean James Simon offered helpful suggestions early on. Stephen Peduto, Celeste Whyte and Lurlyn Winchester also rendered assistance. Throughout, Professor Marcia Zaroff not only sacrificed as an author's spouse, but also tenaciously critiqued and tirelessly edited every draft.

1. See Sentencing Reform Act of 1984, Pub. L. No. 98-473, 98 Stat. 1987 (1984).

2. Mistretta v. United States, 109 S. Ct. 647 (1989).

3. Telephone interview with the D.C. Office of Criminal Justice, Plans, and Analysis (Oct. 1989). January 1989 was a most bloody month, even for Washington, D.C., with 53 homicides. 
nation" and "a thousand points of light," inside Lorton Central Prison, Washington, D.C.'s main penitentiary, a power failure sparked prisoners to burn down the prison's administration building.

During the next several months, the crack epidemic, which had fueled a wild explosion of violent crime in the inner cities, continued to ravage the streets surrounding the nation's government. Washington, D.C. was dubbed the "murder capital of the United States," and President Bush launched a comprehensive "war on drugs." 4 As the decade closed and the death toll mounted, the polls confirmed it: America was once again obsessed with its chronic crisis ${ }^{5}$-violent street crime.

\section{A. The Problem: Justifying Punishment}

Why and how should we punish these criminals? A fearful and furious citizen may demand: "First, get them off the streets; keep them away from us. Make them suffer: They deserve it. Teach them a lesson they will not forget. And let their pain and suffering be an example to others. Maybe then, having been punished, someday, somehow, these criminals will feel remorse, change their attitudes, and productively reintegrate into society." Drawing upon sentiments and concepts implicit in the Bible and the works of Plato, Hobbes, Beccaria, Kant, Bentham, and a host of contemporary commentators, the citizen urges that punishment serve as incapacitation, retribution, general deterrence, specific deterrence, and rehabilitation.

The precise definition of each concept differs with each advocate, antagonist, or analyst. Essentially, however, incapacitation is rendering harmless to society a person otherwise inclined to crime. Retribution is the intentional infliction of pain and suffering on a criminal to the extent he deserves it because he has willingly committed a crime. General deterrence is the pressure that the example of one criminal's pain and suffering exerts on potential criminals to forgo their contemplated crimes. Specific deterrence is the pressure that unpleasant memories of incarceration exert on a released convict, which cause him to obey the law. Rehabilitation is the acquisition of skills or values which convert a criminal into a law-abiding citizen.

"Each of these concepts represents a complex series of moral assertions, beliefs about human nature, and aspirations for the criminal justice system."6 And for centuries, seemingly, these "great theories of

4. Nightline covered this event from inside Lorton Prison, where Ted Koppel walked among a group of inmates involved in drug rehabilitation. Nightline: Reaction to Bush's Antidrug Speech (ABC television broadcast, Sept. 5, 1989).

5. "Certainly the word 'crisis' is a strange one to use when describing problems that appear to be chronic." D.C. Bar Coordinating Committee on Prisons and Prisoners, A Primer on OUR Prisons 4 (1989) (on file with the Slanford Law Review).

6. Peter W. Low, John Calvin Jeffries, Jr. \& Richard J. Bonnie, Criminal Law 1 (2d ed. 1986). Another of these concepts, "punishment" as a reassertion of social solidarity by ritual denunciation, receives less attention in the literature and in this discussion. 
punishment" have stood "in open and flagrant contradiction."7 Philosophers and criminologists-often as a basis for penal reform-advocated a single definition, purpose, or justification for punishment, to the exclusion of all others. If rehabilitation was espoused, retribution was "damned as a vestige of man's instinctual past, while deterrence [was] excluded as ineffective, or rationalistic." 8 Retribution advocates often dismissed deterrence as a myth, and rehabilitation as impossible or immoral, while rehabilitationists see retribution as vengeful, sadistic, and pointless. But the assumption that punishment can and must be conceived only in terms of these clashing categories continues to pervade the vast and growing literature. ${ }^{9}$

In the last fifty years, with the appearance of many fine summaries and samplers of the traditional literature, ${ }^{10}$ most experts have embraced an inclusive view of punishment as common sense: "[A]ll, (or at least most) of the theories deserve some consideration." "l Recognizing that each perspective has its strengths and weaknesses, and that no one can supplant the others, reformers now seek to blend traditional purposes into a workable system of punishment. ${ }^{12}$ Like ingredients in a recipe, each goal or justification will be represented in its appropriate proportion.

The authors of the Model Penal Code wished away the problem of

7. Philip Bean, Punishment: A Philosophical and Criminological Inquiry 11 (1981).

8. Jerome Hall, General Principles of Criminal Law 303 (2d ed. 1960).

9. Even as they increase it, authors commonly acknowledge the vastness of the literature. Id. at 303 (referring to "the voluminous writing on punishment"); SANFORD H. KADISH \& Monrad G. Paulsen, Criminal Law and Its Processes 214 (3d ed. 1975) (noting the "vast and growing contemporary literature on the subject of punishment"); FrankLIN E. ZIMRING \& Richard S. Frase, The Criminal Justice System 754 (1980) (noting that the "[d]ebate on the purpose of criminal punishment constitutes one of the most voluminous literatures in philosophy and law"); Federal Sentencing Guideline Manual 3 (1988) (stating that the "relevant literature is vast, the arguments deep, and each point of view has much to be said in its favor").

10. Among the many fine anthologies, most useful were: Morris R. Cohen \& Felix S. Cohen, Readings on Jurisprudence and Legal Philosophy 280-366 (1951); Jerome Hall, Robert Force \& B.J. George, Jr., Criminal Law (4th ed. 1983); Sanford H. Kadish, Stephen J. Schulhofer \& Monrad G. Paulsen, Criminal Law and Its Processes 181-248 (4th ed. 1983); John Kaplan \& Jerome H. Skolnick, Criminal Justice 47-87 (3d ed. 1987); Lloyd L. Weinreb, Criminal Law (4th ed. 1986); F. Zimring \& R. Frase, supra note 9. Of many fine essays summarizing the various conceptions of punishment, one of the first integrative approaches is Morris R. Cohen, Moral Aspects of the Criminal Law, 49 YALE L.J. 987 (1940). Other essays most used here were P. BEAN, supra note 7; J. HaLL, supra note 8; WAyne R. LAFAve \& Austin W. Scott, Jr., Criminal Law 22-29 (2d ed. 1986); P. Low, J. Jefrries \& R. Bonnie, supra note 6, at 1-28; Herbert L. Packer, The Limits of the Criminal Sanction 9-145 (1968); Andrew Von Hirsch, Doing Justice: The Choice of Punishments (1976); Martin R. Gardner, The Renaissance of Retribution-An Examination of Doing Justice, 1976 Wis. L. REv. 781; Henry M. Hart, Jr., The dims of the Criminal Law, 23 Law \& Contemp. Probs. 401 (1958).

11. W. LAFave \& A. Scott, supra note 10, at 27 (citation omitted). Each concept of punishment is "complex and ... none may be thought of as wholly excluding the others. .. . The problem, accordingly, is one of the priority and relationship of purposes as well as of their legitimacy ...." Hart, supra note 10, at 401; see also J. HaLl, supra note 8, at 308; W. LAFAve \& A. ScotT, supra note 10, at 27.

12. F.J.O. Coddington, Problems of Punishment, 46 Proc. Aristotelian Soc'y (n.s.) 155, $178(1946)$. 
balancing the justifications and purposes of punishment, ${ }^{13}$ trusting that somehow legislatures, courts, and correctional departments would set the priorities. Similarly, when Congress established the United States Sentencing Commission to promulgate uniform sentences for federal crimes, it rejected rehabilitation, but did not specify how the remaining philosophies were to be blended. ${ }^{14}$

Those who do priorities among the various justifications or purposes of punishment, almost without exception address the problem conceptually, as a matter of logic or philosophy. Without discussion, they assume that an appropriate blend of retribution, deterrence, incapacitation, and rehabilitation ultimately translates into a number, or number range, such as "10 years in prison" or "5-to-15 years in prison." A legislature or court need merely increase or decrease the length of the "sentence" to increase or decrease retribution, rehabilitation, deterrence, or incapacitation. ${ }^{15}$ Often this abstraction is obscured: the number becomes the punishment rather than a symbol of its duration ${ }^{16}$ which is only one dimension of a prisoner's actual pain and suffering.

Punishment, however, is not merely the quantity of time in prison. The reality of each criminal's punishment consists in the experience of that punishment. What actually happens to prisoners-their daily pain and suffering inside prison-is the only true measure of whether the traditional concepts have meaning, the traditional goals are fulfilled, the traditional definitions apply. Only through the prisoners' experience can we test the categories, clarify these concepts, and set priorities. ${ }^{17}$

13. Model Penal Code $\$ 1.02$ comment (1954).

14. See notes 102-103 infra and accompanying text.

15. Originally colonial Americans "fined or whipped criminals or put them in stocks or, if the crime was serious enough, hung them; they did not conceive of imprisoning them for specific periods of time." David J. Rothman, Discovery of the Asylum: Social Order and Disorder in the NEw REPublic xiii (1971). But "[t]he philosophy of the Enlightenment aided the belief that at long last society could make a punishment fit the crime by rationally assigning sentences of various lengths with the handy metric of time." GRESham M. SYKES, ThE Society of Captives: A Study of a Maximum Security Prison xi (i958) (emphasis added).

16. "[N]umbers have taken the place of the concrete facts of punishment." GraEmE Newman, Just and Painful: A Case for the Corporal Purishment of Criminals 35 (1983). Perhaps this tendency to convert the duration of imprisonment into the measure of punishment-without attention to what happens to the prisoner inside prison-comes from the historical origins of prison. Between 1790 and 1830 in the United States, the penitentiary became the basic mechanism of punishment. "Incarceration seemed more humane than hanging and less brutal than whipping. Prisons matched punishment to crime precisely: the more heinous the offense, the longer the sentence.... The fact of imprisonment, not its internal routine, was of chief importance." D. Rothman, supra note 15, at 62 (emphasis added). Innovators hoped penitentiaries would rehabilitate inmates and, by their success, set an example of right conduct for the larger society. But no one paid much attention to what happened inside prison. By 1850 , the penitentiary was failing to accomplish its original goals: retribution and incapacitation replaced rehabilitation and general deterrence as purposes for the penitentiary. See id. at xiv, xix, 1-108, 237-57. Yet, the lenglh of sentence-a metric of timeremained the primary measurement of punishment.

17. "I wish to illustrate the truth that the procedure from principles to facts and from facts to principles, without assuming either to be absolute or unquestionable, does not at all 
Many convicts have written of their ordeals in prison, mostly anecdotally. ${ }^{18}$ None has sought new meaning from their pain and suffering by applying traditional concepts, theories, purposes, and justifications of punishment to daily life inside prison. Sociologists, and of course criminologists, have spent time inside prisons, analyzing the prisoners' experiences, but from a structural, institutional, organizational perspective. ${ }^{19}$ Philosophers and criminal law professors, however, these past fifty years have not sought a solution to the problem of setting priorities among the concepts of punishment by bringing those concepts to bear on prisoners' experience of punishment. ${ }^{20}$

But the prisoners' actual experiences, and those experiences as imagined by others, or (mis)remembered by themselves, are not only the reality of punishment but also the basis for its validity. Ultimately,

lead to complete moral nihilism, but rather clarifies the process of building a systematic view of what the law should do." Cohen, supra note 10 , at 987.

18. For an annotated bibliography of published works by American prisoners and exprisoners from 1798 to 1988, see H. Bruce Franklin, Prison LIterature in AMERICA 291 (1989).

19. In The Sociely of Captives: A Siudy of a Maximum Security Prison, deservedly a modern classic, Gresham Sykes observes that "[t]he social system of the [prison] lies in a philosophical environment as well as a physical one and the nature of the prison's social system only becomes clear when we understand the rationale on which it is based." G. SykEs, supra note 15, at 9. Sykes then succinctly spells out the principal objectives and justifications of imprisonment, and points to conflicting pressures among those objectives. Id. at 9-12. But with his "main attention" directed to the "complex set of interrelated patterns of social relationships," he gives the "philosophical setting" which lurks in the background only brief, but enlightened, attention. Id. at xix, 12.

Essays by sociologist Donald R. Cressey also hint at the perspective adopted in this study. In his Achievement of an Unstated Organizational Goal: An Observation on Prisons, 1 PAC. Soc. REV. 43 (1958), Cressey observes, "It is customary for both sociologists and correctional workers to adopt the viewpoint of society, rather than of the prisoner, when discussing the goals of prisons...." Id. at 43. After noting the "integrative function" which prisons serve for societyi.e., incapacitating, punishing, and reforming criminals-Cressey observes that " $[t]$ he goals of prison also can be considered from the viewpoint of the criminal." Id. Cressey's purpose in this brief essay is to suggest how two prisons-both very different from Lorton Centralprotect prisoners either "from the stares of organized tourists," id. at 45 , or "from ridicule ... by staff members," $i d$. at 48 . Elsewhere Cressey observes that "[ $t]$ he prison, as such, does not do anything at all. It just sits there-upstate, across the bay, or on the edge of town-ugly, menacing. What counts is the subtle specifics of each prisoner's participation in prison life." Donald R. Cressey, Adult Felons in Prison, in Prisoners in America 117, 118 (L. Ohlin ed. 1973). Cressey notes how conflicting categories impose "organizational strain" on the prison administration: "In the good old days, punishment was assumed to do everything, but now our directives to prison administrators are inherently contradictory," id. at 128-29, resulting in a "deluge of doubletalk that pours out of prison public relations offices," $i d$. at 125 .

Sociologist Erving Goffman notes that " $[\mathrm{t}\}$ he avowed goals of total institutions are not great in number." Erving Goffman, AsyLums 83 (1961). For prisons, Goffman lists the standard "incapacitation, retribution, deterrence and reformation," id. (quoting Cressey, Achievement of an Unstated Organizational Goal, supra), and then observes: "[E]ach of these official goals or charters seems admirably suited to provide a key to meaning - a language of explanation that the staff, and sometimes the inmates, can bring to every crevice of action in the institution." Id. Goffman leaves this very suggestive reference unexplored.

20. For example, P. BEAN, supra note 7, and Paul H. Robinson's theoretically interesting Hybrid Principles for the Distribution of Criminal Sanctions, 82 Nw. U.L. REv. 19 (1987), are almost devoid of reference to experience, even though the former is one of the most sustained attempts to explore the interactions of various concepts. 
only through experience can the concepts be tested. And only by the concepts can the experience be justified. This study, then, attempts to bridge the gap between traditional penal philosophy and the actual experience of punishment.

\section{B. Limits of the Study}

Since 1986, at the suggestion of Professor Philip B. Heymann ${ }^{21}$ and with the full cooperation of Walter Ridley, Chief of Operations of the Washington, D.C. Department of Corrections, ${ }^{22}$ the author and John Allen, inmate \# 129375, have spent hundreds of hours together inside Lorton Central Prison, documenting the daily lives of Johnny's friends and acquaintances. We have probed deeply, exploring with the prisoners their childhood, their street hustles, their political views, their moral codes, their philosophy of life, and, of course, their experience inside the "joint" (the prison).

We did not calculate exactly how many inmates took each position, nor did we even attempt a truly representative sample of Lorton Central prisoners. Johnny, in his mid-forties, had friends who were generally older and more thoughtful than average. Moreover, Lorton Central is hardly a typical prison: In a 68 -acre complex about 25 miles south of Washington, D.C., in lush Virginia farmland, strips of dormitories house approximately 1300 long-term felons who have committed serious street crimes in Washington. True to the concept of "home rule" for the nation's capital, the prison administration is mostly black; the prison population is more than 99 percent black. This is not, then, a statistical analysis. It is a field study-a philosophical field study-of one prison only. ${ }^{23}$ And although this study hardly qualifies as an account of an average prison experience across the United States, the national focus on Washington, D.C.'s reaction to its crime-infested streets

21. Professor Heymann, former Chief of the Criminal Division of the Justice Department, urged this author to undertake a study inside Lorton Central where John Allen, a former client whom Heymann had successfully defended on a robbery prosecution, was confined. As originally envisioned, John and his fellow inmates would reveal if longer sentences meted out these past fifteen years had any deterrent effect and whether the values of the younger generation were different from those of the old-timers when they were young.

22. Walter Ridley displayed courage in permitting this study, as did Lorton Central's warden, David Roach, in so fully cooperating. Gresham Sykes observed in his study of a maximum security prison that "[c]areers, jobs, and reputations depend on the efficient functioning of the prison and what is a familiar administrative problem for the prison bureaucracy can become a scandal of mismanagement if it is made public." G. Sykes, supra note 15, at xix. This is especially true in the intense political atmosphere of Washington, D.C.

23. Lorton Central and Maximum are technically two separate prisons sharing a common wall, with separate administrators and different conditions. Maximum is cellular with carefully controlled movement. Central is dormitory style. Inmates are regularly transferred from one to the other. To those at Central, Maximum is "behind the wall," while to those who expect to return from Maximum, Central is the "compound" or the "hill." From the inmates' perspectives, the prisons are two facets of one Lorton prison complex. In fact, Lorton comprises seven prisons-Central, Maximum, Minimum, Occoquan 1, Occoquan 2, Youth Center 1, and Youth Center 2. Inmates refer to Central as "Big Lorton." Along with inmates and staff, we use "Lorton" and "Central" interchangeably. 
makes it at least symbolically significant, and the interviews ensure that this composite account is revealing, because its source is real.

How do we know we have not been conned? Why should prisoners be truthful? One check, of course, has been personal observation. Hundreds of hours inside a prison with permission to go anywhere and to talk to anyone privately at length, is itself a gross check on others' distorted descriptions of reality. A more important check was Johnny himself. A bank robber who has been in and out of prison, Johnny Allen's earlier life story-Assault with a Deadly Weapon: The Autobiography of a Street Criminal ${ }^{24}$-had been well received as an accurate and thoughtful self-portrait of inner city street life. Long confined to a wheelchair, permanently paralyzed from the waist down by a police officer's bullet having shattered his spine, Johnny had once again returned to Lorton Central, his last armed robbery-of a drug dealer-committed from the wheelchair. But now, separated once again from his children and grandchildren, a drug free, mature and reflective old-timer, Johnny, for the first time in his life had promised himself that this was it: He would never return to prison. His goal was to help kids-his own and others-avoid his mistakes. So John Allen fervently embraced the goals of the study, typically beginning each interview by declaring that "truth is our thing: You don't have to answer anything you don't want, but if you do answer, make it the truth, or at least the truth as you see it. Otherwise you mess up our whole thing." From the inmates' perspective the setting was private and comfortable, the interviewers were Johnny-a well-respected convict, often a friend-and his white lawyer (the author) for whom he vouched. We made it clear that we cared about their opinions on the quality of their lives, their feelings about themselves, their race, their families, and others in the joint. Many conversations became intimate: At the end of an initial or follow-up session which often lasted several hours, inmates commonly expressed surprise that they had revealed so much. On those rare occasions when someone said something that rang false to Johnny, he would question it. The administration gave Johnny permission to keep a tape recorder. Thus, many interviews were conducted solely between Johnny and other prisoners. Comparing the prisoners' accounts has given us an additional internal check. Positions articulated by a vast majority we treated as consensus and present here as fact.

Corrections officers, as participant observers, also provided important verification. The D.C. Department of Corrections (D.C.D.C.) encouraged all willing officers, including David Roach, Lorton Central's Administrator (warden), to cooperate fully with this project. Having spent their days, in some cases careers, inside Lorton Central, officers could dispute or corroborate inmate versions. Despite its faults, then,

24. John Allen, Assault Wrth a Deadly Weapon: The Autoblography of a Street Criminal. (D. Kelly \& P. Heymann eds. 1977). 
this account of life inside Washington, D.G.'s principal prison allows us to compare traditional theories of punishment with a collective experience of punishment.

\section{InSide LoRTON Central}

Retribution, deterrence (general and specific), rehabilitation, and incapacitation represent overlapping and antithetical perspectives on why, when, and to what degree criminals should undergo pain and suffering through punishment. In order to evaluate these various definitions, justifications, and goals of punishment, therefore, we need to know whether and how prisoners do in fact suffer inside Lorton Central.

Of course everyone's "bit"- time spent in prison-is different. One individual feels a loss of freedom more or less than another. A forced separation from home, and the streets, and entrance into a new prison environment can be more or less painful. Losing family ties may cause a criminal to suffer differently at different stages of life. And in the course of each day, moment to moment, a prisoner's experience of prison changes.

\section{A. Lorton as "Hell Hole"}

"A hell hole" inmate Thomas "Butch" Sheppard called Lorton Central. "I hate it with a passion," inmate Dean Martin declared. "The garbage you eat every day; police in your face all the time. This ain't no peaches and cream." Johnny Allen painted a portrait of maximum suffering inside the joint to frighten a 15-year-old who was hustling in small ways, but who had, as yet, no real criminal record:

"First of all, all first timers do hard time, and whatever dues you pay in the joint stick with you from then on out. First impressions count, so if you were carried real rough and you have the misfortune of coming back, then the same things that happen to you the first time will happen throughout your time in jail no matter what you do. If you don't know anyone that's pretty much known around the institution, then you are in big trouble. You can't trust nobody. When you're new, then everybody gets on you. Convicts, first and foremost, and the officers also.

"The officers will not give you any respect. None, when they see you are weak. They will try to make snitches out of you, become your friend, give you cigarettes so you can tell on the inmates that's in your dorm.

"You can't go anywhere but here, Lorton. You can't run down to Micky D's and get a couple of cheeseburgers. You can't go to the go-go clubs anymore. You can't drive that ride, be with the little girls that you always like to have underneath you. You got to be in your dormitory for the count. And you must submit to shakedowns at random. That means that any officer can call you at any time and not only pat you 
down but strip-search you. When an officer comes into the dormitory he or she can go over every inch of your personal property, your mail. You have no rights. None. You must always abide by the institution rules.

"Now there are institution administrative rules that you must go by, and there are also institution convict rules that you must go by. Sometimes the two clash. And if you get busted going with the convict rules, then the administration make you pay by sending you to the hole [detention cell] or the wall [maximum security cell block], or even transferring you. If you go with the administration rules and stay on the administration side, then the convicts make you pay: Late at night somebody will come to your bunk while you sleep, hit you in your head or 'shank' [stab] you. If they don't move against you violently, then the verbal abuse is hell. And when you come back from your job or school, all your stuff, your personal letters, clothes, TV, all of your property including your bed, is out on the walk. So you see, any way you do it you lose.

"You have to choose your friends very carefully, and nine people out of ten who you might think is your friend is not. He wants something from you. He will either want to get your butt or to use you in some other way, to wash his clothes, to do petty thefts for him. If you get visits, then he'll want to use you and your people by having them bring contraband into the institution for him. Or if you get money, he'll want it. He'll befriend you to use you.

"Guys will fuck you. They will throw a blanket over your head, grease your ass and fuck you. And have no remorse about it. Once you are fucked, everybody knows about it, and then you can't turn nobody down. Anybody think they can talk you out of your butt will talk you out of your butt, and before long not only are they fucking you but you're sucking dicks and washing people's drawers and socks just like a slave. And this happens to the majority of first-timers that come in. They may not admit it. Who want to own up to being fucked or having to wash dirty drawers for one whole side of the dormitory?

"Every convict in the institution is a loser, but you got one drawback. You are a weak loser. Nine out of ten new boys that come in are junkies in less than two years. So when you go on a visit and your mother come down or your girlfriend and you take that twenty dollars or thirty dollars or whatever they can afford to give you-maybe you can get a hundred dollars, one hundred fifty dollars-grease your butt up before you went into the visiting hall and slide that money up your rectum. And when you get out of the visiting hall, get through shakedown, and back to the dorm, all the money that's not directly taken from you, you give to the dope man. Because we all know that dope in any form is escapism and you're gonna need escapism every chance you can get. You want to forget what your day is going to be like tomorrow. 
"You can't get sick here. Because if you get sick, none of the medical people would even care. If you have a chest ache or a stomach pain or any kind of ache, you get two Tylenols. If you are not bleeding, you get two Tylenols. If you are bad enough after you've laid around for a few hours, then they might send you uptown. So you can't afford never to step on anybody's toes. You can't ever put yourself in a position where you get hurt. Because if you get stabbed and don't die instantly, there is always the possibility that you die right here in the infirmary.

"There's going to come a time that you want to die. And many new boys do die. They hang themselves. They cut their wrists. Most of them make bad attempts at it, or most of them do it for sympathy. But when that day come that you so pressed and depressed that you want to die, or you want someone to feel sorry for you and you come back to the dorm and you tear your sheets and you make a rope and you throw it over a pipe and tie it down and make a noose and you climb up on a trash can and put the noose around your neck, everybody in the dormitory is going to be cheering you on. 'Go ahead nigger do it. Do it nigger do it. Jump nigger, hang yourself, do it!' And if you got heart enough to follow through and jump off that can and don't break your neck, but strangle, as you strangling for that half minute when that sheet tightening around your neck, all you can hear is laughter. Because nobody gives a damn. Nobody."

Is an inmate's pain and suffering at the hands of other prisoners, and not by command of the administration, properly part of punishment? From Hobbes to H.L.A. Hart, many standard definitions require that punishment be inflicted only by an authorized official, pursuant to law, ${ }^{25}$ whereas in Johnny's account, much inmate suffering is unofficial. But to insist that "punishment" includes only authorized pain and suffering seems a little like disavowing the snake bites after throwing someone into a snake pit. Standard definitions of punishment must be

25. Hobbes defined punishment as "an Evill inflicted by publique Authority on him that hath done, or omitted that which is Judged by the same Authority to be a Transgression of the Law; to the end that the will of men may thereby the better be disposed to obedience." Thomas Hobbes, Leviathan 353 (C.B. Macpherson ed. 1968) (1651).

H.L.A. Hart defines "the standard or central case of "punishment" " by listing five elements:

(i) It must involve pain or other consequences normally considered unpleasant.

(ii) It must be for an offence against legal rules

(iii) It must be of an actual or supposed offender for his offence.

(iv) It must be intentionally administered by human beings other than the offender.

(v) It must be imposed and administered by an authorily constituted by a legal system against which the offence is committed.

H.L.A. Hart, Punishment and Responsibility 4-5 (1968) (emphasis added). Hart broadens his definition of punishment by introducing "sub-standard cases" of punishment, including punishment not administered by officials. Id. at 5 .

Jerome Hall's definition also emphasizes its "official" aspect, and states in part: "First, punishment is a privation (evil, pain, disvalue). Second, it is coercive. Third, it is inflicted in the name of the State; it is 'authorized.' Fourth, punishment presupposes rules, their violation, and a more or less formal determination of that, expressed in a judgement." J. HaL.L, supra note 8 , at 310 . 
expanded to include characteristic daily suffering in prison, from whatever source.

\section{B. Lorton as "Sweet Joint"}

Expressing a somewhat different view, Johnny consoled a close friend's younger brother, about to start a thirty year sentence, terrified and considering suicide:

"It's really not a bad place. Not at all. In fact this is one of the best places in the country to do your time. If you don't bother nobody, nobody will bother you. If you carry yourself in a manly manner then you'll be treated in a manly way. As for your time, and how to get started on it, that's up to you. You have a few options. You can try to get into a regular squad which make you about twenty, twenty-five dollars a month. Or you can try to get into industry which makes about a hundred, a hundred fifty dollars a month. You can go to school and if you don't want to, you don't have to do none of that. You don't have to work if you don't want to. You can spend your time keeping yourself in shape, you can spend your time reading and working on whatever you want to work on to take up your time.

"Just recently they stopped letting you send home for TVs but as you see I've got a color TV right here that belongs to me. There's also a color TV in every dormitory. You can also see that I've got a radio with a tape player on it so I can play my music any time I want to as loud as I want to or as soft as I want to. I can put my earphone in if I want to and I don't have to if I don't want to. You can do the same thing. ... [Y] ou can have just about any kind of clothes you want, any kind of tennis shoes you want, all different kinds of hats. The joint is pretty loose. Now if you really want your TV then I'll keep my ears open for someone who's got one for sale. Because you can buy a TV of your own and whoever sell it to you can forge the right papers so you can have your paper work done like you had your TV all the time. You can lay back down in your bunk like I do with your remote control in your hand, turning from channel to channel. Or play the radio. If not, then I can put a couple of Marvin Gaye tapes in there, or Smokey Robinson.

"Relax. You can get a job if you want to. If you don't want to you don't have to. You can go to school if you want to; if you don't, you don't have to. The day is yours and the nights are yours, from anytime after the morning count-the count is at seven o'clock, and it usually clears around eight. They count again at eleven, then they count again at three-thirty. Then they don't count no more until ten-thirty at night. From eight a.m. 'till ten-thirty at night, you can do what you please. You can go where you want, anywhere in the camp you want. Any dormitory, any yard, the track, the gymnasium. Anywhere you want to go 
you can go, anywhere, except out the gate. The only thing that you have to do is to be on your bunk at count time.

"Now most of the dormitories in Lorton are like small families. As you walk around, you'll see some of your friends. If they good enough friends of yours, you can get in the dorm with them, the same guys you hung out with on the street. An officer may come into the dormitory and take a look around, but basically he only stay two or three minutes in there. Don't no dormitory hold no officers. Don't no officers stay in no dormitory all day. For no reason. The officers' posts are out on the walk. Sometimes an officer might see a lot of traffic coming in and out of a dormitory and he might check it out and see what he can catch, and that's usually some officer that's gung-ho and trying to make sergeant. But most of the time there's no officers in the dormitories. During the night, they count about every hour-until four-thirty in the morning. They stop counting and they don't count no more until seven. So the dormitory's pretty much our own.

"There are certain things that you can do to make yourself more comfortable or to make your bit easier. The dining hall has a long line to get in, and once you get in it's crowded and it's hot, and for real, the food ain't that good. But for ten dollars a month, you can contract a dude to fix you a meal every day. If you want breakfast every morning, then someone will fix you breakfast every morning. Not only does he prepare this better food, but it's his job as part of the contract to get the food to you so you can lay back in bed and the guy bring you breakfast in bed every morning. For twenty dollars, or twenty-five dollars a month, you can get two meals a day-a better quality of food, better prepared, and brought to you in the dormitory. Twice a day. Every day. Including weekends.

"A lot of guys wash their own clothes, but you don't have to. Once a week a guy comes around and pick up your laundry, and return it to you the same day. He be washing your whites-underclothes, socks, sweat clothes. But your shirts and jeans that you wear on visits be pressed crisp and clean. That costs about ten dollars a month.

"Now if you like to get high, all the same things that's available to you on the street is available here at Lorton. If you like to smoke marijuana, there's plenty of it here. And for five dollars, you can buy a couple of joints. If you're on heroin, you can buy heroin. Cocaine, PCP and a number of other drugs, pharmaceutical drugs, drug store drugs. Anything that you want is here.

"All the TVs in every dormitory is hooked up to a VCR and every weekend they show two movies. They have the latest movies. In fact we just seen Raw with Eddie Murphy, Fatal Attraction, Moving, with Richard Pryor, Steel [Full] Metal Jacket. As soon as they come on video, we have them. And they show two of them on Sundays and two on Satur- 
days. Whenever there's a big fight like a Michael Tyson fight, then a week later we see this on video.

"When you watching TV, you can get to the canteen truck which has got all kinds of goodies on there. Cookies, potato chips, popcorn, sardines, tuna, candy, mayonnaise, cigarettes, cigars, pipes, almost everything that's in the store is on the canteen truck. And if for some reason or another you miss canteen, or you in between canteen books and you got a few dollars, then somebody always running a store that sell pretty much the same things that a guy want to snack on while he looking at the video late night. Friday night videos come on and you want some pastries, cold sodas, and you got a couple of dollars you can buy these things. You can stay up late as you want. The TV can stay on all night, the radio can stay on all night, all day.

"Basically, you can do a comfortable bit, because all the things that you need, and most of the things that you want, are right here. Now I understand that you've never done any hard time, but Lorton is not a hard place to do time in. In Lorton you can do easy time, comfortable time.

"Now if you want to get your dick sucked, you can do that. They got dick-sucking faggots in here that'll suck your dick for two dollars. If men ain't your thing, after you're here for awhile, you'll learn the other things to do. Those little girls will come and see you, and there's ways for you to be with her for ten to fifteen minutes alone. You'll learn all these things within sixty to ninety days of being here. You'll learn how to get over in the visiting hall as far as being with your woman and having sex, and a number of other things.

"Lorton is the best place to do time for anybody. Not that far from town, twenty-something miles. Takes about a half hour to get here from town. If your woman's car break down, or your family car break down, there's two busses a day that come here, every day. You get thirteen hours a month for visits. Very seldom are the hours counted. After you use your thirteen hours up, if you go to your classification and parole officer, then he or she will let you get your visits.

"So be yourself, relax and carry yourself in a manly manner, and everything will work itself out. A month from now you'll be wondering why you ever thought about killing yourself, or why you had so much fear of Lorton. A month from now you'll be running around here like everyone else, having a good time."

\section{Haven or Hell?}

Which kid was told it straight? What is the real experience of Lorton? Obviously it depends. Some guys breeze through it; others live in agony. Even Douglas Wright who called Lorton a "playground" qualified it: "[A] playground to all those youngsters who don't know what's happening." 
Almost uniformly the older inmates condemn Lorton Central as a "deathtrap." "You can get killed because you have no protection," said Danny Bethel, one of many prisoners who has been stabbed. "You can't go to a dark room; you can't take a bucket and wash your clothes without realizing it's possible you might not come out. It's no such place as that you're guaranteed to see tomorrow. You go to bed with a nightmare, and the only peace that you ever get is not waking up at all."

"For even those like myself who are, I'm not proud to say, accomplished jailers, it's rough," admitted Johnny, trying to be objective. "I know never to put my guard down. Never to trust anybody. Anything can happen. Nobody play fair. Jail is death. At one time a guy could come in and know that when his time was up he was going out. Now a guy come in here and he's not sure if he's going to be killed before his time is up."

On the 68-acre compound, there are a thousand corners and hidden places, and very few guards, ordinarily stationed at widely separated quarter posts. Everyone can obtain a "shank"-a knife of some sortranging from a sharpened chicken bone held between thumb and forefinger used to stab an eye or Adam's apple, to an ax or sword. A common shank looks like a Bowie knife, sharpened finely with a handle wrapped in leather. Typically, for ten dollars prisoners can replace confiscated shanks in less than a day. They do not keep their weapons on their persons or in their lockers, but in easily accessible hiding places. A prisoner who is expecting to attack or be attacked arms himself and is "strapped down." A sweatshirt on a hot day often covers the weapon and also magazines, which, like a bullet proof vest, protect an inmate's middle from attack. Guns are rare, although some have been confiscated recently. Officers patrolling the compound may not legally carry weapons, only walkie-talkies. The prisoners are convinced that when a fight breaks out, officers cannot and will not protect them. Few inmates blame them.

Drugs, which permeate the prison, make the prisoners feel continually vulnerable. "If a dude smoke boat [PCP-soaked marijuana], there's no way you can pinpoint anything. One moment a guy be calm; the next moment he be tearing your head off and crying like a baby," said Danny Bethel. "So you can be killed for anything and it's scary, it's really scary."

Prisoners constantly confront life-threatening situations. If you let someone cut in line in front of you, others will take greater advantage. But if you confront him, you face possible lethal retaliation. Phone lines, canteen lines, chow lines, the gym-all are dangerous spots. A new prison ethos prevails among the younger generation: Smaller slights are taken as disrespect. Today's kids no longer settle "beefs" by fists; no longer is a fair fight one-on-one with equal weapons. Routinely now, they wear masks and attack in groups. 
Avoiding deadly confrontations is a never-ending challenge. "I would consider Lorton a 'hell hole' being that life is always on the line. At all times really. I never get to relax," complained inmate Andre Mitchell. "It's been known as far as people getting hurt that they never the ones that did anything. The innocent bystanders or people mistaken. I always stay on my toes. I'm a little jumpy. People say I'm scared, but it's not that. I don't want to be the victim."

Inmates' fears are realistic. Except for the "hole"-one small detention wing with individual detention cells-Lorton Central is composed of dormitories each housing dozens of inmates. A prisoner cannot remove himself to a safe place without invoking administrative procedure. He cannot simply lock himself in his cell. A sleeping inmate is vulnerable to lethal attack not only from his dormmates, but also from outside intruders: The dormitory doors do not lock. Inmates routinely complain that they have no moments of peace. They must never sleep deeply, never for an instant let the soap cover both eyes while showering.

Historically, early forms of punishment centered on physical torture. French philosopher Michel Foucault observed, however, that modern punishment, especially imprisonment, is focused on "the soul. The expiation that once rained down upon the body must be replaced by a punishment that acts in depth on the heart, the thoughts, the will, the inclinations." 26 Most old-timers prefer the Lorton of twenty years ago-even with corporal punishment meted out by hostile guards and rules more strictly enforced-to the mental strains of today's prison.

"If it's not as hard physically," said Johnny, "it's harder mentally." "Dealing with these people's minds, getting around them. It's not a matter of strength, it's a matter of matching wits," 6-foot, 7-inch, 300pound inmate Scott Walker complained. "You're not breaking rocks. Breaking minds is what you are doing, and that's worse than beating on a rock."

\section{The Experience of Lorton Central Justified}

\section{A. Retribution}

He who kills a man shall be put to death. ... When a man causes a disfigurement in his neighbor, as he has done it shall be done to him, fracture for fracture, eye for eye, tooth for tooth; as he has disfigured a man, he shall be disfigured.

Leviticus 24:17-20

26. Michel Foucault, Discipline and Punish 16 (A. Sheridan trans. 1977). "Prisons today are less overtly and intentionally painful than their predecessors," wrote Robert Johnson in Hard Time, a useful primer that cites and samples much recent criminological literature. "Neither physical pain nor mental or emotional abuse are planned features of modern imprisonment. The pains experienced in contemporary prisons, for all intents and purposes, originate in psychological stresses." ROBERT Johnson, HARD TIME 55 (1987). 
Retribution is perhaps the oldest measure of punishment: like for like-pain and suffering for pain and suffering. The Bible commands: "[A]s he has done, it shall be done to him." 27 Scorned by a shrinking majority of scholars, retribution continues to be embraced by a large majority of citizens. ${ }^{28}$ Retributivists have recognized that strict repayment is not always possible: If a criminal takes out the only eye of a one-eyed man, surely to take out only one of his two good eyes is not full retribution, ${ }^{29}$ whereas to take them both out is not exact recompense. Retribution has advanced beyond exact retaliation to become what it is today-proportional punishment. Punishment should be proportional to the gravity of the crime. ${ }^{30}$

Retributivists differ as to the appropriate length and intensity of punishment attaching to particular crimes. Some may see violent crime as incomparably more deserving of punishment than non-violent crime; others may feel that crimes which affect the public generally, such as illegally dumping toxic wastes, or cheating the elderly out of their life savings, or a public official's bribe-receiving deserve the greater punishment. To a degree these differences of opinion are subjective and arbitrary, but only to a degree. Since Aristotle, malum in se, a thing bad in itself, has been distinguished from malum prohibitum, a thing bad only because defined as illegal, or as inmate Alvin Hines called it, "a manmade crime." Murder, rape, robbery: These are serious crimes, bad in themselves. But is selling drugs? In 1990, a small but respectable chorus including judges and legislators calls for the legalization of narcotics. Yet, during this era of prohibition, many prisoners are serving very long and painful sentences for engaging in truly consensual transactions that perhaps should not be illegal, while others for whom killing is a business decision, who maintain deadly workplaces or poison our water are sentenced to community service or not punished at all. Is this

27. Leviticus 24:19 (Revised Standard). The ancient Code of Hammurabi $\$ 196$ also declared, "If a man has put out the eye of a free man, they shall put out his eye." THE BABYLoNIAN LAws 77 (G.R. Driver \& J. Miles ed. 1955).

28. Cf. Andrew H. Malcolm, Tainted Verdicts Resurrect Specter of Executing the Innocent, N.Y. Times, May 3, 1989, at A18, col. 1 (quoting a professor of jurisprudence as tracing strong public support of capital punishment to retributivist sentiments).

29. See M. COHEN \& F. Cohen, supra note 10, at 325 (quoting their own translation of G.W.F. Hegel, Philosophy of Right) ("To adhere obstinately to the equalization of punishment and crime in every case would reduce retribution to an absurdity."). A similar translation exists in G.W.F. Hegel, Philosophy of Right 72 (T.M. Knox trans. 1952). Hegel reverses the example used in the text: "It would be necessary ... to demand an eye for an eye and a tooth for a tooth, although the criminal, as we can easily fancy, might have only one eye or be toothless." M. COHEN \& F. CoHEN, supra note 10, at 325.

" $[T]$ here are very many crimes, that will in no shape admit of these penalties, without manifest absurdity and wickedness. Theft cannot be punished by theft, defamation by defamation, forgery by forgery, adultery by adultery ..." 4 W. BLACKSTONE, CoMMENTARIES *I3, ciled in H.L.A. HART, supra note 25, at 161.

30. Proportionality is not an entirely new concept. The Bible recognized it: "[T]hen if the guilty man deserves to be beaten, the judge shall cause him to lie down and be beaten in his presence with a number of stripes in proportion to his offense." Deuteronomy 25:2 (Revised Standard) (emphasis added). 
proportional? Proportional to what? To the criminal's culpable mental state, to his conduct, to the ultimate harm caused?

Traditionally, retributivists seek punishment formally administered by public officials on unwilling criminals in proportion to the seriousness of the crimes they have committed. For many commentators and officers, the length of the sentence-a number of months or years declared in advance by a judge-is the measure of retributive punishment. Retribution occurs, if at all, at the sentencing phase, in the courtroom. A prisoner's sentence, however, may be largely a function of the particular judge, or the particular year when he went to trial. Crime that brought 3-to-9 years in 1970 may bring 10-to-30 twenty years later. And in the future, because of prison overcrowding and court-imposed limits, sentences may again decrease. "This is a bad thing," observed Dr. Vincent Reynolds, Chief Psychiatrist at Maximum, a separate facility which shares a common wall with Central and houses the most difficult prisoners or those who need protection. "It sends a message to the inmates that punishment is political." For inmates living together at Central, serving vastly different sentences for committing the same crimes, the quantity of time sentenced can be little measure of retribution.

Retribution is more than a measure of punishment. It is also a justification and a purpose. Although justifications and purposes of punishment are closely related and often merged, they are distinct. ${ }^{31}$ The justifications of punishment are its grounds: Why are we warranted in imposing it? The purposes of punishment are its ends: What do we aim to achieve by it?

Why is punishment deserved? Some legal or analytic retributivists, like J.D. Mabbott, insist that a criminal's punishment is justified because he has committed a crime. Traditionally, retributivists reject deterrence because it may justify punishing the innocent if the social gain is great enough. But when forced to justify punishment for breaking unjust laws, a retributivist can sound very much like a utilitarian: "The effect of punishing good men for breaking bad laws is that fewer bad men [will] break good laws." 32 Thus the analytic retributivist categorically rejects ever convicting the innocent, but refuses to define "innocent" in moral terms, insisting simply that a person be punished after committing a crime for which he has been convicted.

What is important here-the actual commission or the conviction? Many prisoners who are in fact guilty, proclaim their innocence, especially when that claim, if believed by the right people, may result in their release. The fact remains, however, that ours is a system rife with

31. See J. HALL, supra note 8, at 296-97.

32. J.D. Mabbott, Punishment, 48 Mind 152, 155 (1939). Mabbott, however, rejects this approach as "indefensible," instead concluding-unconvincingly-that judges must apply even bad laws because they have "no right" to do otherwise. Id. at 157. 
error. ${ }^{33}$ A defendant with a prior criminal record, casually picked out of a lineup, represented by an overworked court-appointed lawyer who neither believes the defendant's true exculpating story nor believes that a jury will believe it, may well end up inside Lorton Central, convicted of a crime he did not in fact commit. He may be a hustler; he may have committed a hundred crimes for which he was never apprehended, but he may not have committed the specific crime for which he was convicted. An analytic retributivist who insists that punishment is deserved, but only as a penalty for a past crime actually committed and for which the prisoner has been convicted, must insist that the punishment in such a case is undeserved.

Prisoners in Lorton Central typically focus on how they were caught and tried. They maintain that although they may have committed the crime for which they were convicted, if the Government did not "get them right"- catch them and convict them fairly and in accordance with the law-then they do not deserve to do time. Inmate Henry Daniel complained about his conviction for possessing narcotics-narcotics which the police could not find and therefore fabricated: "Yes, I think they cheat; they play with a marked deck. If a dude do something wrong and they catch him with his hand in the cookie jar, then they suppose to punish. He don't have no right with his hand in the cookie jar. If they had caught me right, then I say 'Hey what can I say.' I take my chances. I live with it."

A moral retributivist, however, who ultimately justifies a criminal's punishment by his evil, willful choice to harm an innocent victim, might support punishment, even by a procedurally defective system, so long as the accused has committed some crime for which he otherwise deserves to suffer. Such a false conviction may be poetic justice, or-as inmate Robert Moffitt ruefully characterized his conviction for a crime he denies-"it's the past catching up with you." They have a saying inside Lorton Central: "Maybe you serve time not for what you have done all the time, but all the time you serve, you serve time for what you've done."

When it comes to the purpose of punishment, moral retributivism runs into internal conflict. Retributivists who agree that criminals de-

33. Edmund H. Mantell, A Probabilistic Assessment of the Incidence of Erroneous l'erdicts in Criminal Trials: Theory and Implications, 8 CRIM. JuST. J. 267 (1986) (using probability theory to predict that 15 out of 1000 convictions are erroneous); James MicCloskey, Convicting the Innocent, 8 CRIM. JUST. ETHICS 2, 58 (1989) (arguing that the innocent are convicted more often than the public believes-in about 10\% of all cases); see also Hugo Adam Bedau \& Michael L. Radelet, Miscarriages of Justice in Polentially Capital Cases, 40 Stan. L. Rev. 21 (1987) (presenting 350 cases in which defendants convicted of capital or potentially capital offenses were later found innocent); Malcolm, supra note 28, at A18 (citing a case where a person sentenced to death was discovered innocent and released, and noting "the virtual certainty of sometimes executing innocent people"). For a challenge to the Bedau and Radelet study, see Stephen J. Markman \& Paul G. Cassell, Protecting the Innocent: A Response to the Bedau-Radelet Study, 41 Stan. L. Rev. 121 (1988), and for a defense, see Hugo Adam Bedau \& Michael L. Radelet, The .15yth of Infallibility: A Reply to Markman and Cassell, 41 STAN. L. Rev. 161 (1988). 
serve their punishment because they freely willed their past crimes, may differ among themselves as to what good it will do. Some retributivists see pain and suffering as the means for a criminal's atonement. ${ }^{34}$ "[O]nly through suffering punishment can the criminal expiate his sin," 35 wipe the slate clean, come to grips with his crime, or "realize his moral character."36 We impose pain and suffering for his sake: Through punishment, we make him whole. If we are imposing it for the criminal's sake, however, then retribution becomes barely distinguishable from rehabilitation, its apparent antithesis.

Durkheim advocated expiation, but for society's sake. ${ }^{37}$ Through the criminal's suffering we reaffirm our community. ${ }^{38}$ Similarly, Justice Holmes, who found retribution morally repulsive, believed it socially necessary to gratify our feelings of vengeance. Only a prospect of official retribution after due process of law restrains an angry mob, sometimes a majority mob. ${ }^{39}$ But when we impose suffering for the sake of society or the criminal, retribution collapses and becomes just another

34. Plato declared that "those who are benefited through suffering punishment by gods and men are beings whose evil deeds are curable; nevertheless it is from pain and agony that they derive their benefit both here and in the other world, for it is impossible to be rid of evil otherwise." Plato, Gorgias, in The Collected Dialogues of Plato 525b (E. Hamilton \& H. Cairns eds. 1961).

35. H. PACKER, supra note 10 , at 38 . "The retributive view rests on the idea that it is right for the wicked to be punished: because man is responsible for his actions, he ought to receive his just deserts. The view can take either of two main versions: the revenge theory or the expiation theory." Id. at 37.

36. P. BEAN, supra note 7, at 47. Bean attributes to Hegel the idea that repentance is the object of punishment. Id.

37.

In short, in order to form an exact idea of punishment, we must reconcile the two contradictory theories which deal with it: that which sees it as expiation, and that which makes it a weapon for social defense. It is certain that it functions for the protection of society, but that is because it is expiatory. Moreover, if it must be expiatory, that does not mean that by some mystical virtue pain compensates for the error, but rather that it can produce a socially useful effect only under this condition.

Emile Durkheim, The Division of Labor in Society 108-09 (G. Simpson trans. 1933), quoted in S. KAdish, S. Schulhofer \& M. PAulsen, supra note 10, at 191.

38.

We may look upon punishment as a form of communal expression. An organized group, like an individual, needs to give vent to its feeling of horror, revulsion or disapproval. ... It is one of the functions of the criminal law to give expression to the collective feeling of revulsion toward certain acts . . . . By and large such expression of disapproval is a deterrent. But deterrence here is secondary. Expression is primary.

Cohen, supra note 10, at 1017.

39.

If people would gratify the passion of revenge outside of the law, if the law did not help them, the law has no choice but to satisfy the craving itself, and thus avoid the greater evil of private retribution. At the same time, this passion is not one which we encourage, either as private individuals or as law-makers.

Oliver Wendell Holmes, The Common Law 36 (M. Howe ed. 1963). Holmes, of course, was not the first to believe this. Machiavelli, for example, observed:

[I]t is useful and necessary for republics to provide with their laws a means of expression for the wrath that the multitude feels against a single citizen, for when these 
utilitarian purpose of punishment. ${ }^{40}$

A pure retributivist may reject as irrelevant any benefits accruing from the criminal's punishment. It makes no difference, this retributivist insists, whether it seems that we owe it to him or he owes it to us $^{41}$ : Ultimately, a criminal's punishment is neither for our sake, nor for his; it is deserved and demanded even when it serves neither us nor him. Many critics, including psychiatrists, criminologists, and especially prisoners, find this pure retributivism pointless and cruel.

"What for? What purpose does it serve?" scoffed David "Itchy" Brooks, sentenced to life for a murder he vigorously and plausibly denies. "You can't do nothing but make me mad if you keep your foot on my neck. When you let me go home I'll be twice as ferocious as when you put it on me. So what's the point? What you trying to do? Get me to kill somebody else instead of you?"

The pure retributivist counters that Itchy himself misses the point. Retribution is warranted ultimately because the past crime must be redressed, not because of any future benefits attaching to the criminal's pain and suffering.

With very few exceptions, officers as well as inmates inside Lorton Central denounce retribution. "What about the idea that bad people have done bad things and should be made to suffer?" Sergeant James Edmonds was asked.

"Everybody wants their pound of flesh."

"But isn't society entitled to it?"

"No," he answered. "Because, what is going to make you any differ-

legal means do not exist the people turn to illegal ones, and without a doubt the latter produce much worse effects than do the former.

For, when a citizen is legally oppressed, even if this be unjust to him, little or no disorder in the republic follows .....

Niccoló Machiavelli, The Discourses, in The Portable Machiavelli 194 (P. Bondanella \& M. Musa trans. 1979).

40.

In its most interesting form modern retributive theory has shifted the emphasis, from the alleged justice or intrinsic goodness of the return of suffering for moral evil done, to the value of the authoritative expression, in the form of punishment, of moral condemnation for the moral wickedness involved in the offence. ... But this form of theory has also at least two different forms: in one of them public expression of condemnation of the offender by punishment of his offence may be conceived as something valuable in itself; in the other it is valuable only because it tends to certain valuable results, such as the voluntary reform of the offender, his recognition of his moral error, or the maintenance, reinforcement or "vindication" of the morality of the society against which the person punished has offended. Plainly the latter version of reprobation trembles on the margin of a Utilitarian theory.

H.L.A. HART, supra note 25, at 235.

41.

It hardly matters which aspect of the theory is espoused. The result is the same. The criminal is to be punished simply because he has committed a crime. It makes little difference whether we do this because we think we owe it to him or because we think he owes it to us. Each theory rests on a figure of speech.

H. PACKER, supra note 10 , at 38 . 
ent from this guy? He wants his pound of flesh, he goes out and he takes it at gunpoint. Then you in turn want your pound of flesh. So you want to starve him, chain him, beat him. What makes us any different from them then?"

"We don't hurt him until he hurts us, but he hurts us whether or not we hurt him. That's the difference! The difference is, we may take out an eye just like he did, but we don't take out an eye unless and until he does."

"But you still lost the eye and you still perpetrate the crime. Even if you use the law to do it with," Edmonds countered.

"But his victim may be dead. A family doesn't have a kid anymore, a brother anymore, and the killer's playing basketball every day, making sure he's got his drugs, watching the Washington Redskins on color TV. I describe this portrait to people and they don't believe it."

"I know."

"They ask me, "Is that punishment?" "

"I understand what you are saying," Sergeant Edmonds conceded. "But I strongly believe that if a person is apprehended by the law, given his day in court, comes before a jury of his peers, and they say 'you are guilty,' the judge using the laws on the books tells this man 'you are sentenced and in the custody of the Department of Corrections for a period of ten-to-thirty years,' that's the punishment. ${ }^{42}$ Sure, there's going to be hurt on the part of the victim's family. But for us as a society to want to reap even more revenge on this person makes us the same kind of person he is, just in a different fashion. What would you want to do? We cannot return to the age where you put the ball and chain on him, scourge him with a cat tail. We could never go back to that. I don't know the answers, but I know damn well that's not it."

"You think this place should rehabilitate and correct," Administrator David Roach was challenged. "There's a part of me that's saying'Hey, these guys have done bad things; they deserve to be punished."

"The punishment should not be re-punishment," Roach replied. "The punishment is given in the courtroom, in the criminal justice process. When the judge says 'You have been found guilty; you are sentenced to thus and so,' that's the punishment. The judge did not send them here, in my opinion, for me or anyone else to punish them."43

42. The inmates' statements presuppose that the pain of incarceration is separable from the conditions experienced on the inside, i.e., that "punishment" principally consists in their forced absence from the streets. However, prison as punishment wholly apart from the conditions inside may not exist. See note 16 supra and accompanying text (noting that the number of years of punishment has become the punishment, rather than a measure of the duration of punishment). Although he had little sympathy for retribution and no sympathy for corporal punishment, Foucault observed that "a punishment like forced labour or even imprisonment-mere loss of liberty-has never functioned without a certain additional element of punishment that certainly concerns the body itself: rationing of food, sexual deprivation, corporal punishment, solitary confinement." M. Foucault, supra note 26, at 15-16.

43. To a retributivist like Professor Newman, this shift of responsibility merely com- 
Inmate Pete Arnold rejected retribution in almost identical terms: "Some people operate from the notion that we were sent here to be punished. But your being sent here is the punishment. Now they have read into that they have a responsibility to do other shit to you that's not in the contract." 44

In reality, a prisoner's punishment is his total experience of prison, which varies in intensity as well as duration. Retribution requires that the pain and suffering of a prisoner's daily life inside prison depend on the seriousness of the crime committed outside, on the street. Retribution thus may serve sometimes to limit punishment: The retributive principle-that punishment should be imposed proportionately to the gravity of the offense or the moral depravity of the offender-has as its necessary corollary that punishment shall be imposed on an offender only in proportion to his offense.

Deuteronomy expressed this principle: "The fathers shall not be put to death for the children, nor shall the children be put to death for the fathers; every man shall be put to death for his own sin."45 The Magna Carta implies this limiting aspect of retributivism when it declares that "[a] free man shall be amerced for a small fault only according to the measure thereof, and for a great crime according to its magnitude." 46 Kant briefly hinted at this, but H.L.A. Hart developed the idea of retribution as a limit on punishment which he called "retribution in distribution"47: All and only the guilty shall suffer but their pain and suffering shall only be in proportion to their crimes. ${ }^{48}$ Distributive retributivism, then, complements but does not capture the spirit of an affirmative retributivist who demands the criminal's pain and suffering, not as a limit to avoid something worse, but as itself necessary and proper.

In theory, prison life should be tougher for serious felons, and by privileges and courtesies extended, it should be relatively more comfortable for less serious offenders. But inside Lorton Central, theory and reality do not match.

pletes the process begun in the courtroom: "The judge may now rest easily on his numerical sentence without having to refer directly to the source of its real meaning, which should be pain (whether chronic or acute) concretely felt." G. NewMaN, supra note 16, at 75.

44. "It is sometimes said that criminals are placed in prison not for punishment but as punishment ...." G. SYKes, supra note 15, at 31 .

45. Deuteronomy 24:16.

46. EnG. Magna Carta $\S 20$.

47. See H.L.A. HART, supra note 25, at 9-13.

48.

The need for retribution justifies the punishment of offenders, but the amount of punishment is limited to the amount of punishment necessary to achieve the retributive effect. . . . The notion that the punishment should fit the crime, and not grossly exceed it, is one natural limit on the imposition of sanctions for deterrent purposes.

Franklin E. Zimring, Perspectives on Deterrence 21, 24 (1971); see also P. Low, J. Jeffries $\&$ R. BONNIE, supra note 6 , at 4 ("the concepts of blameworthiness and proportionality may be seen as limiting the occasions for, and severity of, punishment that is otherwise justifiable on purely utilitarian grounds"). 
Inside Central a man's crime is virtually ignored. Officers routinely deny that they treat a prisoner with an eye to his record, to his crime, to his "evil" choice that brought him to prison. Captain Frank Townshend, a long-time, well-respected, tough-but-fair officer, insisted that he never looks at a man's record when he deals with him lest he be "prejudiced. Everyone is entitled to the same treatment here, regardless of what they did to get here. What a man is in here for is not our concern."

"Do you read their records?" Sergeant Cody was asked.

"I am not here to do that."

"You don't care what a guy has done to get in here? It makes no difference to you what he has done out there?"

"No difference. He has been to court and he has been sentenced and that is that. I am just to keep him safeguarded by the process of law."

All officers interviewed agreed: They never consult a man's record, and sometimes for good reasons. "If you know a man is a murderer, you may fear him, and he will sense that. They pick up those things," said one officer, "so I don't want to know. I make it a point not to know." One female officer offered a similar rationale. She does not check the records, for if she discovers a man is a rapist, she will feel apprehensive about disciplining him. Even when officers do know the criminals' records, they do not treat the more serious offenders more harshly. Rather, they concentrate on behavior which may cause problems in prison. "Inside, a thief is more dangerous than a murderer," observed Sergeant Shipley. "The thief will continue to steal whenever he can, and get himself or someone else stabbed or killed. So he's the one, day to day, that you have to come down hard on."

The inmates confirm this and feed into it. Johnny Allen, for example, used to tell officers, "I break laws; I don't break rules: I'm not going to make your job harder, so you don't make my bit harder."

Overwhelmingly then, by their actions and attitudes consistent with official D.C. Department of Corrections policy, officers and inmates reject retribution as a goal of punishment on the inside for past conduct on the outside. ${ }^{49}$ To them, the judge metes out punishment by setting the number of years during which all inmates will be equally deprived of liberty. The officers see no point in trying to make prison more painful for prisoners because they "deserve" it, unless they deserve it for their conduct inside prison. By consciously ignoring prisoners' criminal records, however, officers unwittingly help sever the essential retributive connection between the past crime committed and the present punishment experienced. As Captain Townshend said, "It's none of

49. A few prisoners would prefer that treatment reflect the crime committed. "The most petty crime and the most heinous crime results in the same punishment in Lorton," Henry Daniel complained. "The same lifestyle. There is no variation according to the crime." 
my business. What a man is like in here is what I'm concerned with, not what he did out there." 50

The prisoners further help cut all connection between crime on the street and punishment inside the joint. With the exception of rape which they scorn, and child molestation or crimes against the elderly for which a prisoner may be ostracized or physically attacked, whatever a person did on the outside is his own business. ${ }^{51}$ Each man is a hustler, trying to survive.

While officers and inmates largely reject retribution, denying that additional pain and suffering is warranted, they insist that for the criminal to be inside Lorton Central is retribution enough. Old-timers like Wade Briggs, however, complain that to the younger prisoners life inside prison is "pretty much the same as on the street. Their little honeys can come and see them; they can sneak off and have a little sex here and there. Drugs when they want, get drunk when they want. They can have personal clothing so they can dress similar to the way they did in the streets. Get up late. Pretty much the same thing as at home. Somebody to look out for them." The retributivist is appalled.

"On Friday nights between six and eight everyone's bar hopping. Between nine and ten, everyone's trying to get their drugs to go with the wine. Almost every night, but especially Friday, guys be standing on the walk staggering. You'd think you're at a damn party," said Johnny. "Guards don't say nothing except 'Hey Mac, you're drunk again.' The joint is just so sweet to them."

The retributivist is furious. Recall, however, the pain and suffering which moved the older inmates to call Central a "death trap," a "hell hole." Boredom, ${ }^{52}$ anxiety, and fear pervade the institution. However haphazard and unofficial, this is the characteristic pain and suffering of daily life inside Lorton Central.

50. Sykes found similar results in another prison. "[T]he administrators of the New Jersey State Prison have no great interest in inflicting punishments on their prisoners for the crimes which they committed in the free community, as paradoxical as it may seem." G. SYKES, supra note 15, at 31 . "[O]fficials ... rarely turn to the behavior of the captive before he entered the institution as something for which atonement must be secured." Id. at 33 .

Sergeant Shipley summed up the attitude of the officers at Lorton: "The only difference between a man running around here and a man behind the wall, locked up in maximum security, is not the crime he committed out there, but the attitude he has while he's in here."

51. E. Goffman, supra note 19 , at 67 (noting the "almost universal delicacy when it comes to inquiring into another man's misdeeds, and the refusal to determine one's relations with another convict on the basis of his record") (quoting R. Alfred Hassler, Diary of a Self-Made Convict 116 (1954)).

52. Dr. Reynolds, a rare staff member who supported retribution, explained that "the most important weapon to this prison system is boredom. By the time a prisoner spends a year in 2-block, he becomes very boring to himself. It becomes a terrible burden to him. If you are spending a lot of your time doing absolutely nothing, that will get to you. That's all we can do anymore. There used to be ways that prisons could punish people, but basically courts have decided that these are cruel and unusual punishments. Although this is not something people generally talk about, the fact is, boredom is the principal instrument of punishment here." 
But such pain and suffering cannot satisfy a retributivist. And not only because it may be insufficient or unofficial, but because it is not proportional to the crime committed. There are limits to deserved punishment, and a retributivist must oppose all unwarranted pain and suffering from whatever source. ${ }^{53}$

Inside Lorton Central, then, those who suffer most often deserve it least. The toughest criminals who committed the worst crimes have it easiest. They have moved up to supervisory positions in industry, making the best money for the least work; they have the best hustles going; they have the established contacts for drugs, weapons, and other goods and services. And they "push steel" (stab with a "shank") most effectively, terrorizing the timid, short-term first offender, who deserves the least and suffers the most.

\section{B. General Deterrence}

In punishing wrongdoers, no one concentrates on the fact that a man has done wrong in the past, or punishes him on that account, unless taking blind vengeance like a beast. No, punishment is not inflicted by a rational man for the sake of the crime that has been committed-after all one cannot undo what is past-but for the sake of the future, to prevent either the same man or, by the spectacle of his punishment, someone else, from doing wrong again.

$$
\text { - Plato, Protagoras }{ }^{54}
$$

Deterrence lies at the very source of Western culture. Although the Old Testament is retributive in its measure of punishment-an eye for an eye-it is fundamentally deterrent in its justification and purpose. Over and over, the Bible calls for harsh punishment, not only because an individual deserves it on account of his past transgression, but also for the future benefit it will bring to others ${ }^{55}$ : "[T] hen you shall do to him as he had meant to do to his brother .... And the rest shall hear, and fear, and shall never again commit any such evil among you." 56

53. Unwarranted suffering is not identical to unintended suffering, for a retributivist may embrace an inmate's actual suffering, however unofficial. This depends upon a coherent notion of desert, about which the literature is massive. For an insightful, recent discussion, see Lloyd L. Weinreb, Desert, Punishment, and Criminal Responsibility, 49 Law \& ConTemp. Probs., Summer 1986, at 47.

Some retributivists, like Mabbott, apparently believe that "unofficial" pain and suffering is not part of the retributive equation, leaving it unclear whether that rejection stems from its unofficial and therefore unintended character, or its unwarranted extremity. "When a man is sentenced to imprisonment he is not sentenced also to partial starvation, to physical brutality, to pneumonia from damp cells and so on." Mabbott, supra note 32, at 165.

54. Plato, Prolagoras, in The Collected Dialogues of Plato, supra note 34 , at $324 \mathrm{~b}$; see also PLATO, Lau's, in id. at $854 \mathrm{~d}$ ("For truly judgment by sentence of law is never inflicted for harm's sake."). Plato also wrote: "The purpose of the penalty is not to cancel the crimewhat is once done can never be made undone-but to bring the criminal and all who witness his punishment in the future to complete renunciation of such criminality ..."Id. at $934 \mathrm{~b}$. 55. "[T] hat man shall die; so you shall purge the evil from Israel. And all the people shall hear, and fear, and not act presumptuously again." Deuteronomy 17:12-13.

56. Deuteronomy 19:19-20. 
Throughout the centuries deterrence advocates have attacked retribution as foolish and barbaric. "That which is past is gone, and irrevocable," insisted Francis Bacon, disparaging revenge, "and wise men have enough to do, with things present and to come; therefore they do but trifle with themselves that labor in past matters."57 "Can the groans of a tortured wretch recall the time past, or reverse the crime he has committed?" Cesare Beccaria asked in 1764, in his essay On Crimes and Punishments. "The purpose of punishment, therefore, is no other than to dissuade the criminal from doing fresh harm to his compatriots and to keep other people from doing the same."58 In other words, don't cry over spilt blood.

Prisoners at Lorton agree. Even in defining retribution inmate Pete Arnold slipped into a deterrence frame of mind: "Retribution is when the state sits back, licks its chops and says 'alright motherfucker, let's see who else wants to do this."

In theory, deterrence is simple. "[T]hreats can reduce crime by causing a change of heart, induced by the unpleasantness of the specific consequences threatened."59 Commentators, however, have long observed how difficult it is to demonstrate a punishment's actual deterrent effect. ${ }^{60}$ We cannot isolate a threat of punishment from many other reasons that noncriminals do not commit crimes. Traditionally, critics have pointed to overcrowded prisons and high crime rates as proof that deterrence fails. Supporters of deterrence counter that prisons are the last place to look for those whom punishment successfully deters.

According to the psychology expounded by Beccaria and Bentham, a rational pleasure seeker defers immediate illegal gratification because a threat of future punishment weighs decisively in his pleasure/pain, cost/benefit calculus. ${ }^{61}$ Convicts as well as commentators dismiss this

57. Francis Bacon, Of Revenge, in The Essays, or Counsels, Civil and Moral, of Francis Ld. Verulam 21 (n.d.).

58. Cesare Beccaria, On Crimes and Punishments 23 (D. Young trans. 1986) (6th ed. 1766), reproduced in part in M. COHEN \& F. COHEN, supra note 10, at 348 (slightly different translation).

59. F. Zimring, supra note 48 , at 3.

60. Zimring, who defines "the deterrent effect of a particular threat" as "[t]he total number of threatened behaviors it prevents," observes that " $[t]$ he potential bank robber may respond to the threatened penalty for bank robbery by switching to burglary ..." Id. at 2 . Many inmates revealed that they had switched from bank robbery to drug dealing, in part because of the increased probability of being apprehended for bank robbery. Dr. Gregory Zilboorg presents a common view of deterrence critics: "No realistic results can be brought forward to support the claims of the principle of 'the deterrent effect.' We have only our inalienable faith that man can frighten man into decency." Gregory ZlLboorg, The Psychology of the Criminal Act and Punishment 27 (1954).

61.

In order for a penalty to achieve its objective, all that is required is that the harm of the punishment should exceed the benefit resulting from the crime. Further, the inevitability of the punishment and the loss of the anticipated advantage of the crime should enter into this calculation of the excess harm. Everything more than this is superfluous and therefore tyrannical.

C. BecCaria, supra note 58, at 46, reprinted in parl in Sawyer F. Sylvester, JR., The Herttage 
psychology of the rational prudent calculating maximizer as fantastican ideal inapplicable to the streets: General deterrence is unreal and unworkable; people do not consciously weigh costs and benefits before they engage in crime. ${ }^{62}$

A litmus question to the inmates at Lorton Central- "Before you pulled the trigger [or robbed] did you ever think about what would happen if you were caught?"- - revealed minds unconcerned with future punishment in moments immediately surrounding the criminal act:

"Nah, never thought about it," said inmate David Basnight, "until one time, and that's probably why I got caught. I just stood there, looking at the camera, thinking."

"Did you ever think about getting caught?" inmate Harry Rowe was asked.

"No."

"Never occurred to you?"

"No."

"Never thought about going to jail?"

"Well, I'd been told, but you know, I ain't never really thought about it ...."

"And the day you did it, it never passed through your mind that 'Hey, I might get caught, this might be the last day'?"

"No, I ain't think ... that weren't on my mind. Just getting the

of Modern Criminology 20 (1972) (slightly different translation). Bentham followed Beccaria's emphasis on the rational calculating maximizer. "In all cases of offence there is a calculation of the chances for and against; and it is necessary to give a much greater weight to the punishment, in order to counterbalance the chances of impunity." JEREMY BENTHAM, Theory of Legislation 326 (4th ed. 1882), reproduced in part in M. Cohen \& F. Cohen, supra note 10 , at 333 .

62. "Criminals who are tempted will not ... desist from taking a risk just as wolves who attack a wild horse on the Russian steppes will not abandon their effort after one or two of them are killed or crushed by the horse's hoof." Cohen, supra note 10, at 1015.

Perhaps the leading contemporary advocate and analyst of deterrence is Johannes Andenaes:

Two extreme positions often emerge from the literature on the subject. One is the position of Jeremy Bentham, who considered man to be a rational being choosing between possible modes of action on the basis of a calculation of risks of pain and pleasure. The consequence of this model is clear enough: If we make the risk of punishment sufficient to outweigh the prospect of gain, the potential lawbreaker will, as a rational man, choose to stay within the limits of the law.

The other extreme, often represented by psychiatrists, discards this model as unrealistic. When people remain law-abiding, they maintain, it is not because of fear of the criminal law, but because of moral inhibitions or internalized norms.... In my view, both extremes are equally mistaken, or to put it in a more friendly way, each represents only part of the truth.

Johannes Andenaes, Punishment and Deterrence 110-11 (1974); see also J. Kaplan \& J. Skolnick, supra note 10, at 60-61:

The belief in the value of deterrence rests on the assumption that we are rational beings who always think before we act, and then base our actions on a careful calculation of the gains and losses involved. These assumptions, dear to many lawyers, have long since been abandoned in the social sciences. 
money and getting away."63

The pressing problem of the moment-getting away-includes not getting shot, and not getting caught, which may subconsciously include a future trial and eventually a prison term. But conscious calculation is not so much of punishment as of pulling it off and escaping.

"Did you ever think about getting caught before you did the things you did?" Johnny asked inmate Anthony Chandler Bey.

"Nah, only afterwards."

"Were you aware of the type of sentences other people were getting for robbery?"

"No."

"If you had been aware of the large sentences, would it have stopped you? Would it have made you stop and think about it?"

"Yeah, it would have made me stop and think."

"Would it have stopped you from doing the crime?"

"I don't think so. I think I would have been more aware. Wouldn't just go up and do it. Know what's happening. Look it over first. I think being aware of the sentence part, then I would have looked more deeply into it."

"Seeing another hustler fall, you say 'he did something foolish," something you're not going to do," mused Itchy Brooks. "Sometimes a guy try to find out what he did so he won't do the same. That's the only deterrent effect that has."

When the possibility of being caught only causes a more disciplined hustler to take greater precautions or to switch to safer crimes, has deterrence succeeded?

Some criminals may be undeterrable because they do not calculate, but others are undeterrable because they do. "I had a job," said inmate Wade Briggs, "but I saw that the same amount of money it took me four weeks to work for, I could make in one day."

"They were going to put me in the army," declared Itchy, "but I figured why go six thousand miles away to kill someone, and put your life in jeopardy for a principle you might not even agree with for one hundred fifty dollars a month, when you can place your life in jeopardy for a much shorter period of time at the bank, and when you get away with it you can live well for awhile. It makes no sense.

"If I worked, there wasn't much chance of my getting more than a few thousand dollars a year and here's a chance of my getting two hundred fifty thousand dollars in a day or so. It was worth it to take the risk. Plus the federal statistics show that only a little over half of all

63. "A special problem in the communication of information about threat and punishment is that of bringing these considerations to the attention of potential law violators at the time that decisions about law violation are to be made. The moment of truth in the life of a potential deviant seldom takes place in the local law library." F. ZimRING, supra note 48, at 6061 . 
bank robbers are caught. And eighty percent of those just ran in and grabbed the stuff. People in the banks are instructed not to create the kind of situation where somebody's going to get hurt. Because the money's insured. And really the professional is not going there to hurt nobody. He's going there to get the money. Since he knows they're instructed not to offer resistance, that's the way it's done."

And yet Itchy, who admitted he had not been deterred in the past, insisted nevertheless he was someone "who thinks of punishment and rewards. We put it on a scale and weigh it." Not that the logic of deterrence has failed for Itchy and other calculating maximizers, but rather the risk/reward ratio makes it a good gamble. "The risk for the lawbreaker must be made so great, the punishment so severe, that he knows he has more to lose than he has to gain from his crime," 64 wrote Johannes Andenaes, a leading deterrence theorist. For deterrence to work, detection must become more probable, punishment more swift, certain, perhaps harsh and-what is often forgotten-the freedom lost must be seen as valuable. "A person have to have something that you take away from them," observed inmate Leo Simms, "but if you don't got nothing, or consider what you have of any value or any importance, then you ain't took nothing from them." 65

Even hustlers who have something to lose do not think they will lose it. The "I never thought it could happen to me" attitude is embedded in human nature and transcends the issue of crime, although it directly affects deterrence. ${ }^{66}$ Some criminals do weigh costs and benefits, but use distorted measures. Love boat, a drug of choice in the streets of Washington, D.C. and inside Lorton Central, typically makes a person feel omnipotent, seriously distorting his calculations.

Then there are the more accurate calculators, whose self-confidence and careful planning make each criminal act seem worth the risk, yet whose sense of realism does lead them to expect apprehension and punishment someday-but never today. This attitude is characteristic of professional criminals. "In the system we're living in, in Washington," said Charles McCulloch, "if you're hustling, you're going to jail. It's that cut and dry. If you're hustling, you're going to jail." 67 "Jail is part of hustling," said Johnny. "That's something that all hustlers understand. I don't know a stickup man yet that hasn't been to jail. You know you're going to fall sooner or later. Something's going to happen, one way or another. Something you do or something that somebody else does. It's part of the game."

64. J. ANDENAES, supra note 62 , at 7 .

65. "The spread of personal liberty made it possible to view the loss of liberty as a serious deterrent." G. SykES, supra note 15 , at xi.

66. "It is often said that criminals tend to be overly optimistic-they are confident that all will work out well." J. ANDENAEs, supra note 62, at 52.

67. "A professional criminal may be so strongly involved in his profession that he feels there are no real alternatives regardless of the penalties." Id. at 56 . 
Moreover, for some criminals the risk of getting caught and punished is part of the thrill-an inducement to crime. "To me, hustling is a complete turn on, it's excitement, it's the challenge," said Wade Briggs. To pull off a good robbery-lots of money, a show of force, no one gets hurt, a clean getaway, and later dividing the spoils-is for many criminals a "real high." The fear of punishment only heightens the excitement. ${ }^{68}$

Thus, for both calculators and noncalculators, with a narrow focus on the criminal's mental state in moments immediately surrounding the criminal act, getting caught, much less the punishment afterwards is, in the words of Itchy, "not even a consideration because I picked out what I'm going to buy before I even go in."

Contemporary deterrence advocates like Andenaes and Professor Zimring flesh out a supportive psychology beyond the conscious: Without rational calculation, vague fears of punishment inculcate in a would-be criminal a habit of and positive attitude toward lawful behavior, thus at least subconsciously deterring the timid. ${ }^{69}$ Thoughtful hustlers like Johnny also realize that when another criminal is arrested or punished, deterrence may consist of a subtle, subconscious change of attitude toward one's own lifestyle. "How about the person that's hustling, or starting out hustling, that see this other guy doing well hustling, and then witness this guy's downfall?" Johnny asked. "Say you're a good hustler and I'm laid back and I'm watching you, and all the things that you are, I want to be. All the things that you got, I want. So, I know that you got thirty people on the street selling narcotics. Now you get busted. They give you fifteen years. Now, do that shatter my dreams of being like you? Do that stop me from wanting to be like you, wanting to have the things that you have? Do that stop me in any way?"

Inmate James "Pete" Arnold restated the question before answering it: "An individual who likes me, who have heard of me, who been around me, seen me lay one hundred dollar bills on the counter, and young girls, put them in my car; every time he sees me I got a five hundred dollar suit on, or a thousand dollar watch-whether putting the individual away who sets the example will deter the individual who's following him, I doubt it very seriously. I doubt whether the punish-

68. "It is also possible, of course, that the very severity of the penalty-the magnitude of the risk-may give the illegal action a special appeal, in the way that dangerous sports are attractive to some people." Id. Freud identified another type of person who is not deterred by the threat of punishment: "[C]riminals from a sense of guilt" commit their crimes "principally because they were forbidden, and because their execution [is] accompanied by mental relief for their doer." SIGMUND FREUd, Some Character-Types Met with in Psycho-Analy'ic W'ork (1916), in 14 The Standard Edition of the Complete Psychological Works of Sigmund FREUD 309, 332 (J. Strachey trans. 1957).

69. "The lawyer ... can easily lose sight of the irrational factors in human motivation and construct psychologically superficial explanations, based on a view that crime grows out of conscious, rational consideration as to what is most profitable." J. ANDENAES, supra note 62, at 6-7. 
ment, unless it's death, will have a profound impact on the follower, unless the follower has had an intimate relationship with the leader or the person who he aspires to follow. The individual who goes behind generally doesn't realize the consequences that will have to be paid in the end. It's the person who takes those chances who really knows. The person who's following is not as mature as the person who's doing it. It's more or less of a movie to him. So he's fantasizing about this shit he's seeing."

Sergeant Edmonds saw it much the same way. "He is still a hero. Even if they come to jail, he's here. He is their hero."

"But if he is going away, doesn't his getting in trouble have any effect on the way they perceive him?"

"No, it does not diminish his hold on them and how they see him. Kids even make excuses for him: 'He took a bum rap; the police jammed him.' Never 'This guy did something wrong; he should be punished." "

"People are driven to crime by being bombarded by images on television of the lifestyle a successful person must lead," observed inmate Reggie Brooks. "They don't understand that they have to have longrange goals. They grow up, taking it for granted that they need it, and must have it, without learning what it takes to get there. That lifestyle takes many years and much effort. But long-term goals are surrealistic. I mean you can chase it for ten or fifteen years, and some people can try to keep their eyes on it, but along that path, you'll be confronted with a lot of short-term opportunities. The long range goal is just something that you're told should be there. It doesn't come into reality. Or at least he can't see it come into reality. Life teaches us that the long range goals are bullshit and it's the short range goals that really give you the rewards. So they take the short way in."70

"The average black kid in the ghetto after that first knockdown knows that the old bootstrap trick is not really there," observed Sergeant Edmonds. "And he just takes a look around at his aunts and uncles, his parents and cousins, and he assesses how far they reached up this ladder of success. How much have they gained? And he is saying to himself 'Gee they don't got very much, old raggedy clothes, living in a run-down dump.' Then he looks right across the street. Here Joe Slick pulls up: He's got this great big shiny car, the best looking

70.

One weakness in the mechanism of deterrence is the fact that threats of future punishment, especially if apprehension is uncertain, do not have the same motivating power as the desires of the moment. While some people live in a state of perpetual anxiety and concern for the future, others focus only on the present. There have always been people who have been willing to risk eternal pain as the price of satisfying worldly desires in this life. Moreover, when the risks of detection are considered small, it is possible that questions about the severity of the penalty tend to lose their significance.

Id. at $\mathbf{5 5 .}$ 
clothes on, he's got his jewelry on, he's got a fine looking woman with him. The guy says 'Now that's what I want,' because this guy's got it. $\mathrm{He}$ is not equating that with the whole picture, but he is looking at the for-now. If you watch guys when they come to jail, they come back with the stories of the fast, the good: 'Man you should have seen me. I had this bad set of wheels, I had this little freak girl. We were rolling.' It's that for-now that I think has swallowed them up."

Beccaria and Bentham were not wrong to emphasize that future pain will be discounted by its improbability and remoteness. But so too is delayed pleasure. The image of the fast lifestyle is the lure. Longdelayed benefits seem immediately attainable, long-term sacrifices, as Reggie Brooks observed, are "surrealistic. Unless you have some influential role model before you, it's much easier to yield to the immediate gain-the way into the car now, or the house now."

In the grand tradition of the ancient sophists, under a theory of general deterrence, appearances and images have replaced reality and experience. Bentham urged that "[i]f hanging a man in effigy would produce the same salutary impression of terror upon the minds of the people, it would be folly or cruelty ever to hang a man in person."71 Philosopher Morris Cohen observed "that all men live more or less in their imagination."72 Thus, images of what has happened to their street heroes after getting caught, and what awaits those who follow in their footsteps, can become the basis for deterring inner city youth.

Sergeant Edmonds uses such images of Maximum - "the prison's prison"-to scare visiting school children. "They hear gates lock behind them. . . CB-2 [cell block two] has the most profound effect of anything we have done or said to them. Just to see it. Just to go there, to walk through it. Guys with all the macho bullshit, when they go up in there, it shakes them. To see how these people are living, confined to these little cells, more than twenty three hours a day." Some potential criminals seeing this prison for themselves, and imagining the lifestyle inside, do heed the pleas of prisoners not to hustle. But, as Pete Arnold had observed, the greatest deterrent effect comes from witnessing the pain of loved ones. Family visits at Lorton could provide a most compelling occasion for images and pain to combine and produce maximum deterrence. But they don't.

71. Jeremy Bentham, Rationale of Punishment 29 (1830), cited in J. Hall, supra note 8 , at 312 n.50. "Therefore, punishments and the method of inflicting them should be chosen that, mindful of the proportion between crime and punishment, will make the most effective and lasting impression on men's minds and inflict the least torment on the body of the criminal." C. BECCARIA, supra note 58, at 23.

72. Cohen, supra note 10 , at 1016. In this sophistic, man-the-measure doctrine, subjective perception replaces actual fact in the likelihood, as well as the experience, of punishment. "The decisive factor in creating the deterrent effect is, of course, not the objective risk of detection but the risk as it is calculated by the potential criminal." J. ANDENAEs, supra note 62, at 52. "In short, then, for deterrence to work, a sanction must be real or seem real." J. KaPLAN \& J. Skolnick, supra note 10 , at 57 . 
Sergeant Edmonds reminisced about his first year at the prison: "It was Christmas of ' 80 . We had a tree down in the visiting hall and in the cell blocks. And as the kids came in, the fathers came out of their cells carrying gifts. It was a mixed emotion day for me, to look at the picture we projected to the younger kids when they came here to visit. Just to watch the expression on their faces, how they would light up when they came through the control area out front. We shook them down, brought them inside. They got on the bus, rode down to the visiting hall, their eyes just lit up. They were all aglow, watching this door, waiting for their father to come through that door into that visiting hall. And they just ran to him and flung themselves on him. It made you conscious of your younger existence. And how you felt about your father. My father was in the military, so we had that kind of 'father's home, boat's in!' He's going to be here in a few minutes and everybody is all excited about it. And everybody is rushing to him. It gave me the same kind of feeling watching them.

"But by the same token, it made the children feel that this was a good place, because all the good things that occurred to them in a family sense were occurring right here inside an institution where their father was locked away at. And being punished at. So it did not build a sense of 'this is a bad place;' it built the sense of 'this is a good place'the experience for a lot of them, of seeing for the first time both parents together, hugging and embracing and enjoying each other's company. And the kids running around the visiting hall or out in the field, having a good time with other kids from their neighborhoods within the city. We were giving all the wrong cues and messages here .... We have to project to them that it is not Sunday on the farm all the time. It is not a ride to Grandma's for the turkey dinner. This is a bad place to be.

"I talked to one of the young boys in the visiting hall one day, and he says to me, 'When I come to Lorton, you not going to beat up on me.' And I asked him, 'Well, why would you want to come to Lorton?' And he said, 'Because my father's here.' It was weird to have a child think that way. ${ }^{73}$ Because he really did not understand what it was about. He did not understand the meanness and ugliness of it. After that two hours is up and his father had to go back into the jungle, where he had to fight for his survival until his next visiting day, if he was lucky enough to make it and not get stabbed. Put on his best civilian clothes and come to the visiting hall. And spend another two hours with the family."

"When the kids visit, you give them your best smile," Itchy agreed. "We're relaxed; nothing jumps off at the visiting hall. But they don't see our face change as we leave the hall."

73. "Daddy, how old do you have to be to come here?" Henry Daniel's son asked him one visiting day. "I want to come stay with you." 
"In the inner city, people never speak harshly of Lorton," continued Sergeant Edmonds. "They speak harshly of maybe conditions, of people who run Lorton, but Lorton itself is never uttered in a bad taste. It's never 'there is this terrible hole in the wall down there and this place is called Lorton.'

"Women spend their whole lives coming up and down [Interstate] 95 to Lorton, promising 'If you come back again I am never going to come back down here again.' They come right back. A guy gets out. Sometimes he doesn't even go see her, but once he comes back, they come. It's a psychological thing. If they got a man in Lorton, they got a man, and they know where that man is. 'Where's your man?' 'He's in Lorton.' Or 'what are you doing here by yourself?' 'My man is locked up in Lorton.' You got young ladies who meet men in Lorton, and begin to religiously come to Lorton, even though they never knew this person on the streets," said Edmonds, ruefully. "There are guys here at Lorton who were conceived inside Lorton. That has to be the greatest tragedy of this place."

Exposed in youth to favorable reports of prison life or remembering pleasant prison visits, consumed by the "for-now," lured by images of street hustlers making it in the fast lane-optimistic and uncalculating, or calculating with minds distorted by drugs, or calculating and finding crime worth the risk after all-the prisoners appear undeterred, if not undeterrable. Their experience inside Lorton Central, however, demonstrates that in some respects they are most deterrable.

"Since all the inmates are armed and none of the guards are, what keeps the guards alive?"

"The thought of getting twenty-to-life laying up in Marion," said inmate Robert Dent.

"So the threat is a threat of transfer?"

" 'Feds!' That's all they got to say, that will do it."

"When you think about it, there's thirteen hundred of them, and only fifty of us," Sergeant Shipley observed. "It's their institution. They know they can take it anytime they want to. By the same token they know we're going to get it back." Sergeant Shipley might have added that inmates assume that officers will take it back violently. Oldtimers frequently refer to the "guard riots" of 1968. And on January 20,1989 , when a few inmates set fire to the administration building, some officers went on a rampage, beating prisoners in their dormitories and destroying their property.

So the inmates' momentary preponderance of power on the compound is neutralized by the prospect of transfer or rough treatment at the hands of officers who are likely to retaliate. Threats-images of their own punishment-deter prisoners from assaulting guards.

Daily, inmates are also deterred from committing all sorts of crimes among themselves. Stealing cigarettes or tape players from a locker 
may be tempting, especially when a prisoner needs money for the day's fix. But for the victim, "it's expected that you do something, if it's no more than put wood on his head," Johnny explained. "Otherwise, you leave yourself open for it to be done to you by another guy, and another guy, and they'll carry you further and further." Every day then, deterrence operates inside, as long as a prisoner's reputation is "not going for nothing," which means retaliation will be swift and sure. Fellow inmates respond to this with "respect." Some prisoners, like Itchy Brooks, don't lock their lockers, and yet nothing is stolen from them. ${ }^{74}$ "Sometimes respect centers around reputation," said Johnny. "And if our reputation is not respected, we will carry it to another level, and that is a known fact. Even the foolish people have enough sense to stay clear."

Deterrence also operates among criminals on the street. "I was a hustler who would hustle off fellow hustlers. I would stick up a dope man anytime. It was all part of the game," said Johnny. "But if a guy rip off one of your runners, you may beat him up pretty bad, put him in the hospital, even kill him-not because you hate him, he's a fellow hustler-but to make an example of him." Deterrence works on the street as "[g]reat [r]obbers punish little ones." 75

The length of a prison sentence should affect the level of deterrence. "There was a lot of robbing but not much shooting," said Robert Simms about the streets a few years ago. Simms had broken with a partner "because I didn't like the way he was carrying it .... He would bust a guy's ass if he act like he going to buck, if a nigger even say something. See I ain't going to catch no murder beef and be in this motherfucking joint for the rest of my life, the way they was giving out time then-and now it's even more worser." The thought of twenty-tolife for murder did not stop Ike Cooke from armed robbery, but it did stop him from killing a resisting victim: "Yes, that's exactly what would stop me. That and the hardships that getting caught up would be to my family. They're suffering psychologically and financially because I'm not there." Most older street criminals condemn the kids for their unnecessary violence. "Twenty years ago," said Alvin Hines, "with armed robbery the idea was no one gets hurt. Today, kids will hurt. They

74. Once someone did take three cans of soda Itchy had left in the sink. So he left another two sodas in the sink with a note: "Here's two more; you can get away with it a hundred times; it don't take but once to get caught." When he returned, five cans were in the sink.

75. John Locke, Two Treatises of Government bk. II, $\$ 176$ (P. Laslett ed. 1960). Locke's quote reflects a common complaint of the prisoners-that the less powerful are punished for the same acts that those in power commit with impunity.

Deterrence on the street also occurs when a street seller of narcotics "comes up short," i.e., he doesn't have all the money he owes to his supplier who has fronted him the narcotics. He may be killed as an example. The object is for other street dealers to assume their boss killed him, but for no one to be able to prove it. 
have an intent to hurt. They go in to hurt. The strain they're under. The influence of drugs they are under."

"The whole stickup game has changed," complained Johnny in one of our first meetings. "It's all the way different than it was in my day. For me, to pull a perfect stickup, get the money, make a smooth getaway, and not have to shoot somebody or hurt nobody - that was a groove, that's what got me off. Now things are sloppy: Firing on people for no reason, the least little move, killing them. It's messed the whole stickup game up." It is simply "wrong" to shoot a guy who does not resist: "If it came off smooth with me, that prove something to me. Now if they hurt somebody, it prove something to them." But "wrong" is equated with stupid, inefficient, counter-productive: "It bring the heat down, it just don't pay." The police will investigate shootings more diligently; otherwise robberies often go unreported, or if reported, are dismissed as unsolvable. If you are caught you will go away for longer. And in any event, when word gets out on the street, the victim's family will retaliate, which is why you should never rob someone who knows you. All in all, a threat of future pain and suffering most definitely deters many robbers from hurting their victims.

Professor Heymann initiated this prison study in part to probe for the deterrent effect of longer sentences issued. The inmates generally agree that the longer sentences imposed by the D.C. judges since the mid-1970s have had a profound effect. "The superior court has taken the attitude that 'we're going to load their ass up.' So they send guys into here with ten-to-thirty, sixty-five-to-life. You got to do that front number," explained Pete Arnold. "The prisons now are bursting at the rims with prisoners."

"So do longer sentences affect the people committing crimes outside?"

"Yeah," said Pete. "Because you're not getting turnover. They can't come in when the federal court issues a mandate that the jail population has reached a point where it's explosive and contravenes the eighth amendment. It becomes cruel or unusual. They got a ceiling. They cannot bring any more prisoners in here. You got twice as many people in the streets waiting to come in, guys with five or six charges pending in court: 'sale, sale, sale, possession, armed robbery, armed robbery.' The only one they seem willing to get off the streets is rapists and murderers, and armed robbery but only if there be gunfire or an injury. If I commit armed robbery today or tomorrow, I can't be sent to the D.C. jail."

"So where do you go?"

"You go back home on personal bond and pray that nobody gets released!"

Perversely, then, longer sentences may deter the police from arresting criminals and other officials from jailing them. 
After agreeing with Pete, Johnny, Itchy, and Sergeant Edmonds that deterrence was based on an unrealistic psychology, inmate Reggie Brooks added a sociological dimension to explain its failure ${ }^{76}$ : "Deterrence is a foolish concept, because it has nothing to do with the way things really work out there on the streets. What it's all about is slots. You got a guy, for example, hustling drugs. Now the guy who brings it in gives it to one guy on the street. That guy has eight different people working for him. Suppose he gets busted; he's moved out. Now one of those guys who's working for him is going to move up to his job to fill his slot. It's going to become automatic.

"The fact that one guy's been busted, that he faces fifteen years in prison, has nothing to do with anything. It's a matter of slots; it's moving into somebody's slot. You can't do the hustle unless you know what it's about. You move in and you move up. So there is no deterrence. There's no one to deter. Everybody's looking to move to a higher slot, in the straight life and the hustling life. Everyone's striving to survive.

"An example-ten or fifteen years ago, when the Court started to hand out these long sentences to the older guys, all of a sudden young people were doing it. No one could figure out where they came from. It's very simple-they moved into slots. The same way the boss on the job in the company that you work for is the creator and perpetrator of jobs, is the same way that the Court was the creator of slots. The old guys didn't tell the young guys how to do it, but when the old guys started getting slapped down by the courts, then the courts were creating new slots for younger guys, and that's how criminality got younger. Deterrence's got nothing to do with the real world. In the real world it's all about filling slots."77

"You think you done something by putting me away," said Pete Arnold, "but more come out of the woodwork, man, like roaches."

On March 15, 1989, we suspended interviews at Lorton because twenty-five miles north, in a hotel conference room, many key players had gathered for the D.C. Bar Association Meeting, titled "D.C. Prisons

76. "[I]t is not at all certain if deterrence is a psychological theory based on threats, or a sociological theory based on social control, or perhaps both." P. BEAN, supra note 7, at 29. 77.

Is it not a delusion to substitute for the individual with his real motives, with multifarious social circumstances pressing upon him, the abstraction of "free will" .... [I]s there not a necessity for deeply reflecting upon an alteration of the system that breeds these crimes, instead of glorifying the hangman who executes a lot of criminals to make room only for the supply of new ones?

Karl Marx, Capital Punishment, N.Y. Daily Tribune, Feb. 18, 1853, at 3, col. 5, cited in Jeffrie A. Murphy, Marxism and Retribution, 2 PhIL. \& Pub. AfF. 217 (1973). Morris Cohen cites the argument that

the main cause [of crime] is a result of economic conditions; and since society is responsible for these economic conditions, society itself is responsible for the crime. On this view it is as profoundly foolish to devote our attention to the punishment of the criminal as to concentrate on the swatting of mosquitoes while we allow the breeding ground to continue.

Cohen, supra note 10 , at 1005 . 
in Crisis." In a panel discussion, Alvin Bronstein, founder of the ACLU's National Prison Project, insisted that although in the last decade alone Washington, D.C.'s prison population had quadrupled-to 11,000 - "none of this has ever had or ever will have any impact on the very serious crime problem we have in the district. We could lock up 22,000 tomorrow, or 33,000 tomorrow, and the crime rate in this city would stay statistically the same. We will have no impact by our incarceration policy."78

In effect supporting Reggie Brooks's slot theory, Bronstein claimed that studies show prison deters only non-alcoholic drunk drivers and economic white collar criminals. "They think about it; it's a thought process. Street criminals don't go through that thought process. Those people killing on crack are not stopping to think 'What if I get caught?' Most of them don't believe they're going to get caught, and they're right, they won't get caught. Most of them don't think about it. So there is no possibility of general deterrence for that crime."

Later, Professor Norman Carlson, former Director of Federal Prisons, challenged Bronstein: "You're not suggesting that if you turn loose 600,000 persons from the state and federal prisons at one fell swoop there would not be an increase in crime. There certainly [will be]."

"Obviously, I'm not suggesting that they be released," Bronstein replied, "although many of them could be released safely. I'm not suggesting that we abandon the concept of incarceration, because I don't know what to do with them. The few dangerous people that we have must be locked up. I don't want them on the streets. But I would suggest to you that if we release all 600,000 , which I am not advocating, we would not have a statistically significant effect on crime. We do incapacitate these people, but overall, of the terrible crime in this country, it's a minuscule amount that is deterred."

"Ninety percent of the people incarcerated have a prior conviction," protested Jay Stephens, U.S. Attorney for Washington, D.C. "Eighty percent have a prior felony conviction, and over half have two prior felony convictions. We're not talking about incarcerating individuals who are involved in committing minor crimes .... We're talking about people who have been convicted in a court of law of two prior felony convictions and now they're incarcerated again. And it does add some protection to the community to have those people off the street and in the prison."

"I was never denying that we . . . have a dangerous and serious crime problem," Bronstein replied. "I acknowledged it. It's terrible.

78. Bronstein cited statistics demonstrating that Washington, D.C. was "warehousing three times as many people per capita as New York City," and that while the prison population in Washington, D.C. had tripled in the forty-eight years from 1930 to 1978, in the last ten years alone that population had quadrupled, from 2530 to 11,100 . 
But I still say to you that the incarceration rate in this city is disproportionate to the rest of the country...."

"Is it disproportionate to crime in this city?" the federal prosecutor demanded.

"No. But it has no impact on crime."

"It's not disproportionate to the crime! That's all I ...."

"It will have nothing to do with the crime," Bronstein persisted. "That's the thing you have to understand. Incarceration policy has nothing to do with crime policy! You cannot solve the crime problems in this society or any other one with an incarceration policy, unless you lock up everyone."

Exercising a moderator's prerogative, Professor Eleanor Holmes Norton sought to end this exchange by locating common ground: "The incapacitation effect may be different from the deterrent effect. The incapacitation effect is obvious-for the time you're in prison, you cannot commit a crime."

\section{Incapacitation}

Originally prison's sole purpose was to hold prisoners until trial or punishment. Today, incarceration-taking criminals from the streets and confining them-remains prison's front line, and perhaps bottom line, justification. ${ }^{79}$ The experience inside may not be retributive, it may not rehabilitate the inmate, nor deter him or others, but at least that criminal is removed from society and to the prison, where he is disabled from committing further crimes.

Of course society insists that prison incapacitates. Television cameras traversing barbed wire fences and armed guards in the towers testify that "thou shalt not escape." Prisoner Pete Arnold graphically described the pressure on the administration to prevent escapes from this all-black D.C. prison located in the midst of an all-white Virginia suburb: "The only thing this institution is concerned with is that the motherfucking count clear. That every swinging dick in the count be here. It's only then that they concerned. Then they likely to feel the heat from upstairs. Not because John stabbed me and killed me. That's an expected occurrence. But not no rapist jumping the motherfucking fence, going through the countryside, kicking doors open, making some young girl sixteen years old suck his dick, giving him the car keys and opening the refrigerator, drinking a beer before he leaves. That's their motherfucking nightmare."

Although filled with "lifers" and other long-term felons, Lorton

79. "Incapacitation as a goal of punishment is in many ways the cleanest form of individual prevention. Its objective is to deny, or at least greatly reduce, the opportunity to commit future offenses." P. Low, J. Jefrries \& R. Bonnie, supra note 6, at 22. "If all else fails, the utilitarians fall back on the most easily defensible argument for the use of criminal punishment, which is that of incapacitation." G. NEwman, supra note 16, at 105. 
Central was designed and is classified as only a high-medium security prison. Over the years several prisoners have escaped. Recently, a trusted inmate working at the perimeter, apparently fearing transfer, kept walking. Another prisoner took advantage of a malfunctioning camera and Lorton's nonelectrified fence to cut his way out. Prisoners report that inmates who worked in the records office-a practice recently abandoned-were able to change 20-to-life sentences to 2-tolife, eliminating eighteen years of suffering incapacitation by erasing an "0."

Even though sentences have gotten much longer and inmates believe escape is not that difficult today, very few prisoners plan or attempt it: "In the old days you ask a guy what he's got. 'Eight-totwenty-four.' 'Man! That's a big number.' Today, it's forty-five-to-life, seventy-five-to-life. You got to do that front number. That's forty-five fucking years. And he don't care. He accepts it," Johnny explained. "We used to try to crack that fence, one way or another." Filing through the fence or filing a writ-it made little difference to the oldtimers. Today's younger inmates, however, rarely know who their lawyers are, and seem unconcerned about the status of their cases, content to live at Central.

Why? What keeps them inside? Less a fear of being shot while scaling the fence, than the punishment which follows an unsuccessful escape attempt: Transfer. Lorton, Virginia is easily accessible to Washington, D.C. As Reggie Brooks said, "They got three or four of their little buddies serving life sentences with them here, and they're in heaven." A transfer to Wala Wala, Leavenworth or another remote prison cuts off an inmate from his family, friends, his familiar environment. Punishing escape with transfer deters; ${ }^{80}$ it is also ironically retributive.

An inmate who does not escape, however, is not necessarily incapacitated. Incapacitation requires more than confinement. While incarcerated, an inmate must commit no crimes against society. ${ }^{81}$ Prisoners inside Central rarely assault visitors, teachers, counselors, or officers, ${ }^{82}$ mostly because they fear transfer. But prisoners often kill prisoners. Inside Lorton Central serious stabbings and murder attempts are an

80. See text preceding note 74 supra.

81.

[T] he empirical basis for incapacitation is clear beyond argument. So long as we keep a man in prison he will have no opportunity at all to commit certain kinds of crimes-burglary, obtaining property by false pretenses .... And his opportunities to commit certain other kinds-such as assault or murder-are greatly diminished by confinement.

H. PACKER, supra note 10, at 48. When he wrote this, Herbert Packer obviously did not have Lorton Central in mind.

82. During the course of this study, the rape of a teacher and the stabbing of an officer apparently attempting to enforce telephone restrictions caused major uproars. 
everyday event. 83 Every inmate who wants a weapon has one. "There's no way to stop them," said Captain Townshend. "They can make them out of anything. If I was an inmate, I'd have one for my own security."

Prisoners disagree over which is more dangerous, the joint or the streets. Inside Lorton Central there are very few guns, whereas the streets of Washington, D.C. have become a battlefield. On the other hand, in the closed environment inside Central, there is nowhere to run, nowhere to hide. ${ }^{84}$ On the street when a guy cuts in line or "rips you off," you can ignore it. You will probably never see him again. But inside Lorton Central, with everyone watching on the side-lines, you must counter such disrespect, or others will take advantage of you. "In the street when you're doing something wrong you're seldom doing it in your neighborhood," said Johnny. "Lorton is the neighborhood. Each time you take a pair of tennis shoes, a radio, a sweatsuit, you risk your life." 85

"You can get killed for asking a dude for his physical body. You can get killed for taking his shoes. You can get killed for trying to take his food," said inmate Danny Bethel. "You can get killed for messing with his people. You can get killed for reading a man's mail. You can get killed for taking a guy's pictures. But you got to recognize that you can get killed for nothing. Now if I could wake up at three o'clock in the morning with a hole in my neck, paralyzed from head to foot, then it can happen to anybody."

Many citizens might react with indifference or even pleasure at these conditions: "Let them kill each other." 86 And some officers, constantly confronting a generation of violent vicious kids out on the compound, may be satisfied merely to prevent their escape. "What's the purpose

83. "[C]onfinement does not incapacitate so much as shift victimization from persons in the community to persons in the institution." A. Von Hirsch, supra note 10, at 112 n.*.

84. "Compounding the loss of liberty is enforced intimacy with uncongenial strangers. Inmates who are forcibly kept together may have or can develop strong antagonisms based on race, social class, ideology, gang conflict, or personal animosity: close living aggravates such tensions." Id. at 110.

85. A frightened inmate, expecting attack, may try to protect himself by "dropping a note"-anonymously warning the administration that he will be killed-forcing them to send him behind the wall, to protective custody in Maximum. Sometimes he may drop a note, warning of danger to his would-be attacker, who will then be mistakenly removed for his own "protective custody." The administration, once notified, heeds these warnings, both because they feel morally compelled to do so and because they fear lawsuits after a stabbing.

86. Ignoring inmate victimization reminded Professor Zimring of the stranger who, stuck with a stubborn horse, was advised by a local resident to activate the animal by smashing his testicles between two bricks. "[T]he stranger asked, 'Doesn't that hurt?' [H]is mentor responded, 'Not if you don't get your thumbs in the way.' " F. ZIMrING, supra note 48, at 2425. Immediately preceding this charming anecdote, Zimring observed:

The offender is a citizen, and the community's decision making process exists to protect his welfare as well as that of others. ... [i]f the offender's suffering is not taken into account as a cost, the usual result of comparing the cost of extra offender suffering and alternative crime reduction methods will be to opt for the extra suffering.

Id. at 24 . 
of Lorton?" asked Sergeant Shipley rhetorically. "To keep them inside the fence and outside society." But inside the fence "is our society," said Pete Arnold, "the society we are making here." And if incapacitation is to be fulfilled, this society, too, must be kept safe from its predators.

"If you ask me what my greatest objective in the institution is," said William Hedrick, former Acting Administrator at Lorton Central, now Assistant Administrator at Maximum, "it's to keep people from getting hurt, both the inmate and the staff."

"What are you here for?" Sergeant Cody was asked.

"To help keep and safeguard."

"It sounds like you're reciting a written regulation."

"That's exactly what it is," Cody replied.

"But what are you really here for?"

"That is what I am here for. ... [T]o keep him safeguarded by the process of law."

In theory, prison incapacitates by protecting society from the criminal. Lorton Central, however, sometimes protects the prisoner from his society. "There are a lot of people in here whose lives are saved by being here," Itchy Brooks observed, "because if they were out on the street they would be killed by people they'd done things to." This, then, is Lorton-style incapacitation: the protection of the punished. ${ }^{87}$ And once the concept of incapacitation is extended inside to include relations among prisoners, its basic definition-that the inmate in prison commits no crimes-is more obviously violated.

Inside Central, street hustlers have become prison hustlers. "We have perimeters that we can't cross, but we have a lot of ground that we can cover," Pete Arnold chuckled. "I'm sure that society don't know that the same guy that sold dope on the street is selling it right here," Johnny explained. "The same guy that stuck up on the street is doing it right here. The things they did which got them into the joint is what they'll do while they're in the joint, is what they'll do when they get out." Inmates revealed a variety of prison crimes: selling marijuana, PCP and other narcotics; selling stolen food-fresh vegetables, sandwiches, ice smuggled from the kitchen; selling other people's property, stolen from lockers; pulling shots, i.e., removing or altering a record of disciplinary proceedings. "A few guys don't do anything-don't hustle, don't work, don't go to school, just stand around or lay around," said Johnny. "But the majority of guys are out doing something: selling

87. The "Unstated Organizational Goal," identified by Cressey in the title of his article is "protection of inmates from society." Cressey, Achievement of an Unstated Original Goal, supra note 19, at 43 . As noted earlier, however, Cressey's point is that inmates were protected from "individuals who wanted to 'study' them, 'reform' them or use them in some way." Id. at 44. Also, "inmates were efficiently protected from dishonesty and physical violence on the part of staff members and other inmates." Id. at 44. 
vitamins, selling antibiotics, selling just about everything and anything that's not tied down."

Most crime on the streets and in prison is related in some way to narcotics. And, as in the street, inside Central people fail to deliver. Money is "messed up." Arguments break out. Prisoners retaliate.

Inmates often insist that the administration of the D.C. Department of Corrections permits a flow of drugs into the prison to tranquilize them. They also believe that the white power elite of the United States has encouraged the flow of narcotics into the black communities to pacify them. While both conspiracies are probably much exaggerated, ${ }^{88}$ drugs are everywhere inside Lorton Central. Former D.C.D.C. Director Hallem Williams has publicly cited results of urine tests as proof that less than ten percent of the prison population is using narcotics. However, inmates and officers on the compound scoff at this figure, revealing many ways to distort urine tests, and estimating-with remarkable agreement-that approximately seventy-five percent of the prison population is on drugs.

Drugs are smuggled into the prison on delivery trucks, by officers, and by visitors. Prisoners, called "slam dunkers," specialize in storing balloons full of narcotics deep enough in their anal cavities to elude the mandatory visual strip search conducted when they exit the visiting hall. While most every kind of drug available on the street is also available inside Central, the drug of choice is the highly addictive love boat. "Boat" produces hallucinations and flash-backs, making an inmate feel at once paranoid and omnipotent. Everyone is out to get him and no one can stop him. "PCP is really a killer," said Captain Townshend. "Someone under its influence is totally unpredictable. An inmate will fight five or six others singlehandedly. He will attack guards. He will do anything under PCP."

Many stills operate inside Central, producing wine from canned fruit smuggled from the kitchen. "Wine is a big commodity here. There's always two or three bars working," said Johnny. "Some guys make it; some guys sell it. When the wine is really good it draws a lot of people. And certain officers on the walk, nine times out of ten, know who's selling it. 'Hey man when you're finished, I want my cut.' A lot of officers hustle for inmates, hustle off the inmates-catching them dirty with money, narcotics, or sandwiches, and taking it. Of course a guy will say 'It ain't mine, it's yours, you got it!' That's the smart thing to do. Eight out of ten officers would accept that." Not all the officers hustle. But the inmates believe that most of those show up only to put in their hours, collect their paychecks, and leave.

"No one is concerned anymore about the individual prisoner," com-

88. See Jack E. White, Genocide Mumbo Jumbo, Time, Jan. 22, 1990, at 20 (describing and dismissing the theory that the white power elite has encouraged the flow of drugs to pacify or kill blacks). 
plained Alvin Hines. "Their top priority now is that the count clears, that no one escape. They don't care about anything else. They don't care if he gets an education, they don't care if he saves money; they don't care if he sends money to his kids. Prison-years ago-if a man had kids, the officers would get on him: 'I want you to work and send some money back to the street. You show me that and we'll give you parole.' But now it's not that kind of attitude. They don't care what you do, as long as you don't escape. It's a holding situation now. 'Court says we got to hold you. We hold. Court says you got ten-tothirty, we going to hold you ten years. We don't care what else happens. Then we can let you go out in ten years." "

A laissez-faire attitude, however, suits many of the younger prisoners just fine. As one smart aleck told Sergeant Shipley, "Judge said I got ten-to-thirty years. He didn't say I got to get out of bed to serve it." But it angers older inmates like Charlie Williams who feel abandoned by an uncaring system: "If you read the commitment paper, all it says is 'hold the body of Charles Williams.' That's all they care about, to hold my body."

The ranking administrators agree with the older inmates that officers must be more than mere guards or "turnkeys," that prison must do more than merely incapacitate. "Do we as correctional professionals accept that we can't do anything with these wards of the court?" asked Administrator Roach. "That we just warehouse men and women, just locked up until the time that the judicial authorities say 'Okay, go back out there'?"

Thus, from the outside, the prisoners of Lorton Central seem to be incapacitated. Rarely do they cross the perimeter or even test it. Inside the prison, however, crime-the sale and possession of narcotics, theft, assault, and murder-is rampant. In the words of inmate Pete Arnold, "It's a fucking zoo."

\section{Specific Deterrence}

In theory, then, having committed no crimes while he is incarcerated, the prisoner, once released, carries with him painful memories of his prison experience, which continue to haunt him, pressuring him to avoid criminality and live the straight life. ${ }^{89}$ In theory.

If, as Hobbes defined it, memory is "decaying sense," then painful prison memories have a very short half-life: "In twenty-five days you've forgotten the experience of twenty-five years," said Itchy Brooks. "All the lessons you learned." 90 Pressed in the streets, memories of Lorton

89. Unlike general deterrence, and in common with retribution, incapacitation, and rehabilitation, specific deterrence concerns the actual effect of punishment on a particular criminal. "[I]t seems natural to expect that the experience of punishment would tend to strengthen fear. The abstract threat of the law has come to life, and the offender visualizes the consequences more clearly than he did before." J. ANDENAEs, supra note 62, at 176.

90. "[S]hortly after release the ex-inmate forgets a great deal of what life was like on the 
quickly fade. The immediate dangers, the uncertainty, and the insecurity can seem worse than life in Central with its "three hots and a cot."91

"I know what the penitentiary is about. I've dealt with it," said Leo Simms. "Inside, I guess I know I can deal with it. If you check my records it seems I am able to deal with the institution better than I do with the street. You can institutionalize a person. I know what to expect here. I can be inside any institution for a week, and I can close my eyes and know the routine from hour to hour. ${ }^{92}$ It doesn't offer me any challenges. It's a lesser threat than I would have in the street. The decisions you have to make in the free world you don't have to make here. I know it's sad to say, a guy my age, but you can get in the habit of having people make decisions for you. You have many guys in this institution that cry every day about wanting to get out, but their actions dictate different, because in their heart they can't really want to go, because they don't know how to make it out there. We have a closeness that you don't have in the street. . . . When you're sick here, everyone want to know how you are. You might have twenty guys .... It's sad but it offers something to individuals that you don't get in the street."

"So jail for you is not a deterrent at all. It's only a part of the type of life that you lead?" Johnny asked Leo.

"It has been an important part. It's not only me. You got a million of us that it has came to be our refuge. When things get rough. And it should be the opposite way around, but in our heart this is our refuge. You come, and you hope each time that you get enough of whatever you need to deal with the reality and responsibilities of the free world. But for me to say that what I remember scares me out of my shoes-I'd be lying." 93

Dr. Reynolds, Chief Psychiatrist at Maximum, summed it up bleakly: "Before the first time, they don't think about it; after the first time they get used to it." 94 "When I was on the street," said Robert Moffitt, "I used to say to myself 'I wish I could go to jail for about six months or a

inside and once again begins to take for granted the privileges around which life in the institution was organized." E. GofFMAN, supra note 19 , at 72 .

91. Three hot meals a day and a bed in which to sleep can seem most attractive to a homeless ex-convict.

92. James Hayes expressed unhappiness that prison rules inside Lorton Central were not uniformly enforced: "I've become so adaptive to jailing that I can find comfortability in the most uncomfortable spot. When they change it up, that shakes my comfortability. I sort of resent it."

93. Prison as a "refuge" is an old theme, well explored in the literature. In 1917, Enrico Ferri wrote of "born-criminals" on whom a penalty has no effect "because they consider prison as a refuge where food is assured them even in winter without need of much labor ..." Enrico Ferri, Criminal Sociology 144 (1967), quoted in S. Sylvester, supra note 61, at 119. For descriptions of prison as a refuge, drawn from literary classics and prison accounts, see Martha Grace Duncan, "Cradled on the Sea": Positive Images of Prison and Theories of Punishment, 76 Calif. L. Rev. 1201 (1988).

94. "In penological literature it is often asserted that the offender's fear of imprisonment is much reduced once he has become acquainted with it, but there does not seem to be 
year maybe, just to get myself together.' Jail is about the only place a man can get himself cleaned up." Specific deterrence fails miserably when prison becomes a refuge.

For some inmates, Central is not so much a refuge, but an acceptable, if unpleasant, necessity. "I operate on the premise of my being a hustler and this [is] part of it, part of the game that comes with it. It's a deterrent as far as educational things," said Rodney Hunt. "I won't make the same mistakes in the future. I'll do it another way."

"How many people that's doing the time that you're doing for the crime that you did would say that 'I'm not going to do that no more'?" Johnny asked Leo Simms.

"I've talked to many guys here in Lorton, and they want to talk about a new way of doing it," said Leo. "But as far as not doing it, I don't think I've talked to one that has in his mind not to do that, period. Just another way."

"Some of my partners I met in the joint," said Johnny, "sit down and talked about it even before they came home, and say "Hey, stickup alright, and it's been good to me, but we got to change up because they giving out too much time. If I come back for stickup, then I'm going to get all of it this time, so I have to carry my hustle another way.' "

After serving ten-and-a-half years for armed robbery and assault with intent to kill, inmate Wade Briggs "knew the old game wasn't going to work. If I got busted for sticking up somewhere else, they'd probably hit me with 'Ten years didn't do you no do good. We'll give you forty-five-to-life." " So Briggs decided "to try something new," switching to drug dealing, figuring that "if I did get busted, it wouldn't be so much of a big time thing." He could then plead to the judge, "I learned my lesson."

"So in other words, it's more or less profiting from your mistakes," Johnny concluded.

"You come here for stealing a car, you leave here knowing how to crack a safe," Itchy said. "This is a crime factory." 95

any systematic research which could prove or disprove such assertions." J. ANDENAEs, sufra note 62 , at 177 . Immediately preceding this, Andenaes observed:

We cannot, however, take for granted that the experience of punishment always tends to strengthen the offender's fear of the law. It may work the other way. It is conceivable that he has had exaggerated ideas of the consequences of being caught and now draws the conclusion that it was not as bad as he had imagined. More important, probably, is the fact that if a person has been convicted of a somewhat more serious crime, and especially if he was sentenced to imprisonment, he will have Id. less to fear from a new conviction, since his reputation is already tarnished.

95. "The idea that punishments may actually cause more crime than they prevent is reflected in the claims, found in much of the recent criminological literature, that prisons breed crime by exposing otherwise unlikely recidivists to criminal role models and underworld contacts." P. Low, J. JefrRIEs \& R. BonNiE, supra note 6, at 27. "The prisoner may leave prison as a worse man than when he entered, more deeply entrenched in a criminal culture, more hostile to society and its values." J. ANDENAES, supra note 62, at 179. 
Prison experience, then, fails as a specific deterrent for the ex-convict on the streets who remembers it as a refuge, or accepts it as an inevitable part of hustling life. And the experience fails to specifically deter those it makes more cautious or those ex-convicts it opens up to new criminal opportunities. Most perversely, out on the street, specific deterrence fails when a convict's obvious indifference to repeating a long bit may make him an even more effective hustler. His threats are credible-"I've done hard time; I can do it again."

He may come out more vicious than he went in. "Prison is not a healthy place to be," said Itchy. "The people in the community say, 'Well, it's not intended to be. We don't want it to be.' Fine, so when a guy come to the gate to blow your fucking head off, then that's what you apparently wanted. You should have expected it. Because that's exactly what the fuck you're doing. When you put a man in prison and you say 'life,' then make that life. Or you're asking for it."

"What do you do with a Doberman Pinscher when you want him to be mean? You make him hungry and keep him chained up, restrained from everything. When you let him loose he goes wild. It's no different with us," Itchy said. "You in such a state of deprivation when you leave here, you want everything and you want it now. You don't want to wait. You've been waiting too long. You've been waiting on too many lines. You done took shit from too many people. You ain't taking any more shit.

"So when you go on the street with that attitude you're dangerous. And that's that. This is a monster. But where did that monster come from? You were a small monster when you came but you're a giant one when you go out of here."

Why, then, doesn't every ex-prisoner return to prison? Why is any Lorton Central ex-con ever deterred? Two factors, often noted in the literature, were reflected inside the prison. "I would never come back to this place," insisted Danny Bethel. "I've overstayed my welcome. I'm too old for it and I can't take it no more. There comes a time in all of us where it's time to quit. There's no force, there's no power that can make me commit a crime. My time's over; I'm just not coming back." For many, like Bethel, Johnny, and Leo, the aging process itself makes specific deterrence work. ${ }^{96}$

"I'm just tired of coming back to jail," said Leo. "My age-that's what deter me, but if I weren't my age, if I were a younger man, I would try it again out of spite because I don't like what they gave me, for what they gave me it for. I'd go at them again. But since my age, I ain't messing with it no more. If you want to say that's a deterrent, that's OK. I guess some could say that four-to-twelve they gave Mr. Leo (for

96. "Of all the causes which influence the development of the propensity to crime, or which diminish that propensity, age is unquestionably the most energetic." A.J. QUETELET, Treatise on MAN 92 (1842 \& photo. reprint 1968). 
the sale of heroin with a street value of twenty-five dollars) was enough. Yes, at this age, yes."

What is it about the aging process that specifically deters? Classical deterrence theory presupposes that individuals weigh costs and benefits. A specifically deterred ex-convict has reevaluated prison in such a way that its costs outweigh the benefits of crime. Why only after many years and several "bits"?

Family is the great motivator. "It would be a lot different for me if I had a second chance," mused Earl Grier. "What it boils down to on this charge and me doing this time, is that it really wasn't worth it compared to what I have lost since I been here. I had a nice home; all my family was together. Now all my children are spread all over: Southeast, Northeast, Maryland, New York."

"Thinking about your family and their dependence on you is more of an immediate deterrent than the prison itself," explained Johnny, determined never to return. Not being with his grandmother before she died, not being able to protect and influence his children, not being able to guide his grandchildren into educated drug-free lives, eats at him.

"The guy in Lorton whose mind is here is the one who's lost," said Itchy. "There's some guys here whose bodies is here and their minds are in the street with their families, what they're going to do when they get out. Those are the ones that's going to be saved. A person who strives to do positive things is a person who has reason for doing it. If you have a stake in what's going on outside, if you're conscious of how much you're costing other people by being here, then you'll do what you need to do to get out and stay out."

Henry Daniel summed it up: "The only people who can be deterred, really, are people whose responsibilities are greater than their desires."

What do we say of such a convict whose prison experience has changed his cost-benefit calculus? "Perhaps, leaving the prison he is not an honest man, but he has contracted honest habits," wrote Tocqueville and Beaumont in 1830 upon their visit to the United States to inspect its newly constructed penitentiaries, "and if he is not more virtuous he has become at least more judicious." 97 The convict now regrets the waste of his years and the toll on his family, but as he returns to society, he remains willing to do whatever he thinks he can get away with, as long as it is worth the risk. His prison experience has given him a more realistic appreciation of state power. On the streets, the criminal lifestyle no longer seems worth it, but only because punishment

97. Gustave de Beaumont \& Alexis de Tocqueville, On the Penitentiaky System in the United States and Its Application in France 90 (H. Lantz ed. 1964) (1833), ciled in D. ROTHMAN, supra note 15 , at 103 . 
now is too expensive. Has this convict been "rehabilitated," or merely specifically deterred?

"Once you've made up your mind," said Leo Simms "you can be in a hole in the wall, eating bread and water, and you make up your mind-'when I do get out of this place, there is nothing that will bring me back.'"

"That's deterrence; it's not rehabilitation," Johnny observed, by this time schooled in the traditional distinctions. "I would look at rehabilitation as a guy who say 'OK I will go to school and get my G.E.D. [high school equivalency degree] and I'm going to get a trade so I can get a job, and when I go back to society I'll be an active member of society.' That's rehabilitation."

"It doesn't matter what particular condition he's in," Leo disagreed. "It's a matter of saying 'this is it for me!' There's not a whole lot of problem with living in the street, once you make up your mind. You can buckle down and say 'Hey, I want my freedom. That's more important than anything in the world to me. I can go and get it with what I got. I want my freedom, with what I have.' And go from there. So if you want to call that deterrence, or rehabilitation ...."

"It don't matter what title you put on it," said Johnny, closing the discussion. ${ }^{98}$

\section{E. Rehabilitation: "An Eye Patch For An Eye"99}

Traditionally, in the literature, rehabilitation and specific deterrence are presented as complementary, if not indistinguishable. Specific deterrence and rehabilitation do overlap. Perhaps specific deterrence is the threat of repeating a bad time inside, whereas rehabilitation is the promise of a better time outside. If rehabilitation is successful, a criminal learns his lesson-to avoid crime-when his newly acquired skills and values attract him to the straight life; if specific deterrence is successful, haunting memories of Lorton Central repulse him from a return to hustling and prison. However, these philosophies may actually conflict inside the prison, where an environment conducive to rehabilitation-one that provides educational programs, counseling by caring inmates and staff, and a time and place to take a needed breather from the streets-is remembered fondly by ex-prisoners now struggling to get jobs, support families, and meet the demands of outside life.

Rehabilitation-or reformation-essentially consists of the acquisition of attitudes, values, habits and skills by which an "enlightened" criminal comes to value himself as a member of a society in which he can function productively and lawfully. This glossy definition is appeal-

98. "The concept of special deterrence is difficult to separate from rehabilitation." $P$. Low, J. JEFFries \& R. BonNiE, supra note 6 , at 21.

99. This phrase appeared on an anonymously graded New York Law School Criminal Law final exam. 
ing, but reveals little of the rehabilitative process with its pitfalls and problems. What is rehabilitation really? Why does it so often fail? And what does it take to succeed? We sought answers from inmates and staff. They directed us to look outside at society and the streets of D.C.; to focus inside Lorton on the programs and personnel and the relations among fellow inmates; and ultimately to look inside each inmate's psyche, and his personal commitment to change.

\section{Back out, back in.}

"This place is not working," observed Sergeant Edmonds, stating the obvious. "But you cannot change it inside and not change the outside. Even if a guy has good intentions, and says, 'I am going to get out and go straight, be a good father, be a good provider.' He goes back out into the system we are in. He is a convicted criminal. That's one strike against him. He's black or Hispanic, so he's got two strikes against him. When he gets back out there, who's going to hire him? The average business really does not want a convict employee. What did he do? Can he be trusted? How will other employees feel with him around? So if he gets a job, it's going to be a low-level, low-paying job. But his aspirations are as high as anybody else's out there. He wants the American dream too. A lot of them get into crime because they want the American dream. The reasons that brought him here never changed. The have-nots want to have."

"I talk to guys come fresh back. 'It's tough out there Sarge.' I talk to guys over at Minimum. These guys have less than a year and are waiting to go on work release. They are scared shit, especially guys that have been locked up for awhile: The whole city has changed. Sure, the old neighborhood is going to be there. But there are going to be a whole new set of new faces in that old neighborhood. It's going to be rare to walk down the streets and see five people that you know. They play the bravado role, because that's the he-man thing. You are supposed to do that. 'Guy's got to carry it, a man got to do what a man got to do.' That's Lorton; that's the hill; that's being tough. And that's all bullshit. ${ }^{100}$

"I have not seen a remorseful person come back to this place. I mean people who have done long numbers go out there and stay a heartbeat, and be back. And they are not 'Oh, God, I'm back. Jeez, what am I going to do?' They come back. They fit back in like a piece of a puzzle, like they never left."

Itchy described the psychological corrosion of a prisoner, released

100.

[T] hose about to be released very often become anxious at the thought, and, as suggested, some mess up or re-enlist to avoid the issue. The inmate's anxiety about release often seems to take the form of a question put to himself and his friends: "Can I make it on the outside?"

E. GoffMan, supra note 19 , at 70 . 
after a long bit, initially determined to stay out: "You're going in the street," said Itchy, "with the fifty dollars they give you and you have a whole new situation where you haven't been making no decisions for four or five years and now you have to make them all. You haven't had to do nothing but make ugly faces and look tough in here to get by. Now looking tough don't get you nothing. So you're out there and all your good intentions, all that shit don't amount to a hill of beans, because it's back to real life, it's back to the survival struggle. . . Y You're out there and everything is falling apart; everybody's got a family except you-yours fell apart a long time ago while you were in here.

"And your buddies come by and say 'let's take a drink.' 'Man, no, I got some things I'm trying to do' and that lasts for awhile. Because you see yourself accomplishing something, you see yourself trying to do something. But then after a few months go by and you're still in the same situation you was, you see yourself making no progress, your prospects are the same as the day you came out. Nobody's seriously offering you anything. You got some people telling you 'well if you go down and sit outside the union somebody will come by and offer you a day's work.' What is a day's work going to do toward paying the rent? You don't got enough money to more than get you a drink, or buy you some dope and put yourself out of your misery. The next thing you know, you find that all this stuff about Lorton is fuzzy in your mind. 'Damn, I sure did rough in Lorton. But at least somebody had their foot on my neck and kept me from doing better. Now, here, nobody got their foot on my neck and I still can't do better.' Then you start backsliding. You start going around with your buddies and doing things you hadn't planned on doing."

"When you leave here," said Johnny, "You don't have no money. The people you know in the street are hustling. A guy may offer you some drugs, or somebody going to say 'Here's five or six hundred dollars. Go downtown and get yourself a couple of outfits.' And then the same guy, a couple of days later, going to say 'Hey, what you doing?' And you say 'I ain't doing nothing yet. I'm still looking around.' In the course of a few weeks you're getting back into the swing of things. And then this guy come back again in the Mercedes Benz or the BMW and that six is gone. And he say 'Hey, you ready to go to work now?' And you say, 'Of course.'"

"And the sophisticated surveillance they [the police] got," Charles McCulloch added. "They got a task force of people who just watch career criminals: 'Joe Blow is coming home. We busted him five times in the last ten years for selling narcotics.' Agent takes Joe Blow's folder, sits out in front of his house, follows him for the first month. knows every move he makes."

Leo Simms told of a fellow inmate, newly paroled after a long bit and determined to go straight, out on the street with no money. An old 
hustling buddy approached the parolee and embraced him, insisting he sit tight for a few minutes while he called in some money. Sitting on a bench, a few minutes later, moments after he'd accepted the money gift, the parolee was arrested by the narcotics squad-who had been watching the whole scene from a rooftop. The money his buddy had given him had been marked; he was charged with drug conspiracy and returned to Central for ten more years. Sometimes the "system" doesn't even give the ex-convict a chance.

"You talk about recidivism," said Charles McCulloch. "Let's stop it by giving this man an alternative to getting help from his buddy. Give him something he can feel man. Give him something he can touch. Make it real. Make it possible for him."

Many older convicts desperately want to go straight. But when asked by Johnny about a "game plan" to stay out in the streets once released, most were resigned to their bleak prospects.

"I can't say I'm not going to never come back," conceded Robert Moffitt. "All I can say is I'm going to try my hardest not to never come back. Because they can get you for something you didn't do once you got a record. I'm going to be real discrete about what I do out there."

"That's a hard question," concurred Charles McCulloch, who has struggled the last thirteen years to stay off drugs "one day at a time." "In all honesty that's a hard question."

"Is it hard because you know eventually you are going to hustle?" Johnny asked. "Is it hard because you are a hustler and do not intend to stop hustling? Is it hard because you feel you don't have no choice but hustle?"

"I don't think the options that face you are that great. I'm not a person who goes out and in ninety days I'm back; I usually stay in the street three years. But at this point the options I have to stay out and make a living are very low. I'll get a job but I know that my wants and needs will always be there, and I'll feel, 'damn, you could be doing a little better if you do what you've been doing your whole life. ...' But as I say, I'm going to give it a good shot.

"Last time I was out there, my friend and I bought one of these big moving vans at auction. We were moving people and getting three or four jobs a week-some weeks we would have but one. But even those weeks, for two guys breaking up eighteen hundred dollars-that's a pretty good week. And that's still available to me, and I'd like to pursue that. But these people [the parole officers] won't let a man go to that type of job. You have to go to a job where they're going to book you in at eight-thirty in the morning and book you loose at three or four o'clock. That's the only kind of job they'll take."

"So you do see yourself, two, three, five years down the line that it's possible you will throw bricks and that you will be back," Johnny pressed. 
"I see myself as a possible . . . that that is in the horizon. I can't sit here and truthfully say 'no.' I can't do that. It's a very good possibility with the options-and I would make that the focal point of what I'm saying-with the options that you have, it's a possibility."

"You say you made a choice with your life. Was it a good choice or was it a bad choice?"

"It was a bad choice," said McCulloch, remorseful, but without self pity. "Right now my life is-I'm 43 years old. I feel like I'm in the fourth quarter of a football game and about three touchdowns behind. And I'm just hoping I can be within striking distance before the two minute warning. I'm just hoping I can close the gap a little in the next ten years, because after that, if I'm not close, I'll never be close."

Although the younger prisoners may tend to be more optimistic, their optimism is unwarranted in the view of the old-timers. "They got all these good ideas about what they going to do," said Itchy, "but it's all about performing miracles when you don't got the means to do it and no opportunities."

Some ex-convicts start out not only without opportunities, but also without a home. A convict must give the parole board his intended address. But often when he tries to go 'home,' he is confronted by a "dude who say 'I told the parole officer you lived here when you get out, but me and my honey stay here. I'm not going to work every day leaving you here with my woman, so you better find somewhere else to stay.' And he don't have a dollar-forty-nine in his pocket which means he's got to find some way to yoke somebody, some way to commit another crime."

Some prisoners, however, nearing the end of their term can look forward to returning to society with a home, a family, a job. Sergeant Edmonds portrayed the pressure on them: "Say you are here doing twenty-to-life. You did nineteen years six months. In that length of time you spent ten years just playing basketball, doing drugs and watching TV. No work ethic going for you because you never had to get up and do anything. Maybe you thinking now 'Jeez, I am getting close now. I better program my damn self.' Inmates be thinking that. 'I need to get into D.A.P. [Drug Addiction Program]. I need to get my G.E.D. I am building my little portfolio so that at my first shot before the parole board, they are going to let me out of here.' He's maximizing everything that this system has to offer to get out of here, but that means nothing. He is not rehabbing. It's just a game to get out. He does it all. The parole board say, 'Gee, this guy haven't had any shots [infractions] in the last nine years. He has completed all the programs that have been offered to him. He has been a model inmate, have not given nobody any trouble. What do you think? We ought to take a chance on this man. I think he is going to be okay.'

"Once he goes through the halfway house, does his six months, he 
is back out there. The structured life that was here, all those little supports, all those bricklets that we built up here, we have now in the process of putting him back into society removed piece by piece, until all of a sudden, he is now standing on the concrete on North Capitol Street, a free man, free to do what he wants to do with himself. Somewhere up in here, he misses those supports. Even though he hated the hell out of them, supposedly, when he was here. He still misses those supports, all the friends he had if he did that kind of time, are here in Lorton. They are not out there. They are here.

"The same people that came to visit him, the same lady, children came to visit him, now have to alter their life to fit him in. Before, they didn't have to do that. They just had Tuesdays, Thursdays, Saturdays and Sundays to visit in two hour blocks and back to whatever they were doing. Now he is there full-time. They have to integrate him into their being. Slap! 'I am back.' He wants to carry the same authoritative manner that he had when they came for those couple of hours visit. In charge. But they have lived independent of him, with the exception of the visits. Resentment builds. He is now a liability instead of an asset. Because he's not making the kind of money that is going to help motivate and lift them. What little that they now have, have to be shared with someone else. The food bill goes up. The use of the automobile is shared. All of the things that they had, now have to be shared with this guy. Even though they love him, this is a sharing thing now.

"He notices that the irritation factor is setting in, arguments ensue, words are exchanged. Now, it is crystal clear to him that something is wrong here. By now, the woman is saying 'Jesus, man, you're a drain on the family, you got to bring some money in here, we ain't going to live like this.'

“And it gets back to 'What do I know how to do?' Back on the Avenue. You are talking to your friends. You have resisted them. Maybe for six or seven months. You have resisted the temptation to put the package in your hand, or do a deal to make some money. A lot of the guys who have gotten out, the guys they see on the streets, those same role models are still out there living the high life, wads of money.

"One day you are coming up out of McDonald's, dirty and greasy, going home into the shit, arguments, and all that because you are not providing. You're choking, you are stifling them to death. And he says 'Give me the package; fuck McDonald's.' He knows from that point he's on his way home. This is his home, Lorton. The rhetoric is the rhetoric. This is home."

\section{Rehabilitation inside the joint.}

The prison administration can do little to support an inmate, once released to the brutal, indifferent world. Immediately prior to final release, spending a few months inside a halfway house may provide the 
ex-convict a place to sleep at night, psychological counseling, an opportunity to reconnect with family, hunt for a job, buy some clothes, save some money, and find an apartment. The D.C.D.C. is committed to improving the transitional setting. But for rehabilitation to succeed in the streets, it must occur before the halfway house, inside the prison.

During the first decades of the nineteenth century, wardens and criminologists in the United States, confident that a structured environment could reconstitute criminals into law-abiding citizens, proudly invited the world to witness their experiment with rehabilitation inside newly constructed penitentiaries. Within a few decades, most observers considered the experiment a failure. ${ }^{101}$ But during the last quarter of the nineteenth century and for the next hundred years, as retribution declined, rehabilitation again became a governing philosophy.

Based primarily on a rehabilitation model, judges-moved by their particular idiosyncratic emphases-set widely varying indeterminate terms for similar crimes. A parole board determined when each prisoner was rehabilitated, i.e., cured or treated and therefore now ready to reenter the community. Each prisoner was supposed to serve a sentence which in turn served his individual needs and his potential for rehabilitation.

But by the 1980s Congress and many states which had adopted rehabilitative models had long since concluded that their systems were total failures. Mandatory rehabilitation programs did not reduce recidivism. Inmates went through the motions and parole boards were fooled. Rehabilitation was unpredictable and undetectable. It could be faked but it could not be forced.

The inmates inside Central overwhelmingly agree: "I might go out there, stay clean for a long time, keep the parole board and police faked out like I'm going to be a goody-goody guy," a prisoner admitted. "But I know me. I'm going to hustle eventually. I'm going to sell something where I can get a fast piece of money. That nine-to-five will be alright, but that fast lane will be just a little bit better, if you just stay away from the police and the jails."

"Do most of the guys feel like you feel?" Johnny asked. "Feel like 'Hey, I'm going to go out, lay low for six months to a year or something and I'm going to get a job and make a good impression on my parole officer. And I'm going to keep the heat off me from the police officers, but eventually I'm going to start hustling again.' "

"A few of them do think like that, and some just go out there and hustle that first week. Some stay out a year or two. A few of my buddies have been out there two or three years. And they just started hustling. They doing pretty good. They ain't been cracked by police. Ain't been no trouble. Ain't nobody back in jail for nothing. Nothing,

101. See D. Rothman, supra note 15 , at xviii-xix. 
nothing at all. They getting away with their hustle but they're working too."

"So fakeout, like you say, really works."

"Yeah, it works."

The consensus inside Central seems to be that judges cannot predict, parole boards cannot detect, and prisons cannot force true rehabilitation. "A hell of a lot of guys only do things to please their parole officer," said Johnny. "The schools are so crowded but the people are there just to get their good time so they can get back out to the street," said Pete Arnold. "They can't force it upon you," insisted Rodney Hunt. "They can show you right from wrong, and suggest things, but the only way a person can change is if he want to change himself."

"It's on you," said Johnny. "If you make up your mind. But if you rely on the system, it will never happen. I don't care what program you're in; ain't none of that shit going to work until you want to do it."

When Congress finally overhauled the federal sentencing structure, abolishing parole and delegating to a sentencing commission the task of specifying fixed sentences for all federal crimes, it adopted a different philosophy of punishment. Although voluntary rehabilitation would continue as a goal ${ }^{102}$ inside the prisons, rehabilitation would no longer be any basis for or justification of imprisonment. ${ }^{103}$ Instead, Congress substituted a "just deserts" punishment model, which would include deterrence and incapacitation. The Legislature neither set priorities among the remaining justifications, nor indicated how the Sentencing Commission and individual judges were to weigh them.

Washington, D.C.'s government is dependent upon Congressional funding. However, like any state, it may use its internal police power

102. The House Judiciary Committee declared:

Sentencing courts should not use the defendant's need for correctional treatment as the justification for imposing a prison term or determining its length. This does not mean, however, that rehabilitation programs within the bureau of prisons should be cut back: The Committee remains strongly supportive of voluntary in-prison programs. Rather, the provision emphasizes that the unpredictable nature of the rehabilitative process makes unfair the use of rehabilitation as the rationale for imprisonment.

House Comm. on the Judiciary, Sentencing Revision Act of 1984, H.R. Rep. No. 1017, 98th Cong., 2d Sess. 54 (1984) (footnote omitted).

103. See Senate Comm. on the Judiciary, Continuing Appropriations, Comprehensive Crime Control Act of 1983, S. Rep. No. 225, 98th Cong., 2d Sess. 50, 67-68, 75-77 (1984), reprinted in 1984 U.S. CODE Cong. \& AdMIN. NEws 3233, 3250-51, 3258-60 (rehabilitation retained as a purpose, a goal, of punishment, but rejected completely as a justification or basis for the length of the sentence). For an early statement by one of the prime movers of the congressional drive to reject rehabilitation, see Edward Kennedy, Toward a New System of Criminal Sentencing: Law with Order, 16 AM. CRIM. L. Rev. 353 (1979). The Comprehensive Crime Control Act of 1984, which established the Commission, was a product of a bipartisan coalition including prominent Republican conservatives and liberal Democrats in the Senate and the House.

For an essay which argues a criminal's constitutional right to rehabilitation, see Edgardo Rotman, Do Criminal Offenders Have a Constitutional Right to Rehabilitation?, 77 J. CRIM. L. \& Criminology 1023 (1986). 
consistent with local views. Thus, although the U.S. Attorney General nominally supervises the D.C.D.C., ${ }^{104}$ under "home rule" the Department may espouse a correctional philosophy different from Congress. With no mention of punishment or retribution, the D.C.D.C. Master Plan declares itself

based on a philosophy that sees the Department as a "change agent" in the lives of its wards and that places responsibility for change on the shoulders of the inmates. The Department of Corrections must create an environment in which inmates become aware of the need for and opportunity to change and then choose to pursue the options that are available to them. ${ }^{105}$

In several hours of conversations, Walter Ridley, Acting Director of D.C.D.C., and Administrator David Roach, both devoid of anger at the residents, enthusiastically embraced a rehabilitative socio-medical model as the primary purpose of a secure facility. "The rehabilitative process is an inward process, but the Department of Corrections has the obligation to create an environment conducive to that," said Roach. "We would be remiss in our responsibility towards them if we didn't take the attitude that "we want you to become a better person." "On entering the system, each "resident"-a "ward of the court"-should be thoroughly tested, and professional "counselors" should fashion for each individual a "treatment prescription. Each resident must attain realistic goals that he sets for himself." The "staff" inside Lorton Central is "paid to supervise" that process. "I don't believe that the officers are merely guards. And I don't think the inmates are merely prisoners. You can condition people to do constructive things if you're willing to pursue things aggressively enough."

Although the inward process of rehabilitation must be voluntary, the environment most conducive to it may be coercive. "Over the years we have not been aggressive in saying, 'Look, you committed a crime, you got convicted, and you're here to do your time. Here are the rules and regulations that you will live by.' Once we get that degree of conditioning accepted, then we go back and we say, 'Look, we have tested you. Your academic level is grade four. Now, you're going to school every day, five days a week for two hours. We make sure that you go. We're going to positively reinforce you. As you reach each level we're going to give you a certificate. We're not going to give you the opportunity to slip back. We're going to give you a treatment program and see that you adhere to it until you leave here.

" 'You're going to work five days a week, or you're going to be in

104. See United States v. District of Columbia, 703 F. Supp. 982, 991-94 (D.D.C. 1988), for a discussion of the Attorney General's supervisory authority. To avoid prison overcrowding, the D.C. government in this case argued for greater authority by the Attorney General than it may one day wish to concede for other purposes.

105. District of Columbia Department of Corrections Operational Master Plan i (1988) (on file with the Stanford Law Review) (emphasis added). 
school. When you get out in the evening, you can relax, you can do your studies, you can engage in some type of arts and crafts if you like. You can go into the gym and exercise; you can watch a movie on the video machine. That's going to be your leisure time. But in the morning, you get up, shower and go to work.' What we have to do for these twelve hundred men here is to endorse constructive rehabilitation processes, or rather habilitation processes. Let's not rehabilitate, let's habilitate. Let's give people a new work ethic. Most of them already have a drug habit. We're going to give them a work habit. Let's give residents a new self-awareness, a new self-esteem."106

The prisoners give the programs at Central mixed reviews, uniformly praising those select classes like the cooking school which routinely places its graduates in fine D.C. restaurants, and new programs like dental technology. But they complain that at the auto-mechanics shop they are trained in outmoded technology, and that in masonry they spend a lot of time constructing barbecue pits. Much prison industry at Central, they insist, develops skills that are useless or will relegate them to the lowest-paying jobs in Washington, D.C.

"The biggest complaint that people have here is that they're not given an opportunity to prove their worth," said Henry Daniel. "They're not given an opportunity to bring out their potential."

In its 5-year plan that runs through 1992, the D.C. Department of Corrections places great emphasis on the further development of diagnostics and programming. But as Dr. Reynolds summed it up: "Rehabilitation is not something that you can force on somebody. They can be forced to be here; they can be forced to do things, good things; but you cannot force them to understand the value of that."

"Every institution offer some things towards rehabilitation," said Leo Simms, "but it's up to an individual to see that he want that or need that."

\section{Relations among prisoners and officers.}

Although the older inmates agree with the administration that a rehabilitative environment inside Lorton Central is a top priority, they insist that even if useful job training, counseling and educative programs were readily available, the interpersonal environment at Lorton Central would remain hostile to rehabilitation.

The prisoners' harshest criticism is directed at the officers, whom they see as malevolent, uncaring, and corrupt. "They think they're better than us," complained Johnny. "They seek to destroy your identity and take your dignity," Pete Arnold agreed. "These guys today," said Ike Cooke, "it's about giving the impression that they're concerned

106. The Administrator outlined a plan by which he hoped to take control of the prison and end " 15 years of appeasement," including a return to prison uniforms and officers in the dormitories 24 hours a day. 
about rehabilitation, but they don't give a fuck. They're in it for the money, or for the impression they have in their own minds of what people think of them."

"They feel like it's their job to keep you in, not help you get out," said Pete Arnold. "Rehabilitation is nonsense," said Scott Walker. "I look at them and say to myself, 'how can he rehabilitate me when he got a problem?' They can't rehabilitate us. They should be rehabilitated themselves."

"All they got are turnkeys, that's all they are," complained Thomas "Butch" Sheppard. "What can a man with a fourth grade education teach you when you got two years of college? Can't tell you nothing about rehabilitation because he don't even know how to spell it. So what can he teach you? Nothing, except how to keep coming back in here. How they going to correct anybody when they need correcting themselves? If you gave them urinalysis, ninety percent would fail it. You see them everyday, scratching and nodding out. And they supposed to correct us? It's a joke. They don't give it the right name. It's not the Department of Correction; it's the Department of Corruption."

It wasn't always like that. "The guards twenty years ago, they knew who you was," said Pete Arnold. "They strived to drive you to see the error of your ways, to march ahead, and get something on your mind: 'Get that shit straightened out, man. You can't be out there doing that. You want to go out there and stay out there." "

"Back then they were helpful," Rodney Honesty observed. "They weren't familiar but they were helpful. Today they familiar but they ain't helpful."

"There used to be a mutual respect. There was a line. Twenty years ago everybody knew their place and they stayed accordingly. Prisoners stuck together and guards stuck together. You stayed a convict; he stayed a guard. Now there's mingling. You don't know who's a convict and who's a guard. Prisoners today don't know that there's a line there. They act more like correctional officers, and the correctional officers act like criminals. Twenty years ago when the work force was predominantly white, you didn't know the guards from the street. You didn't have a relationship before you got here. Now they come out of the same community. Guard might live next door to you. Went to school with you. Your line is erased as convict and guard."107

"But that should lead to even greater concern with the plight of the prisoner."

"But it doesn't," insisted Hines. "If you a guard and you live next door to me, what we going to be talking about? If you're a drug user, can you bring me some drugs? Or if I drink, when you going to bring

107. "Guards and prisoners are drawn from the same culture and they hold many of the same values and beliefs. They share a common language and a common historical experience." G. SYKES, supra note 15, at 33. 
liquor down here? It's not going to be him saying 'I want you to get an education. I want you out of here.'"

"These men and my staff have interacted in the formative years, the embryonic years," Warden David Roach acknowledges. "They grew up in the same environment, went to the same school, traveled in the same social circle. This cuts both ways: It allows the prison to operate in a more harmonious environment, yet it is not totally professional."

Given "fifteen years of utmost appeasement in dealing with this population," said Roach, "what was going on in the late forties, fifties and early sixties in the Department of Corrections" was "the better of the two models" because of the "discipline" and "respect that the resident displayed toward staff, regardless of whether he felt that way inwardly or not. What came out of his mouth, what came through his actions was 'I understand where $I$ am at. I understand who you are. I understand what your responsibilities are to me and mine to you. I am not going to cross that line.' Where we are today is that the resident doesn't realize who we are."

Surprisingly, the older inmates agree with Roach that although the prison twenty years ago was run by fear, with more discipline, and with corporal punishment, it was on balance a "better run" institution. "No one's really running Lorton. Neither the correctional force nor the inmates," complained Alvin Hines. "Twenty years ago you knew who ran it, you knew what to expect. Now you have an inmate around here for a month without changing clothes. Twenty years ago if they caught you two days with a dirty shirt on, they take you to the bath house, see that you take a shower and be sprayed and give you five brand new T-shirts. 'Come back to me every three days and let me look at you. See how your appearance is. If it's not right you're going to the hole. There's a 'no care' attitude today on the part of the Department of Corrections. Everybody trying to outdo each other doing nothing."

Officers' inconsistency, arbitrariness, as well as their indifference makes the old-timers long for the old days. "The jails weren't tough then," said Alvin Hines. "In the sense that you knew what was expected of you. Now you don't. The rules twenty years ago didn't change. Now the rules change with every incoming officer. Today it's this way, tomorrow a different way. ${ }^{108}$ Twenty years ago every officer maintained the same set of rules. You knew what was expected of you .

\section{8.}

[E]ach officer has to make his own judgments and sometimes his own rules, but his formal authority makes little or no provision for such ambitious uses of discretion. ... As a result, the guard often feels he is out on a limb, subject to being second-guessed after every decision. The notion that one is "damned if you do, damned if you don't"- and likely to be thought incompetent in either case-applies with a special urgency to the guard's situation.

R. Johnson, supra note 26 , at 125 . 
... Now you don't know what will happen to you. This officer might lock you up. This one might not. He might give you twenty dollars."

"One officer will write you up for wearing a certain color hat," complained Ike Cooke, "and the next officer will ask you if you can get him one just like it."

"People live in fear of the administration back then because of the repulsive measures they would use," said Reggie Brooks. "Now they live in fear of the administration, if they have any at all, for the privileges that they will lose. It's just a different way of treating people as nothing."

"It was fear because it was a white person involved. That inmate back then was scared because he would have been attacking the whole power structure. It was their job to instill fear and if you messed up, they had a goon squad that would jump on you and break you up. The black guard today in no way could walk up and think he could force the same kind of fear on these dudes that white guards could force twenty years ago. They can't do that. Now it has to be run this way because he knows in his heart that the inmate is not scared of him. If the black guards tried to pull this on these dudes they would actually attack those guards. The guards are more afraid of the inmates than the inmates are of the guards."

"Inmates have more of a tendency to change staff than staff do to change inmates," observed William Hedrick, former Acting Administrator of Central. "When you order an inmate to do something, he knows how far you'll push and when he can back you down. Inmates are the best psychologists in the world."

"What goes on between the inmates and the officers at Central is a lot of negotiation, and decisions that otherwise should be made cannot be made-difficult decisions," Dr. Reynolds observed. "Negotiations become necessary because of the architecture." At Maximum, with its individual cells, the administration can always lock down the inmates. But on the other side of the wall, out on the compound at Central, "if the inmates decide en masse to come out, there is nothing the administration can do." As a result they have no control. "Furthermore," said Reynolds, echoing the views of older inmates, "there is not that much division between officer and inmate, not all that great a difference in the ethical standards between the inmates and the administration, which means, of course, that it is impossible for the staff to rehabilitate anybody."

One prisoner pointed out a female officer, who used to "babysit me when I was in the crib. I remember once she gave me a terrible asswhipping for touching her titties. She watched me grow up. I watched her shoot dope."

"See that "officer," an inmate asked contemptuously. "He used to bag my dope down on the street. Now he's guarding me!" 


\section{Relations among prisoners.}

Through our conversations, we'd been shown how rehabilitation was undermined outside by society and in the streets to which the released convict returns, and inside by the prison architecture, program administration, and erratic, informal, and sometimes criminal relationships between guards and inmates. Although many prisoners readily pointed to others' failures, some took a share of the blame on themselves, collectively or individually. Inside Lorton Central, rehabilitation rests upon relationships among prisoners.

"The administration say we were put here to learn a better way," Danny Bethel complained, "but how can you learn a better way when your next door buddy is selling you boat, or coke, or introducing you to something? You say 'Man I thought they locked me up!' And you getting high, and watching the TV."

"In the old days, when I was coming up," said Rodney Honesty, "the old guys would teach you about what was happening. In your dormitory, the older guys would sit back and observe you. If you were crazy they'd pull you up: 'Hey, what you doing? What kind of time you got? You got to do something to help yourself.' But now they don't do nothing. We just step back and let the young ones go ripping and running."

"Why?"

"I'm just trying to go home. See, if I do approach them, whenever I approach them, whenever I approach anyone, it's a death threat. I don't want to kill nobody for busting in line. Because it's not going to just be a fight. It's a death play. Everything's a death play here."

Several old-timers support Honesty's observations: Many want to help the kids but are frustrated. "These youngsters of today will not listen," complained Harold Monroe. "They think they know it all, already. They will ask me and then turn around and answer themselves. It's happened many times. I would like to pass on to them what was passed on to me, but they won't listen." "I don't waste a whole lot of time with children nowadays," observed Earl Grier, "because they're lost. Ninety percent of them don't know their own history. Ninety percent of them can't count. All they know about is drugs. And to keep beating your head against a wall is doing them no good. It's best to let them go. Because down that road somewhere they will learn ... or die."

Many other older convicts, however, loath and fear the young ones. They see them as disrespectful, violent, uncontrollable, and "not about anything." "The hell with them," said Garfield Wells, one of the oldest prisoners. "If they don't want to do something for themselves, there's no use in my wasting my breath on them." The cycle is vicious. A laissez-faire attitude of the older generation toward the values of the young 
is devastating to a rehabilitative process for the young criminals, and, of course, for society, their future prey.

The overwhelming consensus within the institution, we'd seen, was that rehabilitation was voluntary and must fail unless and until an individual desires to change. While many inmates did express that genuine desire, many others, mostly younger, even with the tape recorder in full view, nevertheless cavalierly rejected rehabilitation. Typical was this exchange:

"I'm going to tell you the truth like you said. They let me out of jail tomorrow, I might do the same thing. Cause I like money. I'm that type of person, I know what the consequences going to be if I get caught. I will come to jail-you know I ain't ignorant. No one influenced me to do what I did, I chose to do that. I knew what I was doing. If I get caught, I get caught; do my time and come back out. That's the kind of attitude I had."

"From this experience what have you learned?" this street-level drug dealer was asked.

"I learned a lot from being around here. Talked to a lot of guys. I still got street sense in me, Man. I'm going to tell you, I'm going to hustle when I get out. I've learned. I'm not going to hold nothing for nobody else. Only for myself, so I'm getting every dollar."

The inmates who did express a desire to change locate the problem neither on the streets, nor in Lorton or its officers and inmates, but within themselves, individually. "No program, no institution that they have in the country-and I've been to a few-can rehabilitate a person. It's up to a person to rehabilitate himself," said Leo Simms, a man most determined to learn how to live free. "A person can do that regardless of what circumstances-whether it's a close confined environment, or a loose environment like here in Lorton. It's on the individual-what he wants, what he feels about life, what he feels about himself and what he's willing to do for himself-to make the change."

In several extended conversations, Leo Simms revealed both his utter dedication to making whatever changes might be needed, and his awareness of just how much was required: "Every time you get busted you say 'Good God, I'm going to change that!' But no sooner do you get back out there, then the old things drift back in. I really didn't know how to make a change. I stopped trying to find a whole lot of excuses and reasons for doing the things I did. I just stopped doing them because they're no good for me. I've changed my values. I can't afford a Cadillac so I'll take a Ford. I'd rather be on the street where I might be able to pick up on the ground a dollar than be here in Lorton and pick up on a shank or a stick on the side of my head. I'd rather be able to go to a restaurant and order some tasty choice than have them feed me here what they want to. I changed my values. I can buy the Sunday newspaper, and sit down an hour and read it if I want to, with- 
out having to move for the count, or rushing the paper to somebody else. These type of things that don't cost you nothing. It's the little things that I've overlooked in my life.

"That 'later on' has been the cause of too many downfalls. It don't start tomorrow. It start now. I'm the same guy now as I'll be in the street. So what I got to do, what I'm doing, is start now. The changes I need to make are the changes I need to make, period. Not when I get out. Immediately.

"I'm not receiving any kind of professional help. I'm kind of against psychiatrists and all that jive. 'Cause I believe that if you really want to, you can do it yourself. Each individual has his own way-like drugs-to stop doing. So what I be practicing on is self-discipline. Saying 'no.' Not being deviated from a plan. Get up in the morning. If I say I'm going to breakfast, I don't care what happen, or who ain't going. I'm going to breakfast. If I make a plan as small as going to the gymnasium, if it's part of my program, I'm not going to let you or John Henry deviate me from doing that, because I realize that many times in the street I start out, head up town, run into a nigger, who say 'where you going?' I say 'where you going to?' He say 'I'm going downtown.' I'm already half-way uptown. 'You going downtown?' So now I'm on my way downtown. On the way downtown we meet another nigger. 'What's happening babe? Where you all going?' He say 'Listen, let's go crosstown.' Now all three of us, no direction of my own .... I got to get out of that," Leo said with self-mockery. "I've got to give some concrete to my thought. I've got to give some value to what I want to do and let nothing divert me from that.

"So I'm practicing here and I've found that over practicing, things get better and they get larger. The same way with my reading and writing. I never been one to take time to do that. I assumed it just happened to you by living. But you have to make it happen. I make myself do it now. I may not read the type of literature that you appreciate, but everyday I spend an hour reading, because it helps me. I take my time, and get away from people, and look at myself. How did I spend my day? Did I do what I said I was going to do the night before? I pay attention to how I'm going to spend my time. Now I'm working on my cigarettes. How many am I going to smoke this day, and try not to go over that.

"Rehabilitation to us means a total change in our life. Not just not hustling no more. Hustling and jail go hand in glove. We recognize that. But there's more to it. There's more to us that's missing, that we don't have together. So many other things we need to be done to rehabilitate that we don't give thought to, that causes us to do certain things, and want to stay familiar with certain things. A lot of us come back because we get focused on a certain avenue of rehabilitation instead of looking at the whole picture of us. 
"We say 'OK, I'm not stealing no more. Or doing dope or rob no more. Or do things that put me in a position to come back to the penitentiary.' But it's a whole mentality we carry. We could be on a corner, not hustling, and another dude be hustling and something occur and our mentality make us get involved in it, and we don't even get no money from it. So we have to rehabilitate ourselves, whole complete. We say we're not going to commit wrong, but we'll go to places where wrong is committed and that's going to make us just as vulnerable.

"That's where we miss what's going on. But if you redo the whole scope like it's supposed to be done, you won't have to worry about none of that. But we try to keep some of the traces that we like and enjoy. That still will leave us vulnerable to come back to the penitentiary. I don't care if we never rob no more, or do dope, we still vulnerable. Because the way we conduct ourselves, the things we are comfortable with. I can't just scoop out one or two things and say 'I'm not going to do that.' To be totally honest with myself, that just won't keep me out of the penitentiary. There's a lot of things that we like to keep. We like to keep in the know. We like to keep a certain image we have had in the years with certain people."

"Maintain the image, maintain the reputation," Johnny echoed.

"Get to the point where we make a total change," Leo responded. "Because there's no one thing that makes you keep coming back to jail. There's so many things involved-so many personal things involved in you that you don't really want to accept. You just accept what you can see right off. We know that if we put a gun in front of someone's face, then we vulnerable to coming back to the penitentiary. But are we conscious that you could be standing with me, and I'm an old buddy of yours, and if $I$ got a pistol in my pocket and use it, then you going to the penitentiary too?"

"So in other words," said Johnny, "if you decide to let go, then you making a big sacrifice."

"I don't call it a sacrifice."

"I call it a sacrifice," Johnny insisted, "because there's never going to be a time when I come down the street and see you that I'm never going to stop and say 'Hey Leo, what's happening?' I made up my mind to change the complete picture, but it's not going to make me stop from being your friend, because I know that you still sell dope and you got a pistol."

"You want my personal opinion on what you're saying?"

"Let me finish!" snapped Johnny in rare annoyance. "Then the police come, and you selling dope. They going to snatch my ass up too. Look at my record. And I'm going with you. And there ain't nothing in the world that's going to make them believe that we ain't together. That I just happened to come down the street. If you tell them that, they're going to laugh. So do I pass you by?" 
"That's what's going to keep us wronging," said Leo. "This is my opinion-it don't have to be yours. Those little in-between things that we try to hold on to. You and I are no good for one another if we're not moving along the same avenue. Simple as that. We are friends, and we will be friends in heaven. We've established that. It might be ten years before we see each other again, and when we see each other we will be friends. But as a friend I want you to go on and build your life. Be a friend to yourself first, then you are a friend to me."

Leo took a breath, his voice solemn: "If I pass you on the street; I'm not going to stop for you. I'm going to pass you by. 'There goes my old buddy John,' I'm going to say to myself. But I'm going to keep rolling Joe. 'Cause I'm taking my best friend along where I need to be, and that's me.

"Life is all about you. It's about me. When they put me in a box, they put me in by myself. They going to put John Allen by himself. And when time come to answer for whatever, you got to answer for you, and I got to answer for me. I can't say 'My buddy John and me ...' 'cause it ain't like that. God gave me life to work with, it's on you how you wo:k with it. You got to keep moving. For one of us to stay in the rehabilitation thing, we've got to make a complete change. And be about it."

"Be all about it," Johnny and Leo said in unison.

\section{Building better criminals.}

With all the reasons to fail, can rehabilitation ever succeed? Some critics oppose rehabilitation as simply impossible. Johnny disagrees. "People do change, they really do." Sometimes perversely.

Wade Briggs had entered prison an undisciplined drug addict, but left it, ten years later, by his own account a much "improved" person: "Now I be standing around the alley, all around me people be using drugs, smoking their little love boat, or sensimilla, or drinking their Remy or Dom Perignon-into their thing, offering me some. I'd say 'no' and they'd say 'you still got that prison discipline.' I'd say 'there's a time for everything; right now, this ain't the time." "

"So your discipline that you learned at the institution carried you over," said Johnny. "Or you carried it over from the institution to the street and it worked well for you."

"Very well. I'm standing there with my arms folded, dressed in all black, my face all broke down, saying death all over. Really gave me a status."

"It made you able to maintain your people better," explained Johnny, "the people that you had under you, and increased their dayto-day respect for you." 


\section{Why bother?}

Utilitarian critics may reject rehabilitation as too expensive, a waste of time and money, a misallocation of scarce resources better spent in preventing the formation of a criminal than in reforming one who has already harmed society. Retributive critics like Kant attack rehabilitation as a violation of a human being's autonomy: Society must respect every individual's innate personality, and never manipulate a prisoner as a means to our ends. This might justify executing the criminal, but never experimenting upon him, or reconditioning him. ${ }^{109}$ Some younger inmates hold this view, rejecting coercive rehabilitation: "The administration don't have a right to change your thoughts," insisted Rodney Hunt. "The administration have no right to change me," asserted Robert Moffit. "They do have the right to try to change me." The harshest critics of rehabilitation, often retributivists, reject it as unjust: Rehabilitation is more sad proof that crime pays. For the criminal who does not get caught, it pays in ill-gotten gains; for the one who does, it pays in valuable skills and opportunities.

"What about the right of society to say 'we're angry! You hurt people needlessly: We want you to suffer." "

"You're absolutely right. Society has a right to say that," Itchy Brooks replied. "But when it expresses that, it should also deal with its obligation to bring me out as a well-rounded person who is able to fit back into the community. A person who can add something to the community. Society has a responsibility-an obligation-to 'protect, discipline, reform and rehabilitate.' They owe that to you. And if you come here and you don't get it, something is wrong."

"Why do we owe you anything? You hurt innocent people; you left a grieving widow. We're angry. You owe us."

"It's a mutual thing. Maybe I got a value system when I came in where I didn't know that I owed you. You got to make me know that I owe you something. You ain't going to do nothing by stepping on my neck but make me mad."

"But the angry citizen says, 'Hey look, what Itchy's suggesting is that we give a guy in here a better environment to develop himself than the innocent poor out there who have never committed the crimes. We're not giving them structured schooling, counseling, job training. Is that justice?"110

"Isn't that what Jesus did?" Itchy replied. "The prophets helped those who needed help. The ones that seem less likely to need your 1965).

109. Immanuel Kant, The Metaphysical Elements of Justice 100-01 J. Ladd trans.

110. "Conditions inside must not be made preferable to life in the stinking alleys from which the prisoner came." H.L.A. HART, supra note 25, at 165 . "[T] he worst condition of the free man must be better than that of the offender, otherwise the free man will be encouraged to improve his [lot] through crime." P. BEAN, supra note 7, at 186. 
help, I mean, you'll get to them, but they're busy helping themselves. We're talking about people here who don't know how to help themselves. Some people are incapable of making the change. It doesn't matter what the circumstances are. But for those that you can change, you have an obligation in Corrections to change them. For why name it 'Corrections' if you ain't trying to correct something?"

\section{F. The Unjustified Experience at Lorton: A Summary}

Traditionally, the principal definitions, justifications, and purposes of punishment-retribution, general deterrence, specific deterrence, incapacitation, and rehabilitation-have been singly advocated in the literature. Inside Lorton Central they have been singularly violated.

Some inmates do experience retribution-the infliction of pain and suffering they "deserve" because of the crimes they committedthrough the fear, uncertainty, and boredom that pervades their daily lives inside Lorton Central. Lorton is for them a "hell hole." However, other inmates' experience of Lorton Central as a "sweet joint," where they play basketball, get high, dress well, work out, have sex, and watch color television is the antithesis of retribution. Moreover, by severing the crime committed outside from the quality of time spent inside, the guards, the prisoners, and the prison's administration further undermine retribution: The short-term, first-time offenders suffer most, while the most hardened criminals-with the best contacts, the best hustles, and the best jobs-enjoy the softest lifestyle. Inside Lorton Central, those who most deserve punishment experience it the least.

General deterrence succeeds with the uncountable multitude whose fear of imprisonment causes them to forgo crimes. But it fails with others, who do not factor into their decisions the risk of going to prison, or the pain and suffering experienced inside it. Still others are undeterred because, in their cost-benefit analysis, criminality is profitable: The rewards seem great; the risk and costs seem small. Deterrence fails when prison seems an acceptable, perhaps inevitable, part of life; it fails when distorted images from family visits subconsciously create an impression that prison is a good place to live; it fails when people continue to look up to the incarcerated as heroes; and it fails when one criminal's sentence merely attracts to crime another, who fills the slot of the fallen.

Lorton Central does incapacitate prisoners: During the inmates' "time" inside Lorton, society outside is generally safe from their predatory ways. But inside Central, crime runs rampant, and many inmates prepare for new crimes more serious than those which landed them in prison. Incapacitation confines the inmate to prison, but not within it.

Unpleasant memories of their time served inside Lorton, coupled with a new awareness of the effects of incarceration on their families, may specifically deter some ex-convicts. But an experience inside Lor- 
ton Central fails with those who easily forget; with those who, through a long absence, have lost their family ties; and with those who feel they have dealt with prison and could deal with it again. While images of Lorton fade, the streetlife again attracts the ex-convict to crime. Time spent inside Central-a crime factory-has made many convicts more cautious and skillful in finding illegal opportunities and avoiding apprehension. Perversely, for some, prison becomes a refuge, a place to escape from the pressures of freedom.

A long confinement inside Lorton Central rehabilitates a very fewby most inmate counts, less than five percent-who acquire new skills and, perhaps through maturity or a new sense of morality, upon release value their freedom, their families, and the society from which they have been separated. But for the bulk of those released, rehabilitative programs are only another "con." Street pressures, a lack of legitimate job opportunities, a loss of family ties (or overwhelming family demands), a lack of personal commitment, and old familiar habits combine to return them to old ways, and eventually to Lorton Central. Some prisoners who do acquire discipline and shed a drug habit from a decade in prison, return to the streets, ironically rehabilitated: Sober, patient, and self-controlled, they are able to hustle more effectively.

In short, inside Lorton Central some prisoners, content to spend most of their adult lives incarcerated, languish in a drug-induced stupor, while other prisoners, "ripping and running," become more dangerous and less redeemable with each passing day. Inside Lorton Central we discovered a truly perverse integration among these competing purposes and justifications: all failed together.

It is easy to blame the D.C.D.C. for the prison's dismal failure. Doubtless, fifteen years of appeasement have contributed significantly to Central's slide into anarchy. Prior administrations yielding piecemeal to expediency, found it next to impossible to make wholesale changes in an era of limited budgets, opposed by influential members of Congress, especially those from Virginia, who reflected their constituency's fear and hostility toward an all black prison complex under a 99-year lease, which posed some threat while making no substantial contribution to the economy of the surrounding communities. And could any administration have truly changed the inside without changing the outside, the conditions in society which breed crime, the economic struggle for survival which engulfs officers no less than inmates? 111

Lorton Central may be unique among prisons in the United States, but in its failure to achieve the traditional goals of punishment, it suf-

111. If the present administration actually fulfills its clearly and coherently articulated goals, and produces secure, humane confinement in an environment conducive to rehabilitation, while conveying the message that crime will not be tolerated, then the D.C.D.C. should be congratulated, even by those who disagree with its lack of articulated retribution. Besides, if "home rule" means anything, the District must be permitted its penal philosophy. 
fers their common fate. The problem may lie in the categories themselves, used for centuries by legislatures, courts, philosophers, and law professors, with a most casual relationship to reality.

Any society determined to measure a prison's success primarily in terms of retribution, deterrence, incapacitation, and rehabilitation, may be doomed to failure. Searching for a workable blend among these concepts, a twentieth century integrativist may compound the self-delusion. Yet these categories are so ingrained in our way of thinking about crime and punishment that they seem inescapable lenses through which punishment must be viewed. In any event, we are incapable here of substituting others.

\section{ADVOCATES FOR REFORM}

Can these traditional categories that confine us be used to alter that experience which they condemn? Suppose a new mayor of Washington, D.C., with a supportive Congress and a U.S. Attorney General eager to cooperate in reconsidering the philosophy and practice of the Department of Corrections, were to summon advisors, each personifying a different perspective. How might these advocates translate their theories of punishment into blueprints for change?

\section{A. An Incapacitationist}

Even if Lorton Central has no real impact on the problem of street crime, an incapacitationist insists that the prison's primary purpose is to remove criminals from society. A prisoner should be sentenced to a "double" loss of liberty-"first by confinement to the institution and second, by confinement within [it]."112 The administration's primary responsibility, therefore, is to maintain a secure facility, inside and out.

No prison is escape-proof, but the incapacitationist demands that escape be made as difficult as possible. Budgetary as well as political pressures undermine this. Ground sensors around the perimeter, for example, are expensive, and after they were disabled during road construction they were not immediately replaced. And although the D.C. Government may find electrified fences symbolically distasteful and politically unpalatable, the concerns of the surrounding communities in Virginia must be accorded higher priority. Electrify the outer perimeter. If a prisoner hallucinating on PCP is electrocuted climbing the fences, that is an unfortunate cost of effective incapacitation. Alert and drug-free guards would be imperative.

Escape from Lorton Central comes in many forms: scaling the fence, walking out disguised as an officer or visitor in clothing fashioned at the tailoring shop, altering records to effect an early release or

112. G. SYKES, supra note 15 , at 65 (emphasis added). Gardner notes that the distinction between "imprisonment as punishment" and "imprisonment for punishment" is one likely to "escape judicial sensitivity." Gardner, supra note 10, at 792. 
to avoid disciplinary action. Conning the parole board into believing the criminal has reformed is also a form of escape. If a psychological dimension is added, to be high on drugs is to escape punishment. A greater officer presence in the lives of the inmates would diminish the risk of all these.

Prisoners confined to Central must also be confined inside it. As long as they can roam the prison and commit crimes against each other, inmates are not truly incapacitated. Lorton Central today is a crimeinfested "death trap," as Ike Cooke explained, "because there's so much you can do. You move freely from the time the count clears to the time they call another count. I can be in my dormitory asleep and you and I could have just had an argument, and you can walk in my dormitory — broad daylight, night, whatever — walk right into my dormitory and stab me in my sleep. Unless someone else sees you and reports it, they'll know I've been stabbed, but nine times out of ten, that's about it. I feel threatened-all day, everyday." The incapacitationist would support a system of controlled movement which requires prisoners to be at a specific place and accounted for at all times. Only for a few minutes each hour would the inmates be permitted to move quickly from one location to another. Since prisoners ordinarily do not keep weapons on their persons or in their lockers, but hide them in a readily accessible place, controlled movement would decrease a prisoner's access to his shank and his target, decreasing violence.

Prisoner Pete Arnold reluctantly agreed that controlled movement would be a "good thing, because when you don't have no movement, you don't have nothing happening. Guys can't make but so much happen." Most prisoners, however, oppose controlled movement. As Johnny Allen said, it "cramps your style." But even opponents recognize its effect on reducing crime inside the prison. Asked if he agreed with controlled movement, Ike Cooke replied, "After being here for so long, for reasons of enjoyment I don't." But after hesitating a moment he added, "But for reasons of protection, I do go along with controlled movement."

Prisoners inside their dormitories must be protected from outside attack. In addition to controlled movement on the compound, each dormitory should be equipped with doors that lock from the inside with alarms that sound whenever the doors are opened. At no time would a prisoner without authorization be allowed in a dorm not his own, and most inmates should be allowed in their own dorms only at specified hours. Officers stationed in each dormitory can significantly reduce crime, including nighttime attacks on sleeping prisoners. Of course many prisoners vigorously oppose the presence of officers as an intrusion into "their" dormitories. "For the people who need them in the dorms they should be in the dorms," admitted Curtis Smith. "But not for me. I mean I do too much wrong, and I get high too often to have the police stopping me. But yeah, to do their job they should be in the 
dorms. Of course I don't want them there. But they should be there." Other officers should be stationed on the compound to prevent unauthorized movement, especially at night. Further to protect inmates from each other, Central should contain an adjunct wing of individual cells into which an inmate can lock himself, for as long as he wants, no questions asked. And to prevent crime even by a large, organized group of inmates, the administration must be able to lock down the entire inmate population.

Converting the whole institution into a maximum security facility composed of individual cells instead of dormitories would offer prisoners fuller protection from each other. Although reconstructing Central would be expensive and require congressional funding, given the nature of Central's population, its present design and classification as a "high-medium security" prison is absurd. A recent killing at Maximum's CB-2 (cell block two), however, demonstrates that even the most controlled setting will not prevent all violent crime. One prisoner, locked inside his cell 23 hours a day, managed to fashion a shank from the metal strip lining the window frame, sharpened it on the cell's concrete floor, and at a moment when the guard's attention was diverted, stabbed his target in the shower.

Prisoners fabricate weapons out of almost anything, and with its sizable industrial facilities, Central will always have some weapons. The furniture repair shop, tag shop, plumbing shop, and metal shop are all prime sources. Prisoners report that the grinding wheel is not always under lock and key, and when in use, not always guarded. Industry, although physically located inside the institution, is under a separate authority. This system of dual command inside Central fosters security lapses. The authority of the warden of Lorton Central must extend to every inch of the institution.

Possession and acquisition of narcotics are crimes which cause assaults, thefts, and homicides. Routine urine tests of officers as well as inmates should be administered, ${ }^{113}$ but without visual supervision the tests are easily distorted. Substantial penalties would attach to "a dirty urine." Visitors routinely smuggle contraband-including money-to and from Central. Although superficially searched for drugs and weapons, they are allowed to carry money and wear jewelry inside the visiting hall. This should never be allowed. And a threat to eliminate visits would greatly reduce smuggling.

Undercover agents could detect corruption among officers and de-

113. Drug testing programs have been held constitutional in similar contexts. See National Treasury Employees Union v. Von Raab, 109 S. Ct. 1384 (1989) (approving the United States Customs Service's broad drug testing scheme); Skinner v. Railway Labor Executives' Ass'n, 109 S. Ct. 1402 (1989) (validating the Federal Railroad Administration's drug testing program which required railroads to administer blood, breath, and urine tests to employees involved in major train accidents). 
ter crime among inmates on the inside. ${ }^{114}$ Members of the D.C. police department's integrity unit, or federal agents, should be introduced into Central, working as officers, or living as inmates. These undercover agents, who can most closely monitor the prison from the inside, should never pose as vocational, psychiatric, educational, or medical staff, lest the inmates distrust those whose primary purpose is to help them. Entrapment, of course, must be avoided, but let all prisoners and corrupt officers fear that a potential co-conspirator might be an undercover agent. The only guards prisoners could trust would be the "straight" ones.

Incapacitation, however, may be at odds with itself: Inmates predict that if the administration dries up the institution, reducing drugs, and decreases sexual access to visitors and prisoners, rape and other violent attacks on the inside will increase. Maximizing incapacitation, apparently the least controversial goal, may undercut specific deterrence: "The young guys are running buck wild in here, and you think that by corralling them it's going to do something to benefit them, but it's not," said Itchy Brooks. "It's going to make them worse; it's going to bring up the anger, the frustration, the anxiety in them that they had different outlets for. And it's going to be a worse situation when they go out."

In short, the incapacitationist would urge the Department to retake control of Lorton Central, tighten security, and decrease crime inside, by immediately instituting controlled movement, outfitting dorms with a lockout and lockdown capacity, stationing officers in the dorms, sending undercover agents into the institution, and giving the Administrator full authority over the entire institution, which eventually should be converted to a maximum security facility.

\section{B. A General Deterrence Advocate}

For some critics like Professor Philip Heymann, "it is a mistake to think that the answer to the purposes of punishment can be found inside the prison walls." For them, "the primary function of punishment is to keep the middle class content and law-abiding, allowing them to believe that at least for the criminals who have been caught, crime does not pay. In the end, punishment only keeps society from feeling like they are suckers for being law-abiding."

"Yes, prison incapacitates me," Pete Arnold said, echoing this pessimistic position, "but it doesn't allow the victim any real relief. If he feels any comfort at all, it's that they got that sonofabitch. But it's got to be more than that."

Too humanitarian to claim vengeance as a goal, and too realistic ${ }^{115}$

114. See Tamar Jacoby, $A$ Webb of Crime Behind Bars, Newsweek, Oct. 24, 1988, at 76-78 (reporting a successful undercover operation in the Philadelphia prison system).

115. "For those who are too humanitarian to claim vengeance as the goal of confine- 
to hope for real reform in most cases, yet eager for prison to serve some purpose beyond merely warehousing prisoners, a general deterrence advocate looks to the streets for the solution to the problem of crime and punishment. Carefully constructed images of Lorton Central may reduce the criminal behavior of would-be offenders.

The advocate of general deterrence would package and present different images of Lorton Central to different publics. As potential criminals and prisoners, the people should be frightened by their prison; as electors, law-abiding citizens, and potential victims of crime, the people should approve of the very setting which they fear.

A general deterrence advocate would look to bolster the public's perception of Lorton Central as a very unpleasant place, artfully exaggerating the kinds of punishment that a retributivist might urge inside. There is a limit, however, to what can be faked successfully. A mechanical look-alike dummy, writhing in agony at a whipping post, might fool some people temporarily, but in the end truth will out. And as Sergeant Shipley observed, "If the public knew this place, they'd have a fit." 116

Those who hustle in the streets of Washington, D.C., however, are already clued into Lorton, having learned of its reality from siblings, friends, or acquaintances. These young street hustlers do not fear Central. This most relevant public is not deterred by its perception of the prison. It is upon this audience that a deterrence advocate would focus.

Converting Lorton Central to a maximum security prison, with controlled movement and 24-hour officer presence will change its image on the street from a "sweet joint" down the road to a very unpleasant place to do "hard time." The worse this prison is perceived to be, the better will it convince would-be criminals on the outside to forgo crime. And that, after all, is its mission.

Without spending great sums, the Department can nonetheless extract much more deterrent value from Lorton Central. The general deterrence advocate would make altering the image of Lorton to children on the street the Department's primary focus, greatly expanding Scared Straight and similar programs which bring schoolchildren to Central and expose them to its worst face. Wade Briggs emphasized the necessity of consciously presenting a distorted image to the kids: "As far as telling them about jail life, I wouldn't put too much emphasis on 'You can get a good schooling, you can obtain some type of religious belief, proper rest and all that' because those things can encourage him to say 'Well, I'm going to do this until I get caught, then when I get caught, I can go to jail to learn how to read and write.' So I probably wouldn't

ment and too cynical perhaps, to hope for real reform in the majority of cases, the objective of deterrence offers a comfortable compromise." G. SYKEs, supra note 15, at 11 (emphasis added).

116. Ironically, then, this study that Professor Heymann spawned could help dispel the very public ignorance on which depends his principal justification for punishment. 
tell them about that part. I would just tell them about the rough part of it, the part that you got to protect your manhood and all that: 'You going to get into a scuffle with a guy about six feet tall who weigh two hundred pounds, and you going to be the smallest thing in there.' I would try to encourage him that this is not something he would want to experience." With inmate input, and in association with educators, the Department might act on a suggestion of inmate Dean Martin and produce films and children's books, including comic books, about the horrible life inside Lorton Central.

As presently structured, family visits have perverse effects. From these visits, the children of prisoners are branded with their most indelible images of Central-all too often favorable. A ranking member of the D.C.D.C., resisting the idea of imposing prison garb on inmates at all times, once proposed as a compromise that prisoners dress in prison uniforms except during visits and family outings. But, the Department should care much less what inmates wear every day than what they wear on visiting day, when it is most important that they look most drab. Perhaps they should enter the visiting hall in ball and chain, unlocked in the presence of their children. Not surprisingly, prisoners vehemently oppose this suggestion. "It's going to work both ways," insisted Johnny. "They're going to have that terrible, horrible picture of their father like that, and they're going to really, really resent the police." Itchy agreed. "It will make them vicious against authority. I don't want them to see the authorities as unnecessarily brutal people, because that's the picture that I grew up with, and I know what that can do."

The principal deterrent effect of the prison on our children, however, must occur on the street. "Deterrence has a lot to do with images and values," inmate Pete Arnold observed. "They are interrelated, interwoven. It don't take but one guy in one Cadillac to stop in five neighborhoods and fuck up five hundred kids. See we ain't talking about no army riding around like Patton. We talking about a few people who have been successful in what they do, that should be right inside here with me, that has perpetuated the image that continues to this day, to poison minds of young people."

A general deterrence advocate would urge the D.C. police to concentrate on the ostentatious criminals-perverse role models who parade the streets poisoning the minds of the kids. These criminals, who most undermine deterrence, would not be permitted to hustle openly and flaunt their lifestyle. They would be arrested on the street, in full view, shamed to the degree legally possible. ${ }^{117}$

And these folk heroes who are now inside Lorton Central must not

117. The U.S. Attorney's office seems to have resorted to such tactics to deter securities law violators. See, e.g., William Glaberson, 3 Leading Brokers Seized on Charges of Insider Trading, N.Y. Times, Feb. 13, 1987, at AI, col. 6 (reporting that two men accused of insider trading were arrested at their offices, one of whom was led away in handcuffs). 
remain heroes to the kids on the street. The same "Joe Slick" whom they last saw driving in style, dripping in gold, draped by beautiful women, should reappear on the street in a "cell on wheels" wrapped in plexiglass, dressed in prison garb, head shaven, publicly shamed. The children will crowd around the chastened criminal, their memories indelibly seared. With "Lorton on wheels," image will be made to counteract image. Psychologists and prisoners could work together to devise other vivid displays which would be effective but not cruel.

If society is committed to deterrence, then the Department should use images of the prison to prevent crime among all relevant publics. Without any additional expense, Lorton Central can be instantly transformed into an effective deterrent for whole classes of heinous criminals: Sending to Central one or two business executives who knowingly maintain illegal ultra-hazardous working conditions, or who illegally substitute inferior components in vital instruments-those for whom killing the innocent is a business decision, a carefully calculated risk-as well as a few corrupt public officials who sell their offices and violate the people's trust, would have a profound effect. Make their fate public, and much of the remainder of this heinous group of wouldbe criminals, mostly white middle class professionals, will forgo crime, terrified to risk a stay inside Lorton.

\section{A Specific Deterrence Advocate}

An advocate of specific deterrence is also concerned with images, especially with lasting memories of time spent inside Lorton Central. ${ }^{118}$ The prison can teach the criminal a valuable lesson he will not forget.

Back in the street, thousands of days inside Central are condensed into brief memories of but a few highlighted moments. Therefore, an advocate of specific deterrence might urge the Department to insure that the released criminal's memories of time spent inside Central are at the deepest level most repulsive, but for very different reasons than those urged by a retributivist.

For a specific deterrence advocate, pain is but a means to an end. The goal is lasting pressure. Not all pain converts to pressure. When pain is accepted as tolerable and inevitable, it fails to exert pressure. Only when future pain is avoidable, can its threat influence an ex-con to go straight. First impressions and final impressions are most lasting; these should be most unpleasant. Typically first-timers feel most terrible at the beginning of their first bit, and for those who are "short" (near release), time hangs most heavily.

"I had ten years; it went like that," said inmate Harry Rowe, snapping his fingers. "Now I've only got a few months and it takes so long." Rowe described a fellow prisoner who was complaining about how hard

118. Manipulation of visitors' memories occupies the blurry boundary between general and specific deterrence. 
his time was. "I looked at him. He had already done ten years. And now he only had to do two. But the two feels like twenty. I never understood that until I experienced it myself. But it's true. I can see it, I can feel it, but I can't understand it. When I was doing my ten and they told me it was time to go to another joint, I said, 'Wait a minute, I haven't even seen the movie yet!' That's how it felt like. Now these last months, I can tell you where I was every moment of each day, day-today. The ten went like that. But this feels like it's going in slow motion."

A prisoner's memory of the joint should be far worse than his average experience. So inside Central, his sentence should be punctuated by intense physical or psychological pain. This phenomenon of "heavy time" can be amplified if the Department adopts a program of layered punishments, and transfers each inmate near release to the prison's most intensely painful setting. Thus he will remember the unpleasant experience that awaits him should he return.

\section{A Rehabilitationist}

The focus of the prison should be its prisoners, many of whom are unfortunate products of genetic predispositions, environmental deprivation and abuse or neglect during early childhood, broken families, sibling and peer pressures to hustle at an early age, narcotics addiction, and economic pressures outside their control. Rehabilitation requires an inmate's desire to reform and, in the majority of cases, an atmosphere conducive to change.

"It's not the person only that has to be rehabilitated," said Itchy. "It's the situation."

"In this environment here you got rattlesnakes, and cobras, and watermoccasins, and all they doing is biting one another. Each one of them is poison," said Henry Daniel. "Everybody's biting. So how you going to get goodness out of that?"

"The secret of success in all programs," Dr. Karl Menninger noted, "is the replacement of the punitive attitude with a therapeutic attitude." 119 The Department's ranking administrators have personally and formally renounced the same "obsolete, vengeful penal attitude" which Menninger condemns. ${ }^{120}$ "I would like to see Central become a model prison that offers a range of programs designed to meet the needs of the offender population that's housed there," declared Director Ridley. "This is a substance abusing population who lacks marketable skills. We're going to have to make an investment in them now." The inmates neither know of nor would believe this concern for their welfare expressed by the Director of the department that confines them. "It's not my job to convince them it's going to happen," said

119. Karl Menninger, The Crime of Punishment 262 (1986).

120. Id. at 280. 
Director Ridley. "I have to expend my energies to make it happen." The rehabilitationist would urge the D.C.D.C. to raise its standards, raise its salaries, screen its officer corps more strictly, demand and reward a constructive involvement in the welfare of the inmates, and discipline corrupt, sadistic, or indifferent officers. In short, the D.C.D.C. should be given the opportunity to implement the philosophy it has announced in its own master comprehensive five-year plan: Secure custody in a humane, supportive environment. ${ }^{121}$

The rehabilitationist would agree that Lorton Central should be renovated to provide maximum security and controlled movement. As Administrator David Roach said, "when you're trying to fight fires every day, when you're trying to protect them from each other, you don't have a chance to set up that wholesome atmosphere." The process of the institution's physical rehabilitation itself offers a prospect for spiritually and vocationally rehabilitating inmates. Multi-million dollar construction contracts could require contractors to employ some percentage of inmate and ex-convict labor as supervisors and workers. ${ }^{122}$ Architecture can once again become the "moral science" that was envisioned in the nineteenth century by the Boston Prison Society. ${ }^{123}$

Much federal money has been spent and corruptly misspent on public housing. The administration should lobby Congress to require HUD construction contracts in the inner city to call for employing exconvict and inmate labor, drawing from the half-way houses and Minimum. The goal inside Lorton Central is to communicate realistic hope to prisoners that they may acquire skills leading to gainful employment and advancement on the outside. The possibilities for new and expanded programs are endless, limited only by budget and personnel.

The Department should seek to create an environment in which inmates who want to change have an opportunity, often their first, to discover themselves and realize their potential. Every resident in the United States-inside or outside prison-should be literate, understand elementary mathematics, ethics, and the Constitution. Participation in formal academic programs beyond this would be truly voluntary, reserved for those prisoners who request them, knowing that good time will not be based upon higher education completed. On the other hand, college exchange programs could be established where an academically gifted ex-convict can get a work/study scholarship to relocate in a new city. Foundation support would be necessary and the Department could employ skilled grant writers to work with inmates to design, apply for, and implement grants.

121. See notes 104-106 supra and accompanying text.

122. See Cressey, Adull Felons in Prison, supra note 19, at 123 (pointing out that "[p]risons became factories and remained as such until the 1930 s, when businessmen and labor leaders began perceiving them as unfair competition').

123. D. Rothman, supra note 15 , at 83 . 
Educational programs, however, would not be the Department's main rehabilitative focus. Most money allocated for programs would be spent to offer prisoners practical meaningful skills in demand in the outside world. The lack of manufacturing or heavy industry in Washington complicates the problem. Service jobs available in such fields as computer programming, word processing, dental technology, or landscape gardening should dictate program emphasis.

For complete rehabilitation, the prison must offer residents meaningful opportunities and rewards to change their values. Inside, selected prisoners should be able to work and earn money as counselors to younger prisoners. They should also be used in orientation programs for newly arriving staff as well as inmates. A joint resident/staff committee could reward individual inmates who had demonstrated substantial and successful efforts to turn their lives around. ${ }^{124}$

If the D.C.D.C. helps only a few inmates at Lorton Central reintegrate into society and live productive lives, it will have accomplished something significant. But what of the crime problem? The incapacitationist declares the rehabilitation of society totally outside the bounds of the Department. But Lorton Central's most important resource, its residents-especially those older convicts who despair of a lost generation of youth, who know and reject the life of drugs and street hustling - can play a vital role. They could be organized and conditionally released to work among youth, ages 8-15, spending their days inside the schools, and nights on the streets where the kids hang out, befriending children on the cusp of serious criminality. They can best convince the coming generation of what lies ahead. "I know we're breaking the chain from the back end," Director Ridley declared, "but these inmates have an effect on the front end. If they come out as changed, they become change agents, and we need a lot of change agents in our communities today."

Unleash an army of "old" hustlers to help regenerate their grandchildren's generation, for whom it is perhaps still not too late. This program would require government or foundation funding. It would be administered jointly by professional counselors and former hustlers. Incapacitationists might oppose all early release or furloughs, and retributivists of course will strongly oppose this plan, but to the rehabilitationist, justice, humanity and ultimately society's own safety demands it.

124. In 1987 and 1988 , the author made preliminary moves to establish such a Committee for Constructive Change inside Central. Consisting of six members-three prisoners and three staff members-all with staggered terms and chosen from a list submitted by the other group, the Committee's purpose, as envisioned, would be to monitor and reward prisoners who made positive changes in their lives. 


\section{E. A Retributivist}

The administration of Lorton Central should neither seek to change society nor the prisoners themselves, a retributivist urges. The people demand what the criminals deserve-justice-plain and simple. The prison exists primarily to administer punishment proportionate to the seriousness of the crime committed outside. Life inside Central mocks that goal. Inside, criminals who committed relatively minor crimes, who long to return to their families, live in a "death trap," while those who have murdered, raped, and robbed, in the midst of their long sentences, continue to prey on the weak and live a life, in the words of inmate Robert Dent, where "everything they got on the street they got here. They can make babies, or play craps. They can work out at the gym and then if they want, a guy will come in there, lotion them down, massage their backs. Then they probably turn on their color TV, shoot some dope, get high, and lay back...."

As long as a prisoner's daily experience inside is either severed from or perversely connected to the crime committed on the outside, Lorton can never become an instrument of justice. In theory, only the length of a prisoner's sentence corresponds to the seriousness of the crime. The retributivist would link the quality of time inside with the severity of the crime outside. To a retributivist, "how long?" also means how long?

Therefore, Lorton Central's greatest failing is to treat all prisoners alike when they first enter, as if each person arrives with a clean slate. Instead, insists a retributivist, from day one and every day thereafter, more serious criminals should experience greater pain and suffering. The quality of the food, the convenience of the feeding process, the number and nature of visits, access to oversubscribed programs, telephone privileges-every aspect of life inside-would relate primarily to the criminal's past crime. ${ }^{125}$

A retributivist finds it fundamentally immoral and perverse that life inside the joint for the most heinous criminals should be more comfortable than life on the streets for the law-abiding, hardworking poor. The idea of prison is based upon a moral foundation that free time is valuable. For most people, life in society consists primarily of work and responsibility. Their principal reward is "free time"-a few minutes for coffee, an hour for lunch, evenings after work, several hours each weekend, and occasional vacations. Our prisons rest on the moral foundation that a legitimate substitute for the historic revenge on the criminal's body is a deprivation of his liberty, his loss of free time. Retributively, loss of freedom is not only a loss of freedom to move, but also to choose how to spend one's time. Thus, inside Lorton Central an

125. "[W]e must look closely at the types of pain that occur in prison-diet, hard labor, isolation cells-and consider systematically grading these so that the intensity of the prison may be adjusted to the punishment deserved by the crime." G. NEWMaN, supra note 16, at 48 . 
inmate's day and night would be structured so that the most culpable had the most chores and the least free time. Inside Central, prisoners would not spend their days and nights in front of their own color television sets. Most dormitories would have a single black and white television, and initially the most serious felons would have no TV privileges. Only simple radios and not FM stereos or tape players would be permitted.126 These conditions would vary with the nature of the crime committed, but nobody inside Central should be able to flick through the channels by remote control while enjoying breakfast in bed.

Many inmates committed crimes-theft and drug dealing-to acquire and display wealth. As a measure of their punishment, therefore, a retributive prison experience would deny them what they sought on the street-material comfort and display. The Department should dress all prisoners uniformly, in simple prison issue. Expensive athletic shoes and jewelry would be strictly forbidden.

Thieves make the institution of property generally insecure. Retributively, ideally they should experience insecurity with regard to their own property, stored in unlocked lockers. Burglars, who make us feel insecure even in our own homes, should appropriately feel vulnerable to intruders in dormitories which do not lock. ${ }^{127}$ The range of retributive living conditions is endless, but a retributivist demands that the prisoner's lifestyle inside prison be recognizably connected to his crime.

And what of the stickup man who "picks his vic[tim]" at random, and having been handed the money, still injures or kills "for kicks"? One prisoner admitted to the author that he had grabbed a child as she left for school, forced her back to her house, ransacked the house, raped her mother while holding a pistol to the head of her father, and, as he ejaculated, pulled the trigger. What does he deserve? As philosopher Morris Cohen said, "We must hate evil if we really love the good . . . And we must hate evil intensely if we are to fight it successfully."128

Retributively, he who has inflicted gratuitous violence deserves gratuitous violence in return. It has become taboo in the United States and Europe to acknowledge and adopt as policy the intentional infliction of pain and suffering on the body of the prisoner. ${ }^{129}$ Many people

126. Suggesting that a community black and white $T V$ is in any sense a real deprivation is from one perspective ludicrous. But given the overriding importance this prison population places upon private TVs, this proposal would work a meaningful deprivation. A recent decision by New York state regarding cable TV for prisons elicited public outrage directed not only at the increased cost to the taxpayer, but also at the entire concept.

127. Undermining our attempts to employ "legitimated vigilantism" to accomplish likefor-like retribution, is the fact already mentioned that among those criminals who deserve to be preyed upon by other criminals, the most vicious and ruthless will come out unfairly on top.

128. Cohen, supra note 10 , at 1018 .

129. This has been true in Europe for quite some time. 
recoil in horror and dismiss corporal punishment as barbaric. Almost no professional involved with the criminal justice system argues for it in print. One of the few exceptions, Professor Graeme Newman, in his book Just and Painful, urges society to adopt corporal punishmentprincipally electroshock-in lieu of prison, as a more just and less severe penalty for all sorts of crimes, including theft. Strongly condemning the chronic pain of prison's totalitarian hold over the prisoner's entire life, Newman, a thoroughgoing retributivist, argues the superior justice of the acute pain of corporal punishment: "Only the guilty person is punished. The punishment administered is clean, simple, and most importantly convincingly painful. It is over in a brief time, and the offender is able to return to his family and his job. Punishment is confined only to the guilty. The side effects of punishment are minimized."130

Most parents have spanked their children; ${ }^{131}$ many schools allow teachers to strike students when necessary to correct them. ${ }^{132}$ Why are we willing to hit our own children and yet horrified for our agents to strike our violent criminals? ${ }^{133}$ Perhaps those parents who spank their children but oppose corporal punishment treat their own act as a regrettable loss of composure. Perhaps the difference is one of motive. It pains the parents to hit children they love; it pleases retributivists to beat criminals they hate. ${ }^{134}$

Or perhaps the difference consists in the effect. When asked to jus-

But where is our logic, our sincerity in penal matters? Nowadays we have not lost that primitive instinct. When we judge a criminal, we aim always at proportioning the punishment to the standard of disgust or contempt aroused in us by the crime; But we are scandalised and cry out if anyone admits to this.

Cesare lombroso, Criminal Man (1876), cited in S. Sylvester, supra note 61, at 77.

130. G. NEwMAN, supra note 16, at 43. "An important reason why bodily punishments are thought of with such repugnance is that they have been historically linked to the process of torture," Newman observes. Id. at 28. "Corporal punishment should never be used either in combination with prison or in order to 'correct' the offender, because in these uses it comes too close to torture, which is barbaric and destructive." Id. at 141. Rather, to sentence to prison should be a "truly cataclysmic decision," id. at 60 , reserved for the most heinous criminals. Thus, "only two prison sentences should be allowed: 15 years for the first incarceration, and life if the individual recommits after his release." Id. at 140.

131. Ingrid Groller, Spare the Rod-And the Child?, PARENTs, Sept. 1987, at 27 (stating that in a survey, $59 \%$ of respondents said they used physical punishment).

132. Francis Roberts, Corporal Punishment in Schools, PARENrs, May 1988, at 41 (pointing out that corporal punishment in schools has been outlawed in only nine states).

133. "So if it's okay for children, why not for criminals?" Newman asked rhetorically. G. Newman, supra note 16 , at 90 . Newman also suggests it is inconsistent to advocate capital punishment while opposing corporal punishment. Id. at 23. However, capital punishment totally incapacitates, and may be administered as painlessly as possible. Corporal punishment, by its very definition, is consciously painful, and by its effect may make its recipient a more violent criminal, see text following note 41 supra (commentary of Itchy Brooks).

134. Our relationship to our children, these intimate dependents, validates what would otherwise be an assault on a person's autonomy and dignity. Our children-"halfway between man and beast"-are not fully formed and cannot survive without us. We feed their mouths, wash their bodies, care for them, clutching their hands whether they like it or not as they cross the streets-and ultimately sacrifice for them. We are not only entilled to treat them differently than we do full-grown strangers-we must. 
tify spanking while rejecting corporal punishment for criminals, Dr. William Weiss, a practicing psychiatrist, explained, "Children are not yet formed beings. A parent is obliged by society to exercise that influence on a child which is necessary to socialize it. And part of that is giving a child the message that 'if you don't meet certain kinds of expectations, you will suffer pain of some kind.' A child of four or five can internalize the physical pain psychologically, and if administered consistently but not sadistically over a long enough period, the pain will produce new psychic structures and socially acceptable behavior." Administered to an adult prisoner in prison, corporal punishment will have no such beneficial result, he added. Itchy Brooks agreed, vehemently insisting that "no self-respecting adult is going to allow any authoritative-minded sick motherfucker to inflict corporal punishment on them in the name of 'contemporary rehabilitation processes.' They would kill a guard per day at that rate. You should be advocating building self-esteem instead of destroying it by treating an adult like a child." Dr. Reynolds also found corporal punishment misguided, emphasizing that "the inmates already suffer from low self-esteem."

Are boredom and terror, however, obviously more appropriate or beneficial than physical pain and shame, two forms of punishment we have "outgrown?" Is it more humane, more constructive to inflict psychological torture? Officially we treat the body of the criminal as sacrosanct. ${ }^{135}$ Why treat a person's body with such reverence, whose very own hand may have slashed or destroyed an innocent victim? Historically, corporal punishments have ranged from the most sadistic tortures to whipping and hard labor. Latent forms of corporal punishment, however, continue to include hard beds, cold showers, rotten food, stifling hot dorms, and insufficient medical care. Any punishment that acts directly upon the body is corporal. These latter, however, are "accidental" byproducts of budgetary constraints, and not publicly articulated policy. By default, fear and boredom have become the administration's principal weapons, available only as long as it does not acknowledge them as official policy.

The ratifiers of the United States Constitution accepted whipping as a routine and legitimate form of punishment. ${ }^{136}$ A series of Supreme Court decisions, however, casts doubt on the constitutionality of corporal punishment. It appears a judge may not sentence a convicted criminal to be whipped, but wardens retain greater latitude to implement corpo-

135. In fact, backroom "counseling"-the officers' euphemism for corporal punishment -is employed as a last resort to alter a prisoner's unacceptable behavior inside prison.

136. See note 15 supra. The First Congress enacted An Act for the Punishment of certain Crimes against the United States, \$ 16, I Stat. 112, 116 (1790), which provided that persons convicted of certain theft offenses "be publicly whipped, not exceeding thirty-nine stripes." Of course, historical practice may not be determinative on issues of constitutional interpretation. See Marsh v. Chambers, 463 U.S. 783, 814 \& n.30 (Brennan, J., dissenting) (citing the Act as a "skeleton in the congressional closet" and arguing that neither original intent nor historical practice is determinative in constitutional interpretation). 
ral punishment inside the prison. ${ }^{137}$ If original intent is persuasive in constitutional interpretation, then decisions limiting corporal punishment are erroneous. ${ }^{138}$ The retributivist, moreover, thinks the Supreme Court's decisions are wrong because corporal punishment does not offend standards of decency: Such punishment is not cruel because it is deserved. Offensive is a lack of corporal punishment in a system in which unrepentant murderers live an easy life of watching TV and getting high. The retributivist finds it ironic that while courts may declare corporal punishment unconstitutionally "cruel and unusual," they tolerate "by default rather than by design," subjecting defenseless minor felons, who have committed nonviolent crimes, to an environment inside Lorton Central where they are routinely preyed upon by armed, violent criminals. ${ }^{139}$ The retributivist also finds it ironic that we are willing to alter the mind-the personality and identity-of the criminal against his will, with psychotropic drugs, ${ }^{140}$ but are unwilling to violate his bodily integrity.

Confronted with Lorton Central's obvious failure, a retributivist may well urge corporal punishment under tight controls, but only for a criminal who has himself intentionally inflicted physical pain in the course of his crime. This includes not only the armed robber, but those business executives who subject their employees to hazardous working conditions. A retributivist insists that their bodies, too, should be

137. Although it has rarely interfered with legislative determinations of the appropriate penalty, especially in noncapital cases, in 1978 the Court stated that punishment that "transgresses today's 'broad and idealistic concepts of dignity, civilized standards, humanity, and decency" " offends the eighth amendment. Hutto v. Finney, 437 U.S. 678, 685 (1978) (quoting Estelle v. Gambel, 429 U.S. 97, 102 (1976)). In 1983 the Court found that sentencing a nonviolent but recidivist felon to life-without-parole was unconstitutional, declaring that the eighth amendment embodied English traditions that punishment "should not be, by reason of its excessive length or severity, greatly disproportionate to the offense charged." Solem v. Helm, 463 U.S. 277, 285 (1983) (emphasis added) (quoting Richard H.L. Perry, Sources of Our Liberties 236 (1959)). Although it has hinted it might, the Court has never held corporal punishment per se unconstitutional.

In cases involving prison administration, the Court has upheld abridging prisoners' first and fourteenth amendment rights only when there is a valid penological purpose served and it is not an "exaggerated response." Turner v. Safley, 482 U.S. 78, 87 (1987). Although retribution is a valid purpose, and prison officers may use force against prisoners who pose an immediate threat, it is unsettled whether they may use force against a prisoner for crimes committed prior to prison, or while inside, when that prisoner poses no such threat.

138. See note 136 supra and accompanying text. While adherents of original intent are not necessarily also retributivists, they do have a deep psychological and philosophical affinity. Whether interpreting the United States Constitution or justifying punishment, the adherent of original intent and the retributivist share a common emphasis on the past as a basis for future behavior. The adherent of original intent insists that good public policy choices yield to a constitutional mandate fixed in the past. The retributivist insists that social benefits from a criminal's future transformation yield to the justice of imposing pain for his past transgression.

139. G. NEwmaN, supra note 16, at 6. "Unfortunately, humiliation and terror in prisons occur by default not by design and therefore subject all inmates to such punishments regardless of their crimes." Id. at 8.

140. Washington v. Harper, 58 U.S.L.W. 4249 (U.S. Feb. 27, 1990); Zinermon v. Burch, 58 U.S.L.W. 4223 (U.S. Feb. 27, 1990). 
treated with the same lack of concern they have displayed toward others. These "white collar" criminals-perhaps "red collar" criminal is more apt-rarely found inside Central, should be assigned to clean up toxic wastes. They should be exposed to the kinds of hazards to which they so willingly exposed their employees and other victims.

Although no social benefits follow, a retributivist may still urge corporal punishment, but perhaps only for those who inflict pointless pain on their victims. Dr. Owen Renik, a psychoanalyst, challenges this notion. "Nobody ever hurt anyone else gratuitously. He had a reason which was real to him. We cannot separate gratuitous from nongratuitous violence. That distinction does not exist in nature." If it does, Dr. Renik later added, we in society are unable to discern it.

Nevertheless, interviews with prisoners inside Central have revealed distinguishable types: One inmate revealed how "for no reason" he decided to pistol whip a cab driver who had already surrendered his wallet and was now lying face down, unable to identify him. ${ }^{141}$ A retributivist insists that he deserves to experience pain and associate it with the physical suffering he inflicted on his victim. Then there is the robber like Johnny, who threatens with a loaded gun, willing to use it only when necessary, and never on a compliant victim. Retributively, this type of criminal deserves to be threatened with violence, which would only be employed if necessary.

"Never no violence," said Reggie Brooks, a different kind of criminal. "I was a pretty good hustler, could play cards, could talk pretty good. But never no violence. I mean if I couldn't finesse it, then I didn't want it." This criminal should be protected from violence inside Central. For him, a retributivist might argue, Central appropriately consists of mind games in which the administration creates false expectations about privileges.

In order to meet the demands and limits of retribution, punishment must be kept proportionate to the gravity of the crime. Thus, Central should be converted to a maximum security facility with controlled movement to prevent serious felons from freely roaming around and enjoying life inside, and nonserious felons from being preyed upon.

Inmate Danny Bethel declared it "time for the young dudes to recognize that this is no playground or recreational center. They should recognize that this is a place where you do hard time. This is a place where you come and it deprives you of things you once loved, the things you once cherished. It should make you want for better things. This place should be more disciplined." The retributivist agrees. And for the most vicious criminals prison should be intensely uncomfortable, with close confinement, minimal exercise, cold showers, hard beds,

141. Actually, the pistol whipping was doubly gratuitous, the robber's partner having first talked him out of shooting the helpless victim. The incident ended when the gun accidentally discharged as the cabby was being struck, shooting the assailant himself in the leg. 
the barest subsistence required by the Constitution. Prison should subject these most heinous criminals to what they subjected society, insists the retributivist. In short, for them, Lorton Central should become as Danny Bethel characterized it, "a total fear factor."

\section{F. An Integrativist}

An integrativist, who believes that no single traditional perspective has a monopoly on the truth, also recognizes that almost certainly there exists no single best integration. Either there are many just, workable blends, or none at all.

\section{Inside an integrativist psyche.}

To propose a particular blueprint is to impose one's own values. A former prosecutor and criminal law professor, I first entered Lorton Central, a furious citizen and long-time classroom advocate of retribution, curious to probe the minds of those who prey on us. Four years later, I am still angry, but now ambivalent. Ambivalence, I suspect, is necessary for an integrative perspective. In his powerful attack, The Crime of Punishment, Dr. Karl Menninger claims that "most citizens are either too close to crime and criminals to be objective or else too far from them to be aroused." 142

We must experience the criminals' humanity, and their vitality. We must feel their anguish, many of them twisted souls with tortured pasts, the products of a criminal environment that has engulfed them since infancy. Only then can we be moved to provide them an opportunity, for many their first opportunity, to become themselves, to find their potential, and participate constructively in society. Those of us who have had no involvement with inner city street life-save perhaps as a crime victim-who have never set foot inside a prison, may yet instinctively feel some compassion. But I could not, and I suspect for many others like me, it is impossible to view these criminals as other than evil, ugly cancers on society.

Our sustained face-to-face interaction, emotional outpourings from intelligent, sensitive human beings, only a small fraction of which are reflected in these printed pages, helped me, and I hope will help other angry retributivists to understand that these prisoners are human beings.

Another experience is necessary, I am convinced, for a balanced approach to punishment. Privy to the thoughts and feelings of vicious, callous predators, I cannot help but hate their crimes and feel satisfied by their punishment-feel satisfied that justice is done when these criminals suffer in proportion to their evil, selfish choices. This satisfying experience at their pain is real and I suspect necessary for a retribu-

142. K. MENNINGER, supra note 119 , at 150 . 
tivist. ${ }^{143}$ It is also, I believe, impossible for many rehabilitationists to experience it.

Rehabilitationists may insist the problem with retribution lies in the minds of retributivists no less than in the criminal, both of whom are troubled souls who would express their anger by violence or torture. Dr. Menninger points out our common lust for domination and violence, channeled in work, sport, art, television, displaced in hunting or cheering ringside at a boxing match. In a thousand ways we constructively channel this impulse we all possess. For many of us, such displacement includes our vicarious pleasure at the pain of the criminal bungler who happens to have been caught.

In his excoriating denunciation of prison and prison advocates, Menninger observes:

We need criminals to identify ourselves with, to secretly envy, and to stoutly punish. Criminals represent our alter egos-our "bad" selves-rejected and projected. They do for us the forbidden, illegal things we wish to do and, like scapegoats of old, they bear the burdens of our displaced guilt and punishment ....

... Our submerged hates and suppressed aggressions, our fantasized crimes, our feelings of need for punishment-all these can be managed in part by the scapegoat device. ${ }^{144}$

We call it a wish to see justice done, i.e., to have him "punished." But in the last analysis this turns out to be a thin cloak for vengeful feelings directed against a legitimized object. ...

This sentiment of retaliation is, of course, exactly what impels most offenders to do what they do.... [They] are usually out to avenge a wrong, assuage a sense of injury, or correct an injustice as they see it. ${ }^{145}$

So, according to Dr. Menninger, we have met the enemy and they are us, or at least no different from us. Dr. Menninger concluded his sustained and passionate critique declaring that "before we can diminish our sufferings from the ill-controlled aggressive assaults of fellow citizens, we must renounce the philosophy of punishment, the obsolete, vengeful penal attitude.... This is the message of old religions and new psychiatries."146

Four years ago I would have scoffed at the thought that the problem of punishment could lie with the psyches of those urging it rather than

143. "Abstract punishments," measured in units of time, "separate us from the concrete fact of retribution, the concrete fact being that we must feel that punishment has been done. When corporal punishment is used, there will be no doubt about our feeling that punishment has been done, because everyone has at some time in their lives experienced such pain." G. NewMan, supra note 16 , at 37 .

144. K. MENNINGER, supra note 119 , at 153-54.

145. Id. at 190.

146. Id. at 280. 
with those deserving it. But now I am not so sure. Was Menninger correct? The literature on this is sparse. But to search for and find an appropriate blend, to weigh priorities among competing concepts, we must understand what it is for a retributivist to be satisfied.

"The problem with this kind of analysis, which sees the criminal as a projection of your own bad self, is to confuse thought with action," declared Dr. William Weiss to me. "We all have violent wishes or fantasies that are more or less available to consciousness. But they're fantasies-they're in the realm of thought. To see all criminal activity as the product of fantasy overlooks the reality that some people do acts which are very destructive. Whether it's unconscious murderous impulses or conscious sadistic feelings of which you may be aware and disapprove, everybody has within them some conflicts around their own aggression. But to say that punishment is merely the expression of people's needs to have a scapegoat, to project their fantasies of getting rid of their own bad selves, is a simplification and a distortion. Just as the motives for criminal behavior are very complex, so too are the motives for responding to criminal behavior. There are people who are trying to punish others to deny within themselves that they have similar kinds of feelings or impulses. But that's not what all retributivists are about. You or I, for example, think there's a social purpose to be served by it."

"No!" I protested, comfortably arguing the retributivist case. "Pure retributivism calls for pain and suffering because it's deserved even if it does no good. It doesn't change the criminal; it doesn't reduce crime. It doesn't do anything other than serve justice."

"But justice is a social concept."

"No. It's this feeling - which you identify as infantile perhaps, or primitive. He inflicted gratuitous pain and suffering; therefore he deserves to experience pain and suffering. The past cries out for it. It restores some balance to the universe. No other social benefits in the future. It feels right. This feeling of justice; this is what pure retributivism is about."

"You're talking about it in an abstract and somewhat philosophical way," Dr. Weiss replied. "That sense of 'deserve' implies a broader context than just the individual. You can't get those concepts-'deserving, justice'-without embracing that part of the human psyche which is geared towards social adjustment. A sense of justice is an abstract concept that reflects a well-developed superego. So that you may develop quite an abstract sense that justice demands that a person suffer corporal punishment. If you injure me and I want to see you punished, that is partly because you have done something which takes away from my sense of well-being in some very basic way. You have diminished me by showing me to be vulnerable, by having destroyed or damaged some very deep seated sense of my own importance or omnipotence." 
"Or scarred your face, or broken your spine."

"Those are all narcissistic interests of a basic sort. Your body is your first repository of your sense of self-love. But the position as an observer becomes more complex from a psychological point of view. An observer at best empathizes with what the victim has undergone. You want to prevent that from happening to yourself and therefore wish to see retribution done. I think the only pure retributivists are those who have had the damage inflicted on themselves. Otherwise, some more complex psychological interaction has got to be going on if you see this happening and think a person ought to be suffering. There's got to be some sort of abstract social conscience."

"It's not abstract," I insisted, remembering a particular criminal at Lorton Central: "The burglar who grabs the children leaving for school, takes them back into the house, ties their father to a chair, and with a gun to his head, makes the husband watch the rape of his wife ${ }^{147}$ - I want him to suffer every day of his life. Not because I think it's going to do any good. Not because I think it's going to change his behavior. But because my feeling of justice is satisfied-not completely-but it comes closest to being satisfied, if he suffers. What would you say of a person who feels that way?"

"One might say that he has an overconcern about the need to punish people for these particular crimes, because of some overinvestment in, some overconcern about the likelihood of such things happening, which may be related to distancing himself from a part of himself that might be interested in doing that. This is called 'reaction formation,' where a person consciously takes an attitude which is the exact opposite of that which one wishes unconsciously."

"Then Menninger is correct: Our retributivism gives us a legitimate outlet for doing the very thing we condemn," I answered, disappointed that both psychiatrists seemed to agree.

"Yes, there is a sadistic element in this. There would have to be."

"So we're no different from the criminal we hate."

"Yes you are."

"Only because we've restrained ourselves?"

"That's a big difference. That's all the difference in the world. In our dreams, where our unconsciouses are more available to us, often there's quite a bit of mayhem. Our wishes are lived out in them, either directly, or in a more disguised form. Say you're listening to a boring lecture. I've had the fantasy of shooting the lecturer or throwing a hand grenade. That type of inner experience is relatively common. I think it's universal unless you're very repressed. But you don't get a gun and shoot the lecturer. To say that having a fantasy of killing the

147. See text preceding note 128 supra. 
lecturer makes us equivalent to somebody who takes out a gun or stabs him to get his wallet, is just wrong."

"But then we have no right to condemn him for his impulses. I want to distance myself morally from that person."

"People who act on their impulses have in some ways a very different psychological structure from people who restrain themselves."

"But a pure retributivist will also act on his impulse to hurt, at least once it's legitimized. ${ }^{148}$ The criminal should suffer. He should understand why he suffers. He must be made to regret what he did!"

"It's not difficult to make him feel regret," said Dr. Weiss. "You can inflict a physical injury on somebody and humiliate him. You can cut off their hand, and really limit their capacity to be whole. Such a person may feel bad and say 'How could I have gotten myself into this. It's too bad I did this. I made a mistake.' He will feel regret. And he will probably feel very angry. He will not, however, feel guilty. Regret is very different from remorse. Remorse is very closely associated with guilt. Remorse is feeling bad in some way because of the impact your conduct has had on some other person."

"How can we make him feel remorse?" I asked Dr. Weiss, unsure if it was a retributivist or a rehabilitationist asking. ${ }^{149}$

"A person who can't feel guilt has to be subjected ... no, invited to participate in a variety of interpersonal experiences that might help them to develop a superego, which means socializing them. Part of the impulse to punish-to see justice done-comes from the capacity to empathize with the suffering of a person to whom an injustice is done. The people who do the injustice often lack that very capacity to empathize. The person who robs you and then kills you for kicks is a very rare phenomenon. Such people have reached adulthood with this particular deformity or defect in their character where they don't empathize. They can't have the feeling 'Well I shouldn't kill somebody because it's a bad thing-I wouldn't want to be killed.' They don't have that. And that is one of the most difficult things in psychiatry to treat. It can be treated in some cases under favorable circumstances, and special conditions."

148. It is ironic that a pure retributivist who rejects the analytic retributivist's justification for punishment, because of its emphasis on the legal definition and proof of crime, is happy to distinguish his own from the criminal's revenge on the basis of law.

149. It might appear that producing emotions of regret, remorse, or guilt in a criminal should be the sole concern of a rehabilitationist, unless the criminal happened to have intentionally produced those very emotions in his victim. But this is to restrict retribution merely to a measure of punishment. Remorse, as a painful experience produced through punishment, is very much in the domain of the retributivist, who, above all, emphasizes the independent claim of the past on our future behavior. How appropriate, therefore, that the past behavior of the criminal not only justifies imposing pain on him, but also that the past itself and his attitude toward it should be the very source and object of his painful feeling. Of course, a prisoner's remorse is also very much the concern of a rehabilitationist as an instrument towards his reformation, and this common objective-the criminal's remorse-may reveal common ground between these antagonists. 
"How?"

"It's very, very difficult to change that in an adult. I've treated some people like that, but I've never changed it. You put them in a setting, in a therapeutic environment where certain kinds of pro-social behaviors are reinforced; certain kinds of anti-social behaviors are limited-not sadistically punished but limited. They suffer certain consequences for their behavior. There's a kind of behavioral element to it. Besides, that kind of thing is inconsistent with being inside a prison."

"If we make them suffer in the same way they made their victim suffer, then they'll empathize," the retributivist in me declared.

"But that's not how they'll experience it. They're experiencing it as 'I got caught and you've got the upper hand.' People with that kind of character problem, who really aren't able to empathize with what another person feels, think that everybody thinks the way they do. So they treat other people as objects to be manipulated and exploited. And they're going to do it to you to get one over on you. They probably think that you're doing the same thing to them. They wouldn't understand the broader meaning."

"What about the rehabilitationist?" I asked the doctor. "The pure rehabilitationist who wants no punishment-who is entirely future oriented, entirely forgiving, wants only to help the individual criminal?"

"Such persons are probably very uncomfortable with their own sadism, probably denying it and covering it up. Acting as if it doesn't exist."

"So both retributivists and rehabilitationists are very uncomfortable with their own sadism ultimately?"

"The retributivist is more comfortable with it. He's getting pleasure out of seeing the criminal suffer. That's pretty direct."

"Not always," I insisted. "There's a limiting aspect to pure retributivism. People should not suffer disproportionately to what they deserve. That the people who are committing the least serious crimes inside Lorton Central are suffering the most offends me deeply. That the people who are committing the most serious crimes are suffering the least also offends me. Equally and oppositely. Perhaps the retributivist is not sadistic, after all," I said hopefully.

Dr. Weiss looked bemused. "This is a very highly refined way of processing a person's sadism: It's sublimated. It's a very sublimated form of sadism."

"So it is sadism."

"Yes, but sublimated sadism is not mere sadism. It's sublimated sadism. The same way that Rembrandt isn't smearing feces on the floor."

There were other avenues to explore but they seemed too far removed from Lorton Central Prison, and besides, the psychiatrist was looking at his watch which meant that for now the session was over, as 
is this brief and admittedly far from complete attempt at a psychodynamic understanding of retributivists or rehabilitationists.

\section{Reconciling rehabilitation and retribution.}

This integrativist returns to the assumption which has been the principal foundation of this study inside Lorton Central: The obstacle to a workable system of punishment lies not with the minds of the advocates of punishment but with the experience of the prisoners, as comprehended under the philosophies of the critics. In their search for a common goal-justice-differently defined, somehow the retributivist and rehabilitationist must be reconciled.

Whether or not there is a common psychological source, ${ }^{150}$ perhaps there is common ground in their philosophies, on which to erect a coherent system of punishment. Traditionally, a retributivist blames the criminal for his freely willed harmful act, whereas a rehabilitationist sees the individual criminal as determined by factors outside his control. In its earliest American form, however, retribution was based on a deterministic assumption that criminals were born evil, while, as we have seen, contemporary wisdom inside and outside Lorton Central is that true rehabilitation can only be voluntary, resting on a criminal's choice to change.

Nonetheless, in designing and implementing punishment, reconciliation is difficult. Should officers treat the inmates as objects of correction, or of punishment, or as fellow travellers, beset with common problems in this difficult world, for whom some larger impersonal system has cast in different roles? No single attitude seems to satisfy at the same time the retributivist and rehabilitationist. They may disagree, then, whether officers should be angered by the criminal's past, but they agree that officers should not be ignorant of it. They should also agree that a prisoner's punishment is not measured primarily by the number of years spent inside the joint, but daily, in the experience of the time served. If the seriousness of the past crime is completely severed from the experience inside the prison, then expiation is not possible, atonement is unreachable. A retributivist officer angrily inflicts pain and suffering to bring the past crime back to the mind of the criminal and force him to regret it. The officer who would rehabilitate also tries to alter the criminal's mind so he will regret his crime and its consequences for himself, his family, and his victim.

To do justice, then, requires first that the criminal connect his crime with his punishment. But as Dr. Weiss observed, if the criminal's regret is merely anger at his own stupidity or bad luck, or resignation at this latest in a never-ending series of abuses to which he has grown accus-

150. As Herbert Packer observed, whether we think of crime as evidence of depravity or pathology, "[w]ho can be sure that the urge to punish and the urge to cure may not have a common source in some dark recess of the human psyche?" H. PACKER, supra note 10, at 60. 
tomed since childhood, neither retribution nor rehabilitation have taken place. More is required. The analytic retributivist requires the prisoner be found guilty before we begin to punish him. But the pure retributivist demands he feel guilty before we finish punishing him. ${ }^{151}$ Remorse requires the criminal feel pain at having inflicted pain on other people.

Itchy was on to something when he insisted, "Maybe I got a value system when I came in where I didn't know that I owed you. You got to make me know that I owe you something."

Full retribution, full pain, must act not only on the body of the criminal but on his soul. It must act not only to produce regret, but remorse. And to produce full remorse a prisoner must have a value system by which he too comes to hate what he did, to hate who he was.

The pure retributivist, however, would mercilessly continue to inflict pain and suffering upon a reformed person-should any exist-but in a manner he will feel even more deeply. The criminal would be shown his suffering victims: a parent, visiting the grave of a murdered child, a permanently traumatized rape victim. Emotionally the criminal would be made to understand and feel the full effect of his transgression, in a way that will cause his greatest suffering.

The acquisition of that value system necessary for full retribution, however, is pure rehabilitation. The same value system necessary for the criminal to feel the pain is also necessary for him to participate actively in social life, not from fear, but from a desire to join the community of humane beings. The remorse that pure retributivists need to produce in a criminal in order to be satisfied, long after it is produced,

151. In his Criminality from a sense of Guill, Freud identified criminals in whom "Ip]aradoxical as it may sound, I must maintain that the sense of guilt was present before the misdeed, that it did not arise from it, but conversely-the misdeed arose from the sense of guilt." S. FREUD, supra note 68 , at 332. This confounds the retributivist. For, as Freud asserts:

With children, it is easy to observe that they are often "naughty" on purpose to provoke punishment, and are quiet and contented after they have been punished. Later analytic investigation can often put us on the track of the guilty feeling which induced them to seek punishment. Among adult criminals we must no doubt except those who commit crimes without any sense of guilt, who have either developed no moral inhibitions or who, in their conflict with society, consider themselves justified in their action. But as regards the majority of other criminals, those for whom punitive measures are really designed, such a motivation for crime might very well be taken into consideration; it might throw light on some obscure points in the psychology of the criminal, and furnish punishment with a new psychological basis.

Id. at 333. The retributivist cannot very well seek guilt as the product of punishment for those who seek punishment to assuage their feeling of guilt. Nor of course can prison deter them. The incapacitationist would restrain this type of criminal and the rehabilitationist would treat this sick, unpunishable person. Perhaps after such treatment, having eradicated the original source of guilt, the retributivist would then insist that the criminal acquire a new sense of guilt stemming from effects he has actually produced on the victim of his crime. But the new source of guilt may drive the criminal to new crime, creating a vicious circle. If Freud is correct and this criminal type is very common, then what remains of retributivism? I suspect, however, that Freud's criminal whthout a sense of guilt is more the norm inside Lorton Central. 
may eventually reverberate in the retributivists themselves, who at last realize that they too are now imposing gratuitous pain and suffering on a fellow human being whose humanity even they can see. Once retributivists understand that by continuing to make a remorseful being suffer, we are needlessly adding to the storehouse of human suffering, then they too may feel remorse, and say "Enough! We have punished each other enough."

If these apparent antitheses can be philosophically and psychologically reconciled for the criminal and the advocate, should they not be similarly reconcilable in a workable system of punishment?

\section{Common ground.}

The literature is voluminous as to the conflicts among the concepts of retribution, incapacitation, deterrence, and rehabilitation. ${ }^{152}$ And we saw many conflicts between these concepts played out inside Central. For example, a retributivist might be pleased if a prisoner's access to family were cut off or reduced. That is pain he will feel. A convict, once released from Central, might be specifically deterred by the painful memories of being denied access to his loved ones, but only if he has come to value, or continues to value, that family connection. Yet if close family ties are necessary for rehabilitation, prolonged separation might loosen or cut them forever. And then again family pressures may drive a parolee back to prison. Some proposed changes, however, may rest on common ground. Controlled movement and a 24-hour guard presence in the dormitories pleases the incapacitationist because fewer crimes are committed on the inside. It pleases the retributivist: Predators who now control the prison are penalized when their freedom to hustle and to hit is constricted, while controlled movement protects the less culpable against unwarranted suffering. Advocates of deterrence are also pleased by a prison environment which more restricts a prisoner's freedom because memories and images of the joint down the road will seem less sweet to past and future convicts. The more a prisoner's deserved pain and suffering is actually experienced, and known by others, the more retributive and the greater deterrent is that punishment. ${ }^{153}$ Controlled movement and a constant presence of officers in the dorms pleases the rehabilitationist. A more structured and secure environment will force the inmates to learn trades, get an education, and focus on themselves and what brought them to prison.

152. "Probably the most frequently contemplated topic in the entire field of penological theory is the functional incompatibility of such ends as, for example, retribution and therapy," declared Johan Galtung in Prison: The Organizational Dilemma, in The Prison 122-23 (D. Cressy ed. 1961); see also The American Correctional Association Manual of Correctional. STANDARDS 7 (3d ed. 1966) (stating that "in practice the two theories run counter to each other at so many points," and that "[t]he debate on the punitive versus the rehabilitative theory has filled the pages of penological literature for generations").

153. The obvious interdependence between general deterrence and retribution has been recognized in the literature. A. VON Hirsch, supra note 10, at 52. 
Similarly, material deprivation inside the prison which a retributivist urges, because the prisoner deserves to be stripped of material comforts, also appeals to deterrence advocates because it will pressure excons and future criminals, for whom "it ain't about doing without." Incapacitationists would happily remove jewelry, expensive shoes, stereos and other objects of theft from the prison.

The rehabilitationist, too, should agree. Many lower-level drug dealers, thieves, and robbers grew up in communities where status and success are measured by a display of wealth. These prisoners, once released, will return to a society where lawful opportunities for employment are few and wages are low. The rehabilitationist seeks to teach the inmates to value that which they seemingly despised as insignificant compared to material acquisition-freedom and simple comforts. Watching a ball game, snacking on potato chips is a simple pleasure, cherished alike by rich and poor in the "free" world. Reading a newspaper, lying in bed switching channels, watching late night TV, listening to tapes on a stereo, going to a gym to work out, are, in the free world, legal pleasures, longed-for respites from pressure and responsibilities. Out of compassion or to pacify them, the administration has readily supplied the inmates these same inexpensive comforts. Inside Lorton, where "the days are yours and the nights are yours," they are taken for granted by prisoners as their daily due. Thus, upon release, the ex-convict devalues them, never having lost them, and seeks instead more of what only the street can offer. Rehabilitation must consist in teaching them to appreciate life's simpler pleasures and to live happily thereafter without the glitter.

The retributivist is appalled that so many younger prisoners seem content. But rehabilitationist-oriented prisoners are also unhappy at this. "When you're here you're supposed to be miserable; that's what this place was built for," said Itchy.

"Should it be built for that?" I asked.

"If it's not miserable to a person, then a person won't gain anything by being here."

"More discipline" would be a "good thing," Pete Arnold declared. "When a guy is in a cell 23 hours a day, it wakes him up to what's important in the world. He runs an excellent chance of getting in touch with himself. It makes him see a different world when he's locked up because the things he turns to for entertainment must change. Being locked up cuts the bullshit; it makes you face the real picture-your reflection. You begin to go inside yourself and think back to some of the things that you don't normally have time to stop and think. When you're in the street, you're ripping and running. But when you stop, you think back about things that you're doing, things you haven't done, things you should have done."

There may even be common ground about physical pain and suffer- 
ing. Reggie Brooks criticized the present crop of black officers: "The brothers come in and they don't have no more ability to produce rehabilitated people than that white administration had twenty years ago, and probably even less because they cannot be oppressive."

Traditionally, retribution and rehabilitation have clashed irreconcilably over the nature of sentence lengths. Retributivists demanded "fixed" sentences-often ignoring the variability of the living conditions inside-based solely on a prisoner's past crime and unconnected to his future conduct in prison, whereas rehabilitationists insisted on indeterminate sentences by which a prisoner is incarcerated until cured. ${ }^{154}$

But the process by which a number of years first symbolized and later became the measure of punishment has obscured the fact that in a prisoner's experience of punishment, pain and suffering are not equally distributed throughout his term. The worst part of prison is the first several months of the first "bit," and the final months before release when time drags. The first year of a first-timer's 5-year sentence is likely to be more painful than the next three years combined. Because a prisoner's daily suffering essentially consists of fearful uncertainty, an indeterminate sentence which denies a prisoner the comfort of a clear and definite target exit date, ultimately may be as painful and retributive as a fixed sentence. ${ }^{155}$

\section{A tentative sketch.}

We all seek to create a prison environment which effectively discourages a return to crime and prison. For the last half century we have been convinced that "the correct choice of punishment ... usually consists in a wise blending of the deterrent and reformative, with the retributive well in mind." 156 We advocates of a composite view embrace as "nearest the truth" a philosophy in which "there must be an element of retribution or expiation in punishment: but that so long as that element is there, and enough of it is there, there is everything to be said for giving the punishment the shape that is most likely to deter and

154. "Indeterminate and semi-indeterminate sentences are the logical extension of the rehabilitative philosophy. Indeed the terms are synonymous." P. BEAN, supra note 7, at 156.

155. "Indeterminate sentencing creates a situation of misery for inmates who are forced to suffer through the uncertainty of not knowing the time of their release." A. VON HiRsCH, supra note 10, at 31. Gardner, supra note 10 , at 787, uses this observation as a reason to abolish indeterminate sentences as inconsistent with a "just deserts" philosophy. Alfred Hassler observed "It is the uncertainty that creates the tension. If I knew that I must stay here for a specified period, even my whole sentence, I could settle down to it with more equanimity than I now feel." R.A. HASsLER, supra note 51 , at 144 . To cherish each day as if it were your last makes a free life more pleasurable, but in prison to suffer each day, hoping it is your last, makes life more painful.

156. F.J.O. Coddington, Problems of Punishment, 46 Proc. Aristotelian Soc'y (n.s.) 155 (1946), quoted in J. HALL, R. Force \& B.J. GeORGE, supra note 10, at 182. 
reform."157 As students of Lorton Central, we discovered that it may not be possible to simultaneously embrace retribution, deterrence, rehabilitation, and incapacitation. Searching for a composite experience then, I offer a tentative sketch, ultimately more a patchwork than a blend of layered punishments, differentiated by the crime committed, sequentially experienced to permit different concepts to receive emphasis as the prisoner progresses through his punishment.

A criminal convicted of a serious, violent offense should be isolated from all contact with other criminals. During this initial phase, he should be subjected to a diagnostic evaluation, which will help ascertain his drug dependence, educational level, and special needs. Aggressive interviewing should help determine his hostility level, bearing in mind that contrition can be faked. After the initial diagnosis, convicts should be separated into groups according to the seriousness of the crime committed. For the entire duration of their sentences, they should live among others who committed crimes of equal seriousness. These classes of criminals are the layers, and the quality of life of each layer inside should always remain a function of the crime committed outside. ${ }^{158}$ Within each layer, however, inmates may progress in stages.

The first stage should be most retributive. Our goal is to impress upon the prisoner that we remain angry at his crime and will therefore cause him to suffer. From day one prisoners should be separated into dormitories or cell blocks and visibly marked in their clothing according to the nature of the crime committed. Drug addicts who are murderers would be forced to dry out, cold turkey, whereas those who committed the least serious crimes would be eased from their dependency, as painlessly as possible. A prisoner who has committed gratuitously violent crimes should be subjected to corporal punishment by officers who remind him of the connection between his senseless infliction of pain on others and his own present pain. Neither visitors nor televisions shall be allowed to diminish the pain of this first phase of punishment. The attitude of the guards should be stern, and professionally hostile.

After a period of atonement, whose length depends upon the nature of the crime, assuming the prisoner has caused no trouble, we begin to show him that we are not only angry at his past conduct, but also that we care about his future development and will offer him meaningful opportunities for self-improvement. At the beginning of this second

157. Lord Justice Asquith, The Problem of Punishment, 43 THE LISTENER 821 (1950), cited in J. HALL, sufra note 8 , at 304 n.26.

158. "[W]e can attain a more flexible system by developing a variety of organizational structures and climates within the confines of a single institutional setting." R.I. Weiner, Management Stralegies to Reduce Stress in Prison: Humanizing Correclional Environments, in THE PaINS of Imprisonment 304 (R. Johnson \& H. Toch eds. 1982), cited in R. Johnson, supra note 26, at 167. 
phase, we invite him to join in designing a long-term plan for his rehabilitation. What skills does he want to acquire? Priority among programs in great demand is determined by the prisoner's layer-i.e., the crime he committed. If the inmate refuses to cooperate, he stays in phase one, isolated, maximally deprived of freedom, until or unless he changes his mind. During this second phase, while a long-term plan is being designed and its implementation begins, we give the prisoner mixed signals. Retribution is decreased but not eliminated. Corporal punishment, where initially appropriate, continues but is diminished, and every inmate is continually reminded of his crime and its connection to his punishment.

The correctional staff must be a physical presence in the inmate's life 24 hours a day. Thus, the prisoner will feel deprived of freedom and privacy which he will come to appreciate and value. His overall opportunity to commit crimes will have been diminished, and in later stages, the officer presence will provide an opportunity for counseling, as well. Although different layers will be treated differently as to phone privileges and living conditions in general, essentially, as we try to inculcate work habits, and a structured week, every inmate is to work or be at school, from 14 hours a day, 7 days a week, to 10 hours a day, 5 days a week, depending upon the layer. Every inmate must do some hard time, and every inmate must labor, although he may not be forced to acquire skills. If necessary, an inmate's day should be spent digging holes and filling them up. If the prisoner shows no progress toward rehabilitation-and even faking should be considered some progresshe stays in this phase, unless he commits crimes on the inside. In that case he moves back a phase, or is transferred to another layer, the bottom one of which altogether rejects rehabilitative programs.

From here on, an inmate may progress and feel his progress. Educational and vocational achievements are rewarded with additional privileges such as visiting, canteen items, hourly wage increases-always qualified, however, by the layer of punishment as determined by the crime committed. Each inmate should be encouraged to save a substantial percentage of monies earned. Some of those savings will go toward the upkeep of the victim's family, and the remainder should be kept in an interest-bearing account for the benefit of the inmate's family or the inmate, once released. The Department should match the savings at some ratio-again a function of the crime committed-so the inmate builds a stake in working, saving, and has resources on which to draw, upon release. After phase one, family ties should be encouraged yet limited, to develop in the inmate a sense of connection but also deprivation in not being on the outside. At first, visits should be noncontact and brief. As the inmate progresses, privileges may be extended. But again, visiting restrictions should always be somewhat related to the severity of the crime committed. Retributivism demands 
that although the prison experience becomes less painful, it remains relatively proportioned to the crime which occasioned it.

After a period of achievement, the prisoner moves to a less punitive dormitory. His prison garb changes to clearly mark his phase of development, but it always includes a color stripe to mark his crime. The attitude of the staff changes in phase three as they engage the inmate in more friendly conversation, and are more ready to help him. He is given greater free time, and more privileges. But for purposes of deterrence and to satisfy the retributivist, at some regular interval he is made to suffer-if only by a cold shower-as he is reminded of his past transgression. In sum, the inmate should suffer, the suffering should be continually connected in his mind to the crimes he committed, and the suffering should be as constructive as possible.

Unless we are to reconstruct Dante's hell, the prisoner must have hope. At least once every ten years, every inmate's case should be thoroughly reviewed. Recognizing difficulties inherent in definition and determination, with the exception of the most heinous criminals, any inmate who has significantly turned his life around should have a substantial prospect of release. A prisoner, however, should not be released as soon as he is believed rehabilitated. He must serve a sentence long enough to satisfy moderate retributivists. On the other hand, good time should be given, not simply for staying out of trouble, but for vocational and other achievements relative to the inmate's potential.

As the end of an inmate's sentence approaches because he has served his time, or because we have come to be convinced that he now feels remorse, cherishes his freedom, has acquired necessary skills, and possesses some financial resources, he should again be made to suffer most intensely, to ensure that on the balance memories of prison will be overwhelmingly negative. He should be returned to live among those who are in phase one, and one layer more serious than his group. There he should feel superior to them, knowing his punishment is almost at an end, while at the same time experiencing more severely than ever the pain and suffering of deprivation. His pain, both psychic and physical, should be maximized. He must be made to understand that should he return to Lorton Central, conditions will be harsher. And in our world of scarce resources, finite compassion, and limited forgiveness, there will be no third chance. Like Shakespeare's "born devil, on whose nature nurture can never stick," on whom "pains humanely taken, all, all lost, quite lost," 159 this incorrigible criminal will face only pain and suffering. He will spend all his time inside maximally de-

159. We will deal with this repeat offender as Shakespeare's Prospero did with Caliban:

A devil, a born devil, on whose nature Nurture can never stick! on whom my pains,

Humanely taken, all, all lost, quite lost! And, as with age his body uglier grows, So

his mind cankers. I will plague them all, Even to roaring.

William Shakespeare, The Tempest, act IV, scene i (Oxford ed. 1964). 
prived of his liberty with no rehabilitative opportunities. Thus, by denying third chances, we not only retributively punish the incorrigible, but also deter the twice convicted.

In the final brief phase, without warning, as his pain reaches its greatest intensity, the inmate should be whisked to a halfway house, where the attitude of the staff and the environment is in marked contrast. Here the staff are counselors, and their sole purpose is to provide a refuge while the resident gets a job and saves some money to have a jump start back into social life. The resident sheds his stripe.

This then is a sketch of an integrative punishment. While incapacitating and hopefully offering some real deterrence, it is motivated both by a retributive anger that vicious criminals choose to rape, maim, and kill innocent people and, at the same time, an understanding that these criminals are often a product of a biological inheritance, early childhood abuse, family values, and economic deprivation-for which they are no more responsible than we, the society that failed to intervene earlier.

It would pervert the integrativist understanding to implement retribution while ignoring rehabilitative aspects of these prisoners' punishment. We must make them suffer proportionately to the gravity of their crime and their inner depravity; we must encourage and reward their achievements in prison; and we must provide them opportunity for eventual lawful integration into society.

\section{Conclusion}

Can this happen? Will this work? Doubtfully. Crime and punishment, our chronic crisis, is probably insoluble. We are trapped in categories from which we cannot escape; we are confined by the institution of confinement as punishment which fails. Condemned by our criminals to fear in the streets and frustration with our prisons, through studies and reform, we must continue the uphill struggle-for their sake and ours-and like Sisyphus deluded, advance our burden ever so slightly before it crushes us with the next new understanding.

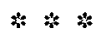

\section{EPILOGUE}

Itchy Brooks has been transferred to the federal penitentiary at Leavenworth. Several prisoners quoted in this study, including Reggie Brooks and Henry Daniel, have been moved to distant facilities leased by the D.C. Department of Corrections. Administrator David Roach has been transferred from Lorton Central and is currently Administrator of the D.C. Jail. Walter Ridley has been promoted to Director of the D.C. Department of Corrections.

Johnny Allen was to suffer the fate so often described to him during 
our three years of interviews. He was transferred to a halfway house whose staff could not find a job for a paraplegic ex-convict. A few months later, Johnny was paroled to the streets, determined to go straight. At first he lived with his daughter, but after a while her boyfriend objected, and she asked him to leave. No one else in Johnny's family would take him, and with no money for rent, he applied to shelters, which were full or unable to accommodate him in a wheelchair.

A cocaine dealer offered his old friend Johnny one of his fifty-six apartment units, rent free, with spending money for food: "You don't have to hustle. You don't have to move any packages, but you got to accept what's going on around you. All the people staying there are doing one thing or another." But Johnny knew himself, and he knew what accepting that offer meant: "You hold, you bag, you count up." So Johnny refused, joining the ranks of the homeless: "All they can arrest me for now is vagrancy."

Awaiting admission to a shelter, he slept on a filthy mattress in a cold abandoned building, using sterno for heat, until the fire department and arson squad forced him out. He wheeled around the streets of D.C., sleeping at night sitting in his wheelchair, hugging a radiator in a hallway, or in a boiler room of an apartment building where a friend of a friend had persuaded the janitor to look the other way. Unable to lie down or bathe, hungry and hating life, Johnny desperately clung to his self-respect and his freedom, determined to keep the promise he had made to himself never to return to Lorton.

"It's so hard to be honest," Johnny sighed. "I have more remorse about the things I've done than I ever had. I don't want to add on to it; I want to make up for it. I don't want to sell the goddamn poison to our children. So here I am, one patriotic nigger, chasing the American dream. I'm free. I'm cold and I'm hungry, but I'm free. And it's killing me." 
